\title{
Selling Winners, Holding Losers: Effect on Mutual Fund Performance and Flows
}

\author{
Zhaojin $\mathrm{Xu}$ \\ Dissertation submitted to the Faculty of the \\ Virginia Polytechnic Institute and State University \\ in partial fulfillment of the requirements for the degree of
}

Doctor of Philosophy

In

Finance

Approved by:

Vijay Singal, Chair

Michael T. Cliff

Gregory B. Kadlec

Arthur J. Keown

Alexei Ovtchinnikov

May 10, 2007

Blacksburg, Virginia

Keywords: Mutual Funds, Capital Gains, Disposition Effect, Fund Flows, Fund Performance, Tax Overhang

Copyright 2007, Zhaojin Xu 


\title{
Selling Winners, Holding Losers: Effect on Mutual Fund Performance and Flows
}

\author{
Zhaojin $\mathrm{Xu}$
}

\begin{abstract}
In this dissertation, we examine whether the disposition effect, the tendency to sell winners and hold losers, exists among U.S. equity mutual funds and how the disposition effect influences fund performance and particularly flows. We find that a significant fraction (32\%) of all funds exhibit some degree of disposition behavior. These funds underperform funds that are not disposition prone by 4-6\% per year

Moreover, we find that the disposition effect has a significant impact on future fund flows. Without controlling for performance, disposition-prone funds experience 2$3 \%$ less flows each quarter than other funds. The difference in flows is probably due to poor performance of such funds. However, even after controlling for performance and other factors that potentially influence flows, funds with a high disposition effect experience $0.7-2 \%$ less flows than funds without such behavior.

Past research has found that funds with low tax overhang garner larger inflows. Though disposition-prone funds are likely to have a lower tax overhang because they sell their winners quickly, we find that fund flows to disposition-prone funds are smaller than flows to non-disposition oriented funds after controlling for tax overhang. These results suggest that performance and tax efficiency as well as tax overhang are all important to mutual fund investors.
\end{abstract}




\section{ACKNOWLEDGEMENTS}

I would like to express my sincere gratitude to my committee chair, Vijay Singal, for his meticulous guidance and valuable advice on my research, teaching and career. I am greatly indebted to him for his help, suggestions and support all through the writing of this dissertation. I am grateful for his encouragement and advice on my teaching skills and methods, and for his valuable time and effort in preparing me for the job market. Without his support and contribution, I would not be able to complete the dissertation and find a job successfully. I admire his attitude towards work and research, and respect his knowledge and professionalism. His outstanding attributes would undoubtedly play a lasting role in my career from here on.

Besides my advisor, I would like to thank the other committee members: Gregory B. Kadlec, whose work demonstrated to me a strong commitment to high quality and significant contributions. I am indebted to him for his help and invaluable comments on my research work. I am grateful to Michael T. Cliff for his very insightful comments on this work and helpful suggestions as Ph.D. director, to Alexei Ovtchinnikov for reviewing my work, and to Arthur J. Keown for his encouragement and support during the job market.

I am also grateful to the following professors who taught, helped and inspired me: Barbara Remmers, with whom I worked on my very first research project, Dilip Shome, who introduced me to the world of empirical corporate finance and was keen to work with me, Huseyin Gulen, for his great investment seminar and for always being willing to help, Raman Kumar, who answered my numerous questions on research, and John Easterwood who helped me a great deal with my teaching skills.

I also would like to thank my fellow colleagues who made this otherwise lonely

journey an enjoyable one. Specially, I thank Marius Popescu and Shu-yi Tsai for being supportive and helpful whenever I needed them. I would also like to thank my friends for their continued care. A very special thank you goes out to Kheng Swee Goh, who was always there for me, and cheered me up when I was down or stressed. 
My deepest appreciation goes out to my father Jishi Xu and my mother Nasha Li. They have given me the greatest love and unconditional support and they have always encouraged me to pursue my dreams and make many of my dreams come true. I dedicate this work to them. 


\section{TABLE OF CONTENTS}

ABSTRACT .................................................................

ACKNOWLEDGEMENTS .........................................................ii

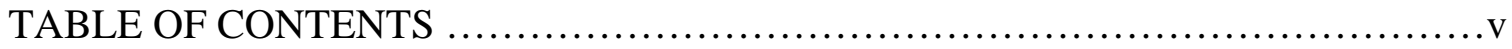

LIST OF TABLES .........................................................

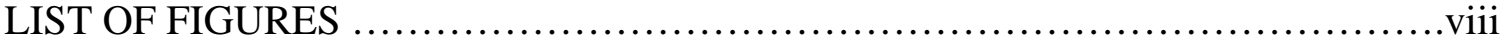

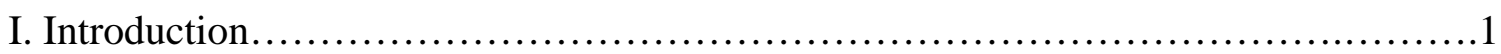

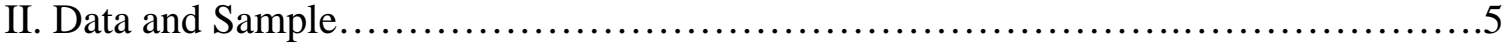

III. Estimates of the Disposition Effect..........................................

IV. Disposition Effect and Fund Performance....................................11

V. Disposition Effect and Fund Flows.........................................16

A. Without Controlling for Performance...................................17

B. Controlled for Performance.............................................18

C. Controlled for Tax Overhang......................................22

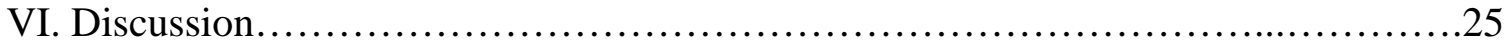

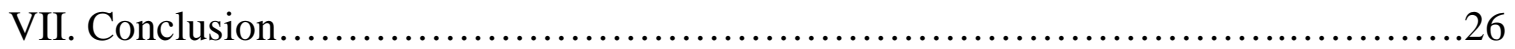

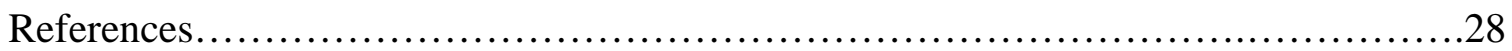

Vita............................................................................ 90 


\section{LIST OF TABLES}

Table 1

Fund Characteristics..........................................................

Table 2

Estimates of the Disposition Spread..........................................33

Table 3.1

Disposition Effect by Deciles

- Value-weighted Disposition Spread

Table 3.2

Disposition Effect by Deciles

- Number-of-shares Weighted Disposition Spread.

Table 4.1

Disposition Effect and Fund Performance

- Value-weighted Disposition Spread.

Table 4.2

Disposition Effect and Fund Performance

- Number-of-shares Weighted Disposition Spread.

Table 5.1

Disposition Effect and Fund Performance Regression Results

- Value-weighted Disposition Spread.

Table 5.2

Disposition Effect and Fund Performance Regression Results

- Number-of-shares Weighted Disposition Spread.

Table 6.1

Characteristics of Portfolios by Performance and Disposition Spread

- Value-weighted Disposition Spread.

Table 6.2

Characteristics of Portfolios by Performance and Disposition Spread

- Number-of-shares Weighted Disposition Spread.

Table 7.1

Disposition Effect and Fund Flows

- Value-weighted Disposition Spread 
Table 7.2

Disposition Effect and Fund Flows

- Number-of-shares Weighted Disposition Spread.....

Table 8.1

Disposition Effect and Fund Performance Regression Results

- Value-weighted Disposition Spread.

Table 8.2

Disposition Effect and Fund Performance Regression Results

- Number-of-shares Weighted Disposition Spread.

Table 9

Tax Overhang and Fund Flows............................................69

Table 10

Tax Overhang, Disposition Effect and Fund Flows...............................74

Table 11

Disposition Effect and Fund Flows Controlling for Performance and Tax

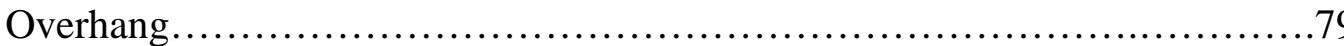

Table 12

Tax Overhang, Disposition Effect and Fund Flows............................86 


\section{LIST OF FIGURES}

Figure 1

Histogram of the Value-weighted Disposition Spread.............................88

Figure 2

Histogram of the Disposition Spread Weighted by Number of Shares................89 


\section{Selling Winners, Holding Losers: Effect on Mutual Fund Performance and Flows}

\section{Introduction}

The tendency of individual investors to make seemingly irrational decisions because of emotions or limited understanding has been widely documented in the literature. Among these errors is the disposition effect: the tendency to sell winners too quickly and to hold on to losers for too long. Shefrin and Statman (1985), Grinblatt and Keloharju (2001), Weber and Camerer (1998), Case and Shiller (1988), Genesove and Mayer (2000), and Shapira and Venezia (2002) are a few articles documenting the disposition effect among retail investors. Odean (1998) also finds that this disposition behavior negatively impacts the return performance of retail investors.

The disposition effect is not limited to individual investors. Several recent articles find that many mutual funds also sell their winners too quickly and hold on to their losers for too long. Frazzini (2006) finds a disposition effect among mutual funds following earnings announcements. He contends that this may be partly responsible for the post-earnings announcement drift. Cici (2006) reports the presence of a weak disposition effect and finds that funds that are disposition-prone tend to underperform other funds. Wermers (2003) argues that certain funds underperform because the managers of those funds appear reluctant to sell their losing stocks. And Scherbina and Jin (2005) document that newly hired fund managers tend to dispose off losing stocks that previous managers were reluctant to sell in a bid to improve performance. In addition, Locke and Mann (2000), Coval and Shumway (2000), and Shapira and Venezia (2001) find evidence of a disposition effect among futures traders, professional market makers at the Chicago Board of Trade, and professional investors in Israel, respectively.

This study examines the impact of the disposition effect on mutual fund performance, but more importantly, how the disposition effect and fund performance affect fund flows. Since fund manager compensation is largely determined by assets 
under management, ${ }^{1}$ the link between the disposition effect and fund flows provides evidence regarding whether or not managers are acting in their best self-interest. One possible explanation for this kind of behavior is that disposition-prone funds attract larger fund flows, which justifies their propensity to sell winners.

There are several reasons why the disposition effect might influence fund flows. First, the early disposal of winners and late disposal of losers could hurt fund performance to the extent that it runs contrary to the momentum effect. Cici (2005) provides evidence to suggest that the disposition effect affects fund performance. The relationship between fund performance and fund flows has been documented earlier (Ippolito, 1992; Gruber, 1996; Chevalier and Ellison, 1997; Sirri and Tufano, 1998). The connection between performance and flows is strong, especially for funds with high performance though investors fail to flee from funds with poor performance. Thus, the disposition effect should negatively impact fund inflows via poor performance.

Second, the disposition effect is a behavioral trait that is likely to persist from one year to the next. If disposition effect hurts performance and there is persistence in the disposition effect, it is reasonable to expect that poor performance will also persist. Therefore, expected future underperformance will hurt current fund inflows.

Third, disposition behavior could also impact flows through its effect on taxes. Disposal of winners reduces the amount of unrealized gains held by the fund. Barclay, et al. (1998) present a model in which unrealized capital gains increase the present value of a new investor's tax liability. Other things equal, a large overhang should reduce subsequent inflows into the fund. Indeed, Bergstresser and Poterba (2002) find that funds with a large overhang experience smaller inflows than funds without such unrealized gains. In this background, the disposition effect should increase fund inflows because disposition-prone funds will realize most of their gains limiting the tax overhang that may discourage future investors.

\footnotetext{
${ }^{1}$ The importance of fund flows has not escaped notice. There are numerous studies that have examined why fund investors decide to put money in a particular fund. These papers have found that larger inflows occur for funds that are older (Chevalier and Ellison, 1997), have low volatility of past performance (Sirri and Tufano, 1998; and Huang, et al., 2006), are affiliated with large or "star"-producing fund complex (Sirri and Tufano, 1998; Khorana and Servaes, 2004; Massa, 2003; Nanda, Wang and Zheng, 2004a), and incur higher marketing expenditure and participation costs (Sirri and Tufano, 1998; Jain and Wu, 2000; Gallaher, Kaniel and Starks, 2004; and Huang, et al., 2006).
} 
Alternatively, realization of capital gains increases current period tax liability for investors because tax laws require mutual funds to distribute net realized capital gains in the year they are realized. Bergstresser and Poterba (2002) find that after-tax returns have more explanatory power than pretax returns in explaining inflows. Thus, the disposition effect may hurt fund flows via its impact on tax efficiency for current shareholders. The overall impact of the disposition effect on fund flows remains an empirical issue that we investigate.

We begin by reexamining the relationship between disposition effect and fund performance by extending the work of Frazzini (2006) and Cici (2006). Using a sample of 1,960 actively managed U.S. equity funds (excluding index funds and special funds) covering the 1980-2004 period, we find that, on average, fund managers do not sell their winners too quickly nor do they hold on to their losers. They are much more likely to realize their losses in the last calendar quarter than in the first calendar quarter to postpone the tax liability of their constituents. However, there is much heterogeneity among the fund managers. Along with managers who are not disposition prone, we find that about $22 \%$ of the funds are likely to sell their winners faster than their losers if such behavior is measured by value-weighted disposition spread, or $32 \%$ of the funds are disposition prone if the measure is weighted by number of shares. We find that the propensity to dispose off winners affects fund performance. If divide the funds into deciles by their disposition spread (percent of realizable gains actually realized minus percent of realizable losses actually realized), we notice that funds with the most positive disposition spread (disposition prone) significantly underperform funds that have the most negative disposition spread (not disposition prone) by 4-6\% per year

We further examine the impact of the disposition effect on fund flows without controlling for performance as well as after controlling for performance. Funds are grouped by the disposition effect alone and flows among different fund groups are compared. The flows are 2-3\% more each quarter for funds that are not disposition prone than for other funds. This difference in flows may be due to the superior performance of non-disposition prone funds. 
If there is an expectation for future performance to be affected by current disposition behavior due to persistence, the disposition effect controlled for current performance would still affect fund flows. To examine this explanation, we control for performance by first grouping funds into deciles based on performance. Within each performance decile, we compare the flows to non-disposition prone funds with flows to disposition-prone funds. Even after controlling for performance, we find that funds with a high disposition effect experience $0.7-2 \%$ less flows than those without such behavior.

The last piece of the disposition effect and fund flow puzzle concerns the tax overhang. Funds that are disposition prone are likely to have a lower tax overhang because those funds sell their winners quickly. Past research has found that funds with low tax overhang experience higher level of flows. We examine whether the disposition effect still affects fund flows after tax overhang is controlled. We calculate the tax overhang at the beginning of each quarter and examine the variation in fund flows. Consistent with prior results in Barclay, et al. (1998) and Bergstresser and Poterba (2002), we find that funds with low tax overhang have higher flows. Moreover, after controlling for tax overhang, we find that fund flows to disposition-prone funds are smaller than flows to non-disposition oriented funds. This result is consistent with the notion that investors are concerned more with after-tax returns than before-tax returns. Overall, we find that the disposition effect is negatively related to fund performance and negatively related to fund flows. These results suggest that both performance and tax efficiency are important to mutual fund investors.

We contribute to the literature in several ways. We reconfirm the presence of disposition effect among mutual fund managers using a more realistic method of computing the cost basis (HIFO - highest-price in, first out). We also reconfirm that the disposition effect has a negative impact on performance. Second, we find that most fund managers pay attention to the tax consequences of their trades and are more likely to sell losers in the last calendar quarter compared to the first calendar quarter. Third and most importantly, we note that, besides the effect on performance, disposition behavior has a negative impact on mutual funds from other angles. Selling winners more readily than selling losers hurts the tax efficiency of these funds. The disposition effect, controlled for underperformance, also hurts investor flows into these funds. Whereas the behavior of 
mutual fund managers exhibiting the disposition effect seems to be irrational, individual investors make smart decisions about which mutual funds to invest in. The lack of flows into disposition-prone funds suggests that this irrational behavior is not sustainable and that, over a period of time, these types of funds will shrink and die.

The rest of the paper is organized as follows. Section II describes the data and sample. Section III presents the procedure for estimating the disposition effect and estimates of the disposition effect, while Section IV examines the relationship between the disposition effect and performance. Section V presents and discusses the impact of disposition effect on fund flows without controlling for performance and after controlling for performance. Section VI discusses possible contemplations of the disposition effect among mutual fund managers. Section VII concludes.

\section{Data and Sample}

Our data come from three main sources: quarterly fund holdings data from Thomson Financial, monthly mutual fund database from CRSP, and daily and monthly stock return files from CRSP. The Thomson and CRSP mutual fund databases are matched using ticker symbols and names. There are 4,234 fund matches. Since we are interested in actively managed U.S. equity funds only, we must exclude other types of funds such as bond funds, sector funds, international funds, balanced funds and index funds. ${ }^{2}$ Thomson and CRSP both provide classifications by investment objectives. We use Thomson classification for initial identification of equity funds because Thomson uses a continuous and consistent basis for classification over the entire period. Huang, et al. (2006), for example, use only Thomson classifications. Using Thomson objectives 2 (Aggressive Growth), 3 (Growth), and 4 (Income), we identify 3,434 equity funds. The funds include some funds years where no investment objective code was assigned by Thomson. The non-qualifying funds and all equity funds initially identified using

\footnotetext{
${ }^{2}$ Index funds aim at replicating the performance of indexes by holding all of the securities in the indexes and weighting all of the securities in the same proportions as the indexes. Therefore, index funds are considered passively managed funds.
} 
Thomson objectives would be further screened in the next step using the CRSP investment objectives.

CRSP's classification system is more complete but disjointed. It has Wiesenberger objectives for the 1980-1991 period but Strategic Insight objectives from 1992-2004. There are 10 Weisenberger objectives that are of interest to us: they are G, G-I, G-I-S, G-S, GCI, I-G, I-S-G, MCG, SCG and IEG, where I refers to Income, G to Growth, S to Small, C to Capital Appreciation, and M to Midcap. The six Strategic Investment objectives of interest to us are AGG, GRI, GRO, ING, SCG and GMC. The Wiesenberger objectives do not map into the SI objectives; therefore it is not possible to construct a single series for all of the funds. Instead, we use a combination Wiesenberger for 1980-91 and SI for 1992-2004. Similar techniques have been used by Pastor and Stambaugh (2002), Cici (2006), and Kacperczyk, et al. (2005).

Using a combination of these investment objectives, we are able to exclude additional non-equity funds reducing our sample size to 2,188 funds. Many funds contain multiple classes. Since the portfolio of stocks held by a fund is the same for all classes, we use only one share class for each fund by selecting the one with the largest year-end total net assets. If during a fund's life time, the largest share class changes, we choose the one with the longest date range.

Fund holdings may deviate from their investment objectives. To ensure that our sample consists of only actively managed equity funds, we include those funds where investment in equities is at least $80 \%$. Using asset composition data reported from CRSP, we are able to exclude 63 funds whose equity asset values are less than $80 \%$ of their total net assets.

In addition, 135 index funds are dropped from the sample. Index funds are identified by regressing monthly fund returns on index returns, separately for S\&P500 and Russell 2000. If the R-square is greater than $95 \%$ and the beta lies between 0.90 and 1.10, then the fund is tagged as an index fund. Finally, we require holdings data for at least two consecutive quarters. 30 funds fail to meet this data requirement. Our final sample consists of 1,960 funds. 
The summary statistics of the sample are reported in Table 1 . The number of funds increases substantially from 290 in 1980 to 1309 in 2004. Both the mean and median total net assets increase over the 25-year period. It is interesting to note that the median fund size in 2004 was \$238 million, equivalent to \$104 million in 1980 adjusted for inflation. It doubles the median fund size of $\$ 52$ million in 1980. The turnover was about 50-75\% in 1980 implying a holding period between 1.3 and 2 years. In recent years, the turnover has increased to $75 \%$ to $90 \%$. Consequently, the holding period has decreased to 1.1 years to 1.3 years. This turnover is comparable to that documented in prior research. For example, Kacperczyk et al (2005) finds an average turnover of 88\% over the 1984-1999 period. And Cici (2006) finds an average turnover of 97\% during the 1980-2004 period. As we observe later in the paper, the short holding period is not tax efficient for investors.

The trends in expense ratio and total load are also interesting. The total load has fallen dramatically from an average of about 4\% per year in 1980 to about 2\% in 2004, with the median falling from $3.25 \%$ in 1980 to $0 \%$ in 2004 . On the other hand, however, the expense ratio has risen from 1\% per year in 1980 to about $1.25 \%-1.40 \%$ in 2004 . It seems that the decline in loads has been compensated by an increase in expense ratios. The capital gains tax rate and the holding period have varied significantly over the last 25 years. The variation allows us to examine the effect of changes in the tax rates on the disposition effect.

\section{Estimates of the Disposition Effect}

The disposition effect is a measure of how quickly a fund manager realizes available capital gains and available capital losses. We follow Odean (1998) in estimation of the disposition spread calculated as the difference between the proportion of capital gains realized (PGR) and the proportion of capital losses realized (PLR). A fund's PGR and PLR are measured as

$$
P G R_{i, t}=\frac{R C G_{i, t}}{R C G_{i, t}+U C G_{i, t}}
$$


$P L R_{i, t}=\frac{R C L_{i, t}}{R C L_{i, t}+U C L_{i, t}}$

where $R C G_{i, t}$ and $R C L_{i, t}$ are realized capital gains and losses and $U C G_{i, t}$ and $U C L_{i, t}$ are unrealized capital gains and losses for fund $i$ in quarter $t$.

$R C G_{i, t}, R C L_{i, t}, U C G_{i, t}$ and $U C L_{i, t}$ are reported by value-weighting and by weighting by the number of shares.

The end-of-the-quarter holdings data are obtained from Thomson Financial. Holdings are adjusted for stock splits by using the adjustment factor on CRSP. Due to limitations of the data and consistent with Cici (2006), Huang, et al. (2006), Frazzini (2006), we assume that all changes in holdings occur at the end of a quarter. By comparing the holdings at the end of one quarter with holdings at the end of the previous quarter, we are able to determine the sales that occurred during the quarter. The cost basis is historical since we track the funds over several years. Gains and losses for each stock are aggregated by fund to calculate PGR, PLR and the disposition spread.

Corporate events can significantly affect the return series and seemingly affect holdings of mutual funds. In particular, events such as spinoffs, mergers, privatizations, and liquidations can cause involuntary changes in ownership. Realized capital gains or losses due to such involuntary changes shouldn't be included in the calculations of the disposition spread. We use the delisting information from CRSP to determine whether and when delisting events occur. ${ }^{3}$ We adjust decreases in holdings due to delisting such that capital gains and losses incurred from delisting events are not included in calculations of the disposition spread.

Spinoff is a special corporate event, which may cause the price of the mother stock to drop substantially while giving ownership of the newly spun-off company to the current owners of the mother stock. As a result, selling the mother stock may incur capital losses involuntarily. In the quarter when a spinoff took place, we exclude the decrease in the mother stock from the calculation of the disposition spread. However, if there is an increase in the holdings of the mother stock, we consider it as a voluntary

\footnotetext{
${ }^{3}$ We assume that the delisting dates on CRSP are the event dates.
} 
purchase and include the purchase price in the calculation of cost basis. Event dates for spinoffs are obtained from the SDC Platinum database.

When a fund changes its manager, new manager is likely to make dramatic changes to the fund's holdings. Purchases and sales that a new manager makes at the beginning of his employment are driven by many reasons, and therefore do not represent the new manager's typical trading behavior. CRSP has information about fund managers' names and when each fund manager started employment. We use these data to determine the quarters where fund managers are replaced, and drop those quarters from the sample testing period. ${ }^{4}$ Any purchases in those quarters are still included in the calculations of the cost bases.

Computing the cost basis is an important determinant of capital gains and losses. First in first out (FIFO), Last in first out (LIFO), Average-price in first out (AIFO), and Highest-price in first out (HIFO) are the bases that can be used. From a current investor's point of view, HIFO provides the best after-tax return. Odean (1998), Grinblatt and Keloharju (2001) and Cici (2006) use AIFO to calculate cost basis. And Frazzini (2006) uses FIFO to construct the cost-basis.

Results based on the assumption that mutual fund managers sell stocks with the highest basis first (HIFO) are reported in Table $2 .^{5}$ Panel A has the results based on value-weighting while Panel $B$ reports the disposition effect based on the number of shares. Columns titled "PGR" and "PLR" contain information about realized gains and realized losses. It can be seen that the proportion of gains realized is always less than the proportion of losses realized. Not surprisingly, the disposition effect (last column) is consistently negative in both panels, across quarters, and for both means and medians. This implies that mutual funds realize more of their losses than gains each quarter and that the average mutual fund is not disposition prone. Overall, the disposition spread has a mean of $-18.0 \%$ with a median of $-17.5 \%$ in terms of dollar value, and a mean of $-5.6 \%$

\footnotetext{
${ }^{4}$ Fund managers information is available from CRSP since 1993. So for early years of 1980-1992, we are not able to identify funds where there were manager changes.

${ }^{5}$ Results with other cost bases, not reported, are qualitatively similar.
} 
with a median of $-5.1 \%$ in terms of number of shares. ${ }^{6}$ The average mutual fund realizes $43.8 \%$ of available losses compared with $25.8 \%$ of available gains each quarter. This finding is in contrast to what Frazzini (2006), Wermers (2003) and Scherbina and Jin (2005) imply about fund managers' reluctance to realize capital losses but the result is consistent with the evidence in Cici (2006).

Two other observations are important. We find that there is some evidence to suggest that mutual funds manage their tax liability towards the end of the year. The fiscal year-end for mutual funds was December $31^{\text {st }}$ until 1986 and has been October $31^{\text {st }}$ since 1988. In both cases, the fiscal year-end lies in the last quarter. However, the start of the new year is also in the last calendar quarter of the year beginning with 1988. Nonetheless, the results are indicative. It can be seen that the disposition spread is much more negative in the last quarter than in the first quarter suggesting tax management by mutual funds. The difference is statistically significant with a t-stat of 12.31 for Panel A and a t-stat of 18.08 for Panel B. The difference comes from the difference in the proportion of capital losses fund managers tend to realize (PLR). On average, fund managers realize $3.5 \%$ more value-weighted PLR in the $4^{\text {th }}$ quarter than in the $1^{\text {st }}$ quarter, and $2.8 \%$ in terms of the PLR weighted by number of shares.

Finally, the range of the dispersion spread reported in Table 2 reveals that there is a significant cross-sectional variation in how mutual funds behave. The $25^{\text {th }}$ and $75^{\text {th }}$ percentiles of the value-weighted disposition spread are $-34.9 \%$ and $0.6 \%$. On average, there are 22\% funds with positive disposition spreads in each quarter if disposition spreads are value-weighted, or 32\% such funds if disposition spreads are weighted by number of shares. Figure 1 and Figure 2 show the distributions of the disposition spreads in terms of both weighting schemes. We can observe that the distributions center a little bit to the left of zero, which means that funds are not disposition prone on average. However, there is a large portion of funds exhibiting various degrees of the disposition effect. The values of both disposition spreads range from extremely negative numbers to very large positive numbers. The range is wider for the value-weighted disposition spread

\footnotetext{
${ }^{6}$ Odean (1998) documents an average of 5\% disposition spread for retail investors. Frazzini (2006) reports $3 \%$ disposition spread for mutual funds. Cici (2006) reports the disposition effect with a mean of $-3.5 \%$ for his sample funds.
} 
than for the disposition spread weighted by number of shares. The variation in the disposition spread allows us to examine how the disposition effect affects performance and fund flows in subsequent sections.

\section{Disposition Effect and Fund Performance}

As we suggested above, early disposition of winner stocks and continued holding of loser stocks could potentially hurt returns. We examine the relationship between the disposition effect and performance in this section. While Frazzini (2006) and Scherbina and Jin (2005) examine the disposition effect among institutions, they do not aggregate and evaluate the impact of this behavior on fund performance. This is an important extension to determine whether the disposition effect is a significant factor for fund returns. In this respect, Cici (2006) comes closest to our analysis. However, we report results by quarter in addition to annual estimates. We also weight the disposition estimates using both value and the number of shares. And we use a more realistic cost basis (HIFO) instead of the average price employed by Cici.

The characteristics of disposition spread decile portfolios are reported in Tables 3.1 and 3.2. The disposition spreads in Table 3.1 are weighted by dollar value, whereas in Table 3.2, they are weighted by number of shares. The decile portfolios are constructed by ranking funds based on their disposition spread within each investment category over the past one quarter or the past one year. Thus, we explicitly control for the investment objective as defined by Thomson and as defined by CRSP. The results in Panels A and B are for formation periods of one quarter and one year rolling forward one quarter at a time. The mean disposition spread varies from $-64.1 \%$ for the lowest decile to $+23.9 \%$ for the highest decile in Table 3.1, and from $-43.5 \%$ to $29.5 \%$ in Table 3.2. In Table 3.1, the top two or three deciles, depending on the portfolio formation period, have a positive mean disposition spread. In Table 3.2, the top four deciles have a positive mean disposition spread. These are funds that are more likely to exhibit disposition behavior. Based on the measure weighted by the number of shares, more funds are defined as disposition prone. 
From Tables 3.1 and 3.2, no definitive relationship can be discerned between the disposition spread and total net assets or expense ratio. The total net assets rise as the disposition spread rise but then begin to fall beyond decile 7. Similarly, the expense ratio falls as the disposition spread increases but again it rises beyond decile 7. Surprisingly, the turnover decreases with increase in the disposition spread, although turnover in decile 10 is high in Table 3.1. Funds with low disposition spreads have higher turnover than funds that are more disposition-prone. This may indicate that fund managers try to offset realized gains by realizing losses and indicates that high turnover is not necessarily associated with tax inefficiency.

The negative relationship between the disposition spread and funds' past returns is striking. Funds in the low disposition spread deciles outperformed funds in the high disposition spread deciles over the prior 12-month period. The difference between deciles 1 and 10 is a statistically and economically significant 4.7\% per year in Table 3.1 and 3.6\% per year in Table 3.2. The results are similar when the formation period is one year instead of one quarter. This pattern is consistent with the evidence reported in other studies. Frazzini (2006) sorts funds into quintiles by their previous year returns and compares the disposition spreads between quintiles. He finds that loser funds show signs of a disposition effect while winner funds show a much weaker disposition effect. Cici (2006) also finds that funds with strong disposition effects have lower past returns. Funds' past return volatilities seem to be almost monotonically negatively related to their disposition spreads, which suggests that disposition-prone portfolios are subject to a lower level of total risk.

Following the relationship between disposition spread and past performance, we examine the relationship between disposition spread and contemporaneous performance in Tables 4 and 5. Disposition spread decile portfolios are constructed in the same manner as for Tables 3.1 and 3.2. Correspondingly, the disposition spreads in Tables 4.1 and 5.1 are weighted by dollar value, and by the number of shares in Tables 4.2 and 5.2. All returns are reported for the quarter or year contemporaneous with the formation period. In addition to the monthly raw returns, monthly alphas from 3-factor and 4-factor regression models are also reported. 
$r_{i, t}=\alpha_{i, t}+\beta_{i, M K T} M K T_{t}+\beta_{i, S M B} S M B_{t}+\beta_{i, H M L} H M L_{t}+\varepsilon_{i, t}$

$r_{i, t}=\alpha_{i, t}+\beta_{i, M K T} M K T_{t}+\beta_{i, S M B} S M B_{t}+\beta_{i, H M L} H M L_{t}+\beta_{i, U M D} U M D_{t}+\varepsilon_{i, t}$

Where $r_{i, t}$ is the return on a portfolio in excess of the one-month T-bill return; MKT is the excess return on the market portfolio, and $S M B, H M L$, and $U M D$ are returns on value-weighted, zero-investment, factor-mimicking portfolios for size, book-to-market equity, and one-year momentum in stock returns. There is a direct correlation between the disposition deciles and the raw return as can be observed from an almost monotonic decrease in raw return with an increase in the disposition spread. In Table 4.1 Panel A, the raw return falls from $1.35 \%$ per month to $0.83 \%$ per month when we move from decile 1 to decile 10 . The difference of $0.52 \%$ per month is statistically and economically significant. Similar results can be found when the portfolio formation period is one year as shown in Panel B, and when the disposition spreads are weighted by the number of shares as shown in Table 4.2. We consider the fund flows reported in the last two columns of Tables 4.1 and 4.2 in the next section.

The relationship between the disposition spread and risk adjusted returns is equally impressive. The almost monotonic decrease in risk-adjusted return with disposition spread persists for both 3-factor and 4-factor alphas. The difference in returns between deciles 1 and 10 is $0.36 \%$ per month and $0.24 \%$ per month for 3 -factor and 4 factor models in Table 4.1 Panel A, and $0.26 \%$ and $0.20 \%$ respectively in Table 4.2 Panel A, all of which are statistically and economically significant. Similar results can be observed from Panel Bs in Tables4.1 and 4.2 where the formation period is one year

There are interesting findings when we compare raw returns, 3-factor alphas and 4 factor alphas within each disposition decile and across disposition deciles. Not surprisingly, within each disposition decile, raw return is higher than either risk adjusted return. For example, from Table 4.1 Panel A, the decile 1 portfolio has the average raw return of $1.27 \%$ per month, 3 -factor alpha of $0.16 \%$ per month and 4 -factor alpha of 0.09\% per month. Between these two risk-adjusted returns, 3-factor alpha is higher than 4-factor alpha since 4-factor alpha is adjusted for one more risk factor - the momentum factor. More interestingly, the return difference between decile 1 and decile 10 is largest 
in terms of raw return , smaller in terms of 3-factor alpha, and smallest in terms of 4factor alpha. From Table 4.1 Panel A, we can observe that decile 1 outperform decile 10 by $0.46 \%$ per month in terms of raw return, $0.26 \%$ in terms of 3 -factor alpha, and only $0.20 \%$ in terms of 4 -factor alpha. The same pattern can be observed from Panel B where the portfolio formation period is one year, and from Table 4.2 where the disposition spreads are weighted by the number of shares. The evidence that the difference in returns becomes smaller after controlling for the momentum effect is consistent with the conjecture that the disposition effect hurts fund performance because this behavior is contrary to the momentum effect. However, the return difference in terms of 4-factor alpha is still statistically and economically significant. This significance suggests that momentum effect is not the only reason for the underperformance of disposition prone funds.

Besides the panel results in Tables 4.1 and 4.2, we report regression results in Tables 5.1 and 5.2 by controlling for factors known to affect performance in accordance with Cici (2006). The regression model is given below:

$$
\begin{aligned}
& \text { Performance }_{i, t}=a_{i, t}+b_{1} \times \text { Disp }_{i, t}+b_{2} \times \text { LnTNA }_{i, t}+b_{3} \times \operatorname{Exp}_{i, t}+b_{4} \times \operatorname{Load}_{i, t} \\
& +b_{5} \times \text { Turnover }_{i, t}+b_{6} \operatorname{Ret}_{i, t}+\varepsilon_{i, t}
\end{aligned}
$$

where performance is the risk-adjusted return of fund $i$ in quarter $t$ from 3-factor or 4factor model, Disp $_{i, t}$ is the disposition spread of fund $i$ in quarter $t, \operatorname{LnTNA}_{i, t}$ is natural log of total net assets for fund $i$ in quarter $t, \operatorname{Exp}_{i, t}$ is fund $i$ 's expense ratio, Load $_{i, t}$ is fund $i$ 's maximum load, Turnover ${ }_{i, t}$ is fund $i$ 's turnover rate, and Ret $_{i, t}$ is the fund $i$ 's return of last quarter.

The main result from Tables 5.1 and 5.2 is that fund performance is negatively related to the dollar value-weighted disposition spread. In Table 5.1, the coefficient on the disposition spread is a statistically significant -0.0142 for the 3-factor model and a statistically significant -0.0075 for the 4 -factor model. In economic terms, it means that each $1 \%$ increase in the disposition spread decreases the return by $0.014 \%$ per month. The difference between the mean disposition spread for decile 1 and decile 10 is $88 \%$ from Panel A of Table 3.1. Thus the difference in returns is $1.23 \%$ per quarter or $0.41 \%$ 
per month, in the same magnitude with the $0.52 \%$ per month in Table 4.1. In Table 5.2, the coefficients on the disposition spread are more negative than corresponding ones in Table 5.1. However, the difference between the mean disposition spread from decile 1 and decile 10 is $72 \%$ in Table 3.2 where the disposition spreads are weighted by the number of shares. As a result, the difference in returns is $1.24 \%$ per quarter. The economic significance of the disposition effect is very similar in terms of both measures of the disposition effect. More interestingly, the coefficients on the disposition spread are more negative for the 3-factor models than for the 4-factor models, which suggests that the momentum effect partially explains the underperformance of the disposition prone funds. This result is consistent with the findings from Tables 4.1 and 4.2.

The coefficients on the control variables suggest that active management doesn't add value to fund performance: higher expense ratios and loads hurt performance but performance is unrelated to fund size. There is not much consistent guidance from previous work. According to Droms and Walker (1994) and Grinblatt and Titman (1994), there is no statistical relationship between expense ratio and mutual fund performance. Similarly, Ippolito (1989) finds that funds are not negatively impacted by higher expenses. Loads hurt performance according to Elton, et al. (1993), Carhart (1997) and Droms and Walker (1994) but Grinblatt and Titman (1994) find that a significant positive relationship existed between sales load and performance of 279 equity mutual funds for the period 1975-1984. As for fund size, Chen, et al. (2004) document that fund returns decline with lagged fund size. Our results add to the existing literature on the subject.

We do not observe a consistent relationship between turnover and performance. Wermers (2000) finds that funds in the top turnover decile exhibit the greatest stockpicking ability but incur large estimated trading costs and fund expenses. More importantly, we find some persistence in fund performance. As for performance persistence, Hendrick, et al., (1993) and Brown and Goetzmann (1995) find the persistence among poor performing funds. Grinblatt and Titman (1992) and Ibbotson and Goetzmann (1994) find evidence of repeated winners. Bollen \& Busse (2003) find shortterm persistence in mutual fund performance, whereas Wermers (2003) finds long-term persistence in mutual fund returns. 
Overall, our results confirm the evidence in Cici (2006) that the disposition effect hurts performance. One obvious reason for the underperformance comes from momentum in stocks discovered by Jegadeesh and Titman (1993, 2001). However, we find evidence of underperformance even after controlling for momentum in a 4-factor return generating model.

\section{Disposition Effect and Fund Flows}

The ultimate impact of the disposition effect is on fund flows. Fund flows are important to fund families and fund managers because their profits and compensation are closely tied to the assets under management. If there is no impact of the disposition effect on fund flows, the disposition-prone behavior is unlikely to change. On the other hand, if the disposition effect hurts fund flows, then we would expect such funds to close and the managers and fund families will exit the institutional investment industry. As explained in the introduction disposition effect can affect fund flows through performance and taxes. We consider each factor in turn.

In the previous section, we showed that disposition behavior hurts performance. In addition, prior work has found that performance is related to future flows, particularly for superior performance. Thus, it is reasonable to expect that disposition effect will negatively impact current flows. The disposition effect can affect flows in another way via performance. Since disposition behavior is a personality trait that is unlikely to change over time, funds that sell winners and hold losers in one period are likely to repeat that behavior in following periods. Therefore, underperformance of disposition-prone funds will continue in the future hurting future flows.

The disposition effect could affect flows via taxes. If a fund manager realizes gains and holds on to losses, it will increase taxable capital gains distributions to the shareholders. As a result, the disposition effect will deter tax sensitive investors from pouring new money into the fund. The negative influence of the disposition effect on fund flows is likely to be stronger when the capital gains tax rate is high. Finally, disposal of winners reduces the amount of unrealized gains held by the fund or the capital 
gains overhang. Since overhang increases the present value of a new investor's tax liability, there should be a positive relationship between disposition spread and flows.

In this section, we investigate the impact of the disposition effect on fund flows in two ways: without controlling for performance and after controlling for performance.

\section{A. Without Controlling for Performance}

To test the direct relationship between disposition effect and flows, we calculate each fund's flow in the quarter following the formation period of disposition deciles. Since we do not know exactly when cash flows occur within each quarter, we calculate fund flows based on two different assumptions. If new money is assumed to be invested at the end of each quarter, fund flows are calculated as

$$
F L_{i, t}=\frac{T N A_{i, t}-T N A_{i, t-1}\left(1+r_{i, t}\right)}{T N A_{i, t-1}}
$$

where $T N A_{i, t}$ is the total net assets of fund $i$ at the end of quarter $t$, and $r_{i, t}$ is the total return of fund $i$ in quarter $t$. Funds total net assets and return data are from CRSP mutual fund database. If we assume that new money is invested at the beginning of each quarter, fund flows are calculated as

$$
F L_{i, t}=\frac{T N A_{i, t} /\left(1+r_{i, t}\right)-T N A_{i, t-1}}{T N A_{i, t-1}}
$$

We conduct tests involving fund flows under both assumptions. Since the empirical results are qualitatively the same, we only report the test results assuming that new investment occurs at the end of each quarter.

Fund flows in the quarter immediately after the ranking periods are reported in the last two columns of Tables 4.1 and 4.2. The results reveal that fund flows are negatively related to the disposition spread. Funds in the decile with the lowest disposition spread enjoy the highest level of inflows while funds in the highest disposition spread decile have the lowest level of inflows. The relationship between disposition spread and

\footnotetext{
${ }^{7}$ Chevalier an Ellison (1997), Sirri and Tufano (1998), and Huang, et al. (2006) use this measure.
} 
inflows is almost monotonic in both Panels A and B. However, fund performance is also strongly related to the disposition spread. Thus, it is not clear from Tables 4.1 and 4.2 whether the relationship between the disposition effect and flows is due only to performance. In the next subsection, we explore this relationship after controlling for performance.

\section{B. Controlled for Performance}

To control for performance, we first sort funds into deciles based on their performance within each investment category. Fund performance is measured by raw return since it is more salient to investors than the risk-adjusted return. Within each performance decile, we sort funds into quintiles based on their disposition spreads over the same period. ${ }^{8}$ Funds in the top quintile have the highest disposition spread (Disp), and funds in the bottom quintile have the lowest disposition spread (Nondisp).

The portfolio characteristics are summarized in Tables 6.1 and 6.2. ${ }^{9}$ The last columns in both tables show the past 12-month returns. By design, the performance increases from the bottom decile (decile 1) to the top decile (decile 10). However, within each decile except decile 10 in Table 6.1, performance of the non-disposition oriented funds is better than the performance of the disposition oriented funds. This suggests that the disposition spread is related to past performance even after controlling for current performance. Moreover and curiously, funds with high and low disposition effects are almost uniformly spread over all ten performance deciles. This implies that the disposition effect can only explain part of the performance. Non-disposition prone funds have higher turnover than disposition-prone funds, which is similar to the results in Tables 3.1 and 3.2. There are no obvious patterns on expense ratio and total net assts between non-disposition prone funds and disposition prone funds or across performance decile portfolios.

\footnotetext{
${ }^{8}$ To save space, we report results using a formation period of 1 quarter only. Results using 1 year for computing the disposition spread are similar, and are available from the authors.

${ }^{9}$ Similar to earlier tables, Table 6.1 reports results based on the valued-weighted disposition spreads, while results in Table 6.2 are based on the disposition spreads weighted by number of shares.
} 
We extend the analysis in Tables 6.1 and 6.2 by computing the flows for the quarter immediately following the formation period. The fund flows are defined as given by equation (6) and (7) above. ${ }^{10}$ The analysis is conducted over the entire sample period, and repeated over three sub-sample periods that reflect three different regimes for the capital gains tax rate. 1980-1987 and 1998-2004 are periods when the capital gains tax rate is low, and 1987-1997 is a period when the capital gains tax rate is high. The results for the entire sample period and the three subsamples are reported in Panel Bs of Table 7.1 and 7.2. To examine the relationship at a more aggregate level, we group funds into three broader groups by their performance. Specifically, the bottom 2 return deciles are aggregated into Low performance group (Low), the middle 6 deciles into Medium performance group (Med) and the top 2 deciles into High performance group (High). Within each return group, the funds are ranked into quintiles by their disposition spread. The quintile with the highest disposition spread (Disp) and the quintile with the lowest disposition spread (Nondisp) are chosen for analysis. These results are in Panel As of Tables 7.1 and 7.2.

The results in Tables 7.1 and 7.2 confirm the conclusions of past research that better performing funds have larger inflows. The mean columns for 1980-2004 show that the flows increase almost monotonically with performance. The flows are negative for funds in the bottom return decile (\#1) and the Low performance group but strongly positive for the top return decile (\#10) and the High performance group. The differences in inflows to non-disposition prone funds and disposition prone funds confirm our hypothesis that non-disposition prone funds enjoy a higher level of flows than disposition prone funds. Within each return group, we can see that non-disposition prone portfolios always have higher level of flows than disposition prone portfolios. The flow differences are larger in the High performance group. For the 1980-2004 period, the flow differences for high performance group is $2.33 \%$ and $1.13 \%$ for the Low performance group in Table 7.1, and $1.46 \%$ and $0.84 \%$ respectively in Table 7.2 . All of these differences are statistically significant. Similar results can be found at the decile levels. Within each

\footnotetext{
${ }^{10}$ All tests regarding flows are conducted using both measures and results are similar. However, the disposition spreads are calculated under the assumption that trades happen at the end of each quarter. For the consistency reason, the results reported in the paper are from the tests where the flows are measured under the same assumption.
} 
performance decile, non-disposition prone portfolios almost always have higher level of flows than disposition prone portfolios. The flow differences are generally larger in top return deciles than in bottom return deciles.

The subsamples provide further insight into the disposition behavior as related to the capital gains tax rate. The effect from capital gains tax rate is prominent in high performance group, which attracts disproportionably large amounts of new money.

The flow differences between non-disposition prone funds and disposition prone funds in the High performance group are larger in the period of 1987-1997 when the capital gains tax rate is as high as $28 \%$. The flow differences are smaller in the other two sub-periods.

The evidence from Tables 7.1 and 7.2 confirm that investors chase superior performance. Second, it shows that investors recognize the tax consequences of the disposition effect, and choose to invest more in non-disposition prone funds within the same performance decile. Finally, from the subperiod analysis, we find that investors are more sensitive to tax consequence of their investments when the capital gains tax rate is high.

The panel results in Tables 7.1 and 7.2 do not explicitly control for many factors that may affect flows. Therefore, we use regression analyses to further test the relationship between the disposition effect and fund flows. We run Fama-MacBeth regressions to test the relationship between the disposition effect and fund flows, controlling for other factors that could affect fund flows as documented the literature. The regression model is specified in equation (8). Flow $_{i, t}=\alpha+b_{1} \times \operatorname{Low}_{i, t-1}+b_{2} \times \operatorname{Med}_{i, t-1}+b_{3} \times$ High $_{i, t-1}+b_{4} \times$ Disp $_{i, t-1}+$ Controls $+\varepsilon_{i, t}(8)$

where $F$ low $_{i, t}$ is fund flow as defined in equation (6). The low, medium, and high groups correspond to the bottom two deciles, middle two deciles, and top two deciles of performance as measured by raw return over the previous quarter. All funds are assigned a continuous rank ranging from zero (worst) to one (best), with the rankings corresponding to their return performance percentiles. The fractional rank for funds in the low group is defined as Min (Rank, 0.2). Funds in the medium group get ranks defined as Min (0.6, Rank-Low). Funds in the high group receive ranks defined as Rank-Med-Low. The control variables include volatility of monthly returns during the disposition spread 
measurement period, fund age, natural log of fund size measured by the previous yearend total net asset value, aggregate flow into the fund objective category, expense ratio, previous quarter fund flow, and total fee calculated as annual expense ratio plus oneseventh of the front-end load. ${ }^{11}$ The regression model given by equation (9) examines the impact of disposition effects by using interactive terms with performance.

$$
\begin{aligned}
& \text { Flow }_{i, t}=\alpha_{i, t}+b_{1} \times \operatorname{Low}_{i, t-1}+\beta_{1} \times \text { Low }_{i, t-1} \times \text { Disp }_{i, t-1}+b_{2} \times \text { Med }_{i, t-1} \\
& +\beta_{2} \times \operatorname{Med}_{i, t-1} \times \operatorname{Disp}_{i, t-1}+b_{3} \times \text { High }_{i, t-1}+\beta_{3} \times \text { High }_{i, t-1} \times \text { Disp }_{i, t-1}+\text { Controls }+\varepsilon_{i, t}
\end{aligned}
$$

The dependent variable and control variables are the same as defined for equation (8).

Following Sirri \& Tufano (1998) and Huang, et al. (2006), we run a piecewise linear regression for estimating equations (8) and (9). In the first regression specification, quarterly flows are regressed on the previous quarter's disposition spread controlling for past performance and other characteristics. Results are presented in Tables 8.1 and 8.2. ${ }^{12}$ Consistent with our hypothesis, the coefficient for the disposition effect variable is significantly negative for the entire sample period and as well as for all three sub-periods. The disposition effect is negatively related to fund flows, and the relationship is most negative in the 1987-97 subperiod corresponding with the highest capital gains tax rate period. These results support our hypothesis that fund flows are affected by the disposition effect and by taxes.

The coefficients for performance measures are all positive, and highest for high performance category. This is consistent with what other studies on fund flows have documented: fund flows chase past performance but in an asymmetric way that funds with high performance attract disproportionately large amount of money. The coefficients for control variables such as volatility, age and flows to the investment category are also consistent with the evidence in earlier work. There is a significant negative relationship between fund flow and fund return volatility as reported by Huang, et al. (2006), which suggests that investors are more averse to investing in funds with

\footnotetext{
${ }^{11}$ We also run regressions by separating the $12 \mathrm{~b}-1$ fee from the expense ratio and include both as control variables. $12 \mathrm{~b}-1$ fee data is available since 1992; therefore this regression can only be done for the period of 1992-2004. The coefficient for 12b-1 fee is significantly positive. This variable doesn't change the significance of other variables. Results are not reported, but available from the authors.

12 The disposition spreads in Table 8.1 are weighted by dollar value; while the disposition spreads in Table 8.2 are weighted by number of shares. Results from these two tables are very similar.
} 
higher risk than funds with lower risk. Consistent with Chevalier and Ellison (1996), we find that the level of flow is lower for older funds. We also find that individual fund flows are positively related to flows to the category to which the fund belongs. This evidence is consistent with Sirri and Tufano (1998) and Huang, et al. (2006). Finally, the negative relationship between fund flow and total fee found in the early two sub-sample period is consistent with the results in Sirri and Tufano (1998). However, the coefficient becomes significantly positive in the last sample period. There is no consistent relationship between fund flow and total fee in this study. Huang et al (2005) document the similar results.

We also estimate regressions for model (8) but excluding performance in order to compare the impact of the disposition effect on flows through performance. After excluding performance, all coefficients for the disposition spread becomes more significantly negative. This result suggests that the negative relationship between the disposition effect and fund flows is partly due to the similar negative relationship between the disposition effect and fund performance.

The results for model (8) corroborate the results from model (7). The coefficients on the interactive terms are mostly negative, but not statistically significant. ${ }^{13}$ The negative coefficient implies that controlled for performance, the disposition spread has a negative impact on inflows. The impact of the disposition effect is stronger in the low and high performance categories. Regressions for the three subperiods support these conclusions.

\section{Controlled for Tax Overhang}

Tax overhang is a measure of unrealized capital gains that a fund carries from one period to the next. Overhang can negatively affect new shareholders because the tax consequences would be borne by the new shareholders if the fund decides to realize a substantial part of the unrealized capital gains. Using this line of reasoning, Barclay et al. (1998) model and find that funds with a high tax overhang attract smaller flows than funds with a lower tax overhang.

\footnotetext{
${ }^{13}$ In the tests using disposition spreads weighted by number of shares, the coefficients on the interactive terms are mostly significantly negative.
} 
Like tax overhang, the disposition effect is a measure of how quickly the capital gains are realized. Funds that exhibit a high degree of disposition effect are likely to retain smaller unrealized capital gains implying that they have a smaller tax overhang. On the other hand, non-disposition oriented funds are likely to hold much larger unrealized capital gains implying that they have larger tax overhang. Thus, based on Barclay, et al. (1998) results, disposition oriented funds should have large inflows since they have a smaller tax overhang than non-disposition oriented funds. This is contrary to the results reported in the previous subsection.

In this subsection, we examine the interactive relationships between flows, tax overhang and disposition effect. The results on the direct relationship between flows and tax overhang are reported in Panel A of Table 9. To test the relationship at an aggregate level, funds are firstly grouped into High, Medium and Low performance group as we do in earlier tests. Within each performance group, funds are divided into quintiles by tax overhang. Funds in the top quintile have the highest overhang, and funds in the bottom quintile have the lowest overhang.

There are a few interesting findings. First, not surprisingly, funds in the High performance group enjoy higher level of flows than funds in the Medium and the Low performance group. This finding is consistent with what we find in the previous sections and what has been documented in the literature.

Second, within each performance group, funds in the low tax overhang group have significantly higher level of flows than funds in the high tax overhang group. This finding is consistent with Barclay, et al(1998)'s argument that funds with low tax overhang expose investors to smaller present value of future tax liabilities and therefore attract more money from new investors. Furthermore, when we look at the flow difference between low tax overhang and high tax overhang funds, the difference is most prominent in the period of 1987-97 when the capital gains tax rate is high. This finding is consistent with the notion that investors are more sensitive to tax consequence when tax rate is high. We conduct the similar tests at more detailed level by dividing funds into performance deciles, and further into tax overhang quintiles within each performance decile. The results are reported in Panel B of Table 9. We find the similar results as we observe in Panel A. 
We further examine if disposition effect can still explain the cross-sectional difference in flows after controlling for tax overhang and performance. In Table 10 Panel $\mathrm{B}$, funds are grouped into deciles by tax overhang. Within each tax overhang deciles, the funds are divided into high disposition effect funds and low disposition effect funds. To test the relationship at a more aggregate level, funds in the bottom 2 overhang deciles are grouped into Low overhang group, funds in the middle 6 overhang deciles are grouped into Medium overhang group, and funds in the top 2 deciles are grouped into High overhang group. It can be seen from Table 10 that in almost all cases, the flows are larger for the low disposition effect funds than for the high disposition effect funds. The difference in flows is largest for the period of 1987-1997 when the capital gains tax rate is high. The hypothesis is retested by controlling for performance in Table 11. Once again, we find that high disposition effect funds have smaller flows than low disposition effect funds. Thus, fund flows depend on the disposition orientation of mutual funds. Earlier findings regarding the relationship between performance and flows and the relationship between tax overhang and flows also exist in Tables 10 and 11.

We further test the interactive relationships between flows, tax overhang and disposition effect through regression analysis. We run the regression model (8) with tax overhang as an additional control variable. Results are reported in Table 12. What emerges from Table 12 is that the disposition effect still affects fund flows after performance and tax overhang are controlled for, which is consistent with the results of univariate analyses. However, there are some puzzles about tax overhang in the regression results. First, the coefficient for tax overhang is negative but insignificant for the whole sample period and the first two sub-sample periods. Second, the coefficient becomes significantly positive in the last sample period. These results are different from what documented in Barclay et al (1998) and Bergstresser and Poterba (2002). The difference may arise for a few reasons including different samples and different control variables included in the regression model. What we can conclude is that the effect of tax overhang on fund flows is inconclusive given the mixed evidence, but fund performance and the disposition effect influence fund flows significantly. 


\section{Discussion}

Mutual fund managers are professional traders, and supposed to have superior ability to identify mispriced securities and trade rationally. However, we find that a significant proportion of equity fund managers exhibit various degrees of the disposition effect, and this behavior hurts fund performance and fund flows. These findings naturally lead to an interesting and important question: why do fund managers behave seemingly irrationally like individual investors? Although empirical examination of this question is beyond the scope of this study, we would like to discuss several potential explanations and provide some insight for future research in this area.

In a rational expectations framework, a fund manager may sell winners to keep the portfolio well balanced. One of the advantages that mutual funds offer individual investors is diversification. Modern portfolio theory suggests that diversification can be achieved by holding optimal portfolios. Given a certain number of assets with various degrees of risk, there are optimal weights for assets such that the portfolio is efficient. To apply the modern portfolio theory in practice, a fund manager needs to periodically rebalance the portfolio by resetting asset allocation when the allocation deviates from the optimum due to changes of assets' values. Specifically, winner assets can be overweight due to the value appreciation, while loser assets can be underweight due to the value depreciation. To keep the portfolio optimal, fund managers will sell winner assets and hold onto loser assets.

A fund manager may also sell winners when the fund experiences a large redemption. A large redemption could happen when fund investors have liquidity demands or maybe because investors want to punish past poor performance. In either case, fund managers are forced to engage in a material volume of liquidity-motivated trading and selling winners rather losers is less costly.

There are other rational reasons possibly justifying why a fund manager may sell winners. One reason could be that a manager is informed of some good investment ideas and he believes that the new investment will outperform current winners. The other reason could be that a manager wants to attract money from new investor by lowering current tax overhang. However, these two conjectures are rejected by the evidence that 
disposition prone funds perform poorly and experience lower level of flows compared to other funds that are not disposition oriented.

Like individual investors, fund managers may commit the disposition effect because they are subject to irrational decision-making process. The prospect theory, a decision-making theory proposed by Kahneman and Tversky (1979), is the most appealing argument for the disposition effect over the past 20 years. The theory posits that investors process gains and losses using a value function that is concave in the region of gains and convex in the region of losses. The implications are that investors are risk averse over gains, and therefore they are inclined to sell stocks that have appreciated since purchase. On the other hand, investors are risk-seeking over losses, and inclined to hold on to a stock that is trading at a loss. However, this theory is difficult to be formally tested.

This behavior bias may also arise because of managers' psychological unwillingness to admit past mistakes. Scherbina and Jin (2005) show that new fund managers, who are emotionally unattached to their predecessors' decisions, sell the momentum losers they have inherited more readily than continuing fund managers. Managers are reluctant to realize losses also possibly because they believe that today's losers will soon outperform today's winners. However, it is difficult to distinguish between this irrational belief in mean reversion, the psychological reason, and the prospect theory.

It is surprising to find that some fund managers are disposition prone. The

challenge after this finding is to figure out the real motivation behind this behavior. This task will also help to evaluate fund managers' ability more properly.

\section{Conclusion}

Suboptimal disposition behavior among individual investors has been documented by Shefrin and Statman (1985), Odean (1998) and by many other researchers. Recently, Frazzini (2006) and Cici (2006) have found evidence of this kind of behavior in mutual fund managers. 
The underlying question in much of this research is whether the personal characteristics of individual or institutional investors can introduce persistent biases in security prices and whether the efficient markets hypothesis needs to be rewritten with a behavioral slant. It has been easy for believers in efficient capital markets to belittle the influence of individual investors based on the claim that smart, institutional investors will drive irrational individual investors out of the market, notwithstanding DeLong, Shleifer, Summers, and Waldmann (1990). However, the disposition orientation among institutional investors has more serious implications. If both individual and institutional investors suffer from these behavioral biases, then who are the smart investors responsible for driving out the inefficiencies?

The results in this paper shed light on this important question. We find that the average mutual fund manager is not disposition prone. In fact, the average mutual fund manager is more likely to realize losses before capital gains. Besides the effect on performance, the manager is also cognizant of the tax implications of her trades for the shareholders. Nonetheless, there exists a large minority of fund managers who do sell their winners too quickly while holding on to their losers. Can't these large institutional investors survive and affect prices in a nontrivial way? While we don't have a handle on the transitory effect on prices, we find that disposition oriented funds sport poor performance and attract smaller inflows. In this respect, individual investors seem to be smart in picking tax-efficient funds with sustainable good performance. It would be reasonable to conjecture that, over a period of time, the disposition oriented funds are likely to shrivel and die. Thus, while institutional investors may overwhelm irrational individual investors, individual investors in turn discipline behaviorally oriented institutional managers leaving security prices largely unbiased. 


\section{References}

Barber, B.M., T. Odean, and L. Zheng, 2002, Out of Sight, Out of Mind: The Effects of Expenses on Mutual Fund Flows, Journal of Business, forthcoming.

Barber, Brad M. and Terrance Odean, 2003. Are individual investors tax savvy? Evidence from retail and discount brokerage accounts. Journal of Public Economics 88, 419-42.

Barberis, Nicholas, and Ming Huang, 2001, Mental accounting, loss aversion, and individual stock returns, Journal of Finance 56, 1247-1292

Barberis, Nicholas, and Wei Xiong, 2006, What drives the disposition effect? An analysis of a long-standing preference-based explanation, Working Paper

Barclay, Michael J., Neil D. Pearson, and Michael S. Weisbach, 1998, Open-end mutual funds and capital-gains taxes, Journal of Financial Economics 49, 3-43

Bergstresser, D., and J. Poterba, 2002, Do After-Tax Returns Affect Mutual Fund Inflows? Journal of Financial Economics, 63, 381-414.

Berk, J.B., and R.C. Green, 2004, Mutual Fund Flows and Performance in Rational Markets, Journal of Political Economy, forthcoming.

Bollen, Nicolas, and Jeffrey Busse, 2005, Short-term persistence in mutual fund performance, Review of Financial Studies 18, 569-597

Brown, Stephen, and William Goetzmann, 1995, Attrition and mutual fund performance, Journal of Finance 50, 679-698

Carhart, Mark M., 1997, On persistence in mutual fund performance, Journal of Finance 52, 57-82.

Case, Karl, and Robert Shiller, 1988, The behavior of home buyers in boom and post boom markets, New England Economic Review, 29-46

Chen, Hsiu-Lang, Narasimhan Jegadeesh, and Russ Wermers, 2000, The value of active mutual fund management: An examination of the stockholdings and trades of fund managers, Journal of Financial \& Quantitative Analysis 35, 343-368.

Chen, Joseph, and Harrison Hong, Ming Huang and Jeffrey D. Kubik, 2004, Does fund size erode mutual fund performance? The role of liquidity and organization, American Economic Review 94, 1276-1302.

Chevalier, J., and G. Ellison, 1997, Risk Taking by Mutual Funds as a Response to Incentives, Journal of Political Economy, 105, 1167-1200.

Cici, Gjergji, 2006, The relation of the disposition effect to mutual fund trades and performance, Working Paper

Constantinides, G. M., 1983. Optimal stock trading with personal taxes. Econometrica 51, 611-36.

Constantinides, George, 1984, Optimal stock trading with personal taxes, Journal of Financial Economics 13, 65-89. 
Coval, Joshua D., and Tyler Shumway, 2001, Do behavioral biases affect prices? Working Paper, University of Michigan.

Dammon, R. M., Spatt, C. S., and H.H. Zhang, 2001, Optimal consumption and investment with capital gains taxes, Review of Financial Studies 14, 583-616.

Droms, Willian G. and David A. Walker, 1994, Investment performance of international mutual funds, Journal of Financial Research, 17, 1-14

Edelen, Roger M., 1999, Investor flows and the assessed performance of open-end mutual funds, Journal of Financial Economics 53, 439-466.

Elton, Edwin J., Martin J. Gruber, Sanjiv Das, and Matthew Hlavka, 1993, Efficiency with costly information: A reinterpretation of evidence from managed portfolios, Review of Financial Studies, 6, 1-22.

Fama, E. F. and K. R. French, 1992. The cross-section of expected stock returns. Journal of Finance 47, 427-65.

Fama, Eugene F., and Kenneth R. French, 1993, Common risk factors in the returns on stocks and bonds, Journal of Financial Economics 33, 3-56.

Fama, Eugene, and James MacBeth, 1973, Risk, return, and equilibrium: Empirical tests, Journal of Political Economy 81, 607 - 636.

Frazzini, Andrea, 2006, The disposition effect and under-reaction to news, Journal of Finance, Forthcoming.

Galaher, S., R. Kaniel, and L. Starks, 2004, Mutual funds and advertising, Working Paper.

Genesove, David, and Christopher Mayer, 2001, "Loss aversion and seller behavior: Evidence from the housing market, NBER Working Paper 8143.

Gibson, Scott, Assem Safieddine and Sheridan Titman, 2000, Tax-motivated trading and price pressure: An analysis of mutual fund holdings, Journal of Financial and Quantitative Analysis 35, 369-86.

Grinblatt, Mark, and Bing Han, 2005, Prospect theory, mental accounting, and momentum, Journal of Financial Economics 78, 311-339.

Grinblatt, Mark, and Matti Keloharju, 2001, What Makes Investors Trade?, Journal of Finance 56, 589-616.

Grinblatt, Mark, and Sheridan Titman, 1992, The persistence of mutual fund performance, Journal of Finance 47, 1977-1984

Grinblatt, Mark, and Sheridan Titman, 1994, A study of monthly fund returns and performance evaluation techniques, Journal of Financial and Quantitative Analysis 29, 419-444.

Gruber, M.J., 1996, Another Puzzle: The Growth in Actively Managed Mutual Funds, Journal of Finance, 51, 783-810.

Haigh, Michael and List, John, 2004, Do Professional Traders Exhibit Myopic Loss Aversion? An Experimental Analysis, Journal of Finance, forthcoming. 
Hendricks, Darryl, Jay Patel, and Richard Zeckhauser, 1993, Hot hands in mutual funds: short-run persistence of performance, 1974-1988, Journal of Finance 48, 93-130

Huang, Jennifer, Kelsey Wei and Hong Yan, 2006, Participation costs and the sensitivity of fund flows to past performance, Journal of Finance, forthcoming.

Huddart, Steve. and V. Narayanan, 2002. An empirical examination of tax factors and mutual funds' stock sales decisions. Review of Accounting Studies, 7(2/3): 319341.

Ibbotson, Roger, and William Goetzmann, 1994, Do winners repeat? Journal of Portfolio Management 20, 9-18

Investment Company Institute, 2005, The Mutual Fund Fact Book, Investment Company Institute, Washington, DC.

Ippolito, R.A., 1992, Consumer Reaction to Measures of Poor Quality: Evidence from the Mutual Fund Industry, Journal of Law and Economics, 35, 45-70.

Ippolito, Roger A., 1989, Efficiency with costly information: A study of mutual fund performance, Quarterly Journal of Economics, 104, 1-23.

Jain, P.C., and J.S. Wu, 2000, Truth in Mutual Fund Advertising: Evidence on Future Performance and Fund Flows, Journal of Finance, 55, 937-958.

Jegadeesh, Narasimhan, and Sheridan Titman, 1993, Returns to buying winners and selling losers: Implications for stock market efficiency, Journal of Finance 48, 65-91.

Jin, Li, 2005. Capital gain tax overhang and price pressure. Journal of Finance, forthcoming.

Kahneman, Daniel, and Amos Tversky, 1979, Prospect Theory: An analysis of decision under risk, Econometrica 47, 263-291.

Khorana, A., and H. Servaes, 2004, Conflicts of Interest and Competition in the Mutual Fund Industry, Working Paper.

Locke, Peter, and Steven S. Mann, 1999, Do professional traders exhibit loss aversion?, working paper, Texas Christian University

Lynch, A., and D. Musto, 2003, How Investors Interpret Past Fund Returns, Journal of Finance, 58, 2033-2058.

Massa, M., 2003, How Do Family Strategies Affect Fund Performance? When Performance-Maximization Is Not the Only Game in Town, Journal of Financial Economics, 67, 249-304.

Nanda, V., Z. Wang and L. Zheng, 2004a, Family Values and the Star Phenomenon: Strategies of Mutual Fund Families, Review of Financial Studies, 17, 667-698.

Odean, Terrance, 1998, Are investors reluctant to realize their losses? Journal of Finance 53, 1775-1798.

Poterba, J., 1999. Unrealized capital gains and the measurement of after-tax portfolio performance. Journal of Private Portfolio Management 1, 23-34. 
Poterba, J., and Andrew Samwick, 2002. Taxation and household portfolio composition: US evidence from the 1980s and 1990s. Journal of Public Economics 87, 5-38.

Poterba, J., and J. Weisbenner (2001). Capital gains tax rules, tax-loss selling, and the turn-of-the-year returns. Journal of Finance 56, 353-368.

Scherbina, Anna and Jin, Li, 2005, Change is good or the disposition effect among mutual fund managers, Working Paper, Harvard University.

Shapira, Zur and Itzhak Venezia, 2001, Patterns of behavior of professionally managed and independent investors, Journal of Banking and Finance 25(8), 1573-87.

Shefrin, Hersh, and Meir Statman, 1985, The disposition to sell winners too early and ride losers too long: Theory and evidence, Journal of Finance 40, 777-790.

Sirri, E.R., and P. Tufano, 1998, Costly Search and Mutual Fund Flows, Journal of Finance, 53, 1589-1622.

Weber, Martin, and Colin Camerer, 1998, The disposition effect in securities trading: An experimental analysis, Journal of Economic Behavior and Organization 33, 167184.

Wermers, Russ, 2000, Mutual fund performance: An empirical decomposition into stockpicking talent, style, transactions costs, and expenses, Journal of Finance 55, 1655-1695

Wermers, Russell, 2003, Is money really "smart"? New evidence on the relation between mutual fund flows, manager behavior, and performance persistence, Working Paper, University of Maryland. 


\section{Table 1: Fund Characteristics}

Characteristics of the 1,960 U.S. equity mutual funds in the sample for selected years between 1980 and 2004 are given below. Means and medians (in brackets) at the end of each year are reported for the total net assets (in millions), expense ratio, annual turnover, and the total load. In addition, information about taxes on capital gains is provided. The last column lists the number of funds included in the sample each year.

\begin{tabular}{|c|c|c|c|c|c|c|c|}
\hline $\begin{array}{c}\text { Year } \\
\text { (as of end of } \\
\text { the year) }\end{array}$ & $\begin{array}{l}\text { Total Net } \\
\text { Assets } \\
\text { (Millions) }\end{array}$ & Expense Ratio & $\begin{array}{l}\text { Annual } \\
\text { Turnover }\end{array}$ & Total Load & $\begin{array}{c}\text { Maximum Tax } \\
\text { Rate on Long } \\
\text { Term Gains }\end{array}$ & $\begin{array}{l}\text { Long-Term } \\
\text { Holding Period } \\
\text { (Months) }\end{array}$ & $\begin{array}{l}\text { Number of } \\
\text { Funds }\end{array}$ \\
\hline 1980 & $\begin{array}{l}138 \\
{[52]}\end{array}$ & $\begin{array}{c}1.01 \% \\
{[0.93 \%]}\end{array}$ & $\begin{array}{c}77 \% \\
{[55 \%]}\end{array}$ & $\begin{array}{c}4.03 \% \\
{[3.25 \%]}\end{array}$ & $28 \%$ & 12 & 290 \\
\hline 1985 & $\begin{array}{l}223 \\
{[72]}\end{array}$ & $\begin{array}{c}0.88 \% \\
{[0.91 \%]}\end{array}$ & $\begin{array}{c}84 \% \\
{[65 \%]}\end{array}$ & $\begin{array}{c}2.91 \% \\
{[0.00 \%]}\end{array}$ & $20 \%$ & 6 & 441 \\
\hline 1990 & $\begin{array}{l}256 \\
{[56]}\end{array}$ & $\begin{array}{c}1.16 \% \\
{[1.11 \%]}\end{array}$ & $\begin{array}{c}89 \% \\
{[61 \%]}\end{array}$ & $\begin{array}{c}2.39 \% \\
{[0.00 \%]}\end{array}$ & $28 \%$ & 12 & 706 \\
\hline 1995 & $\begin{array}{l}599 \\
{[86]}\end{array}$ & $\begin{array}{c}1.33 \% \\
{[1.22 \%]}\end{array}$ & $\begin{array}{c}89 \% \\
{[64 \%]}\end{array}$ & $\begin{array}{c}2.06 \% \\
{[0.00 \%]}\end{array}$ & $28 \%$ & 12 & 1268 \\
\hline 2000 & $\begin{array}{l}1140 \\
{[152]}\end{array}$ & $\begin{array}{c}1.32 \% \\
{[1.21 \%]}\end{array}$ & $\begin{array}{l}102 \% \\
{[78 \%]}\end{array}$ & $\begin{array}{c}1.98 \% \\
{[0.00 \%]}\end{array}$ & $20 \%$ & 12 & 1628 \\
\hline 2004 & $\begin{array}{l}1603 \\
{[238]}\end{array}$ & $\begin{array}{c}1.39 \% \\
{[1.25 \%]}\end{array}$ & $\begin{array}{c}89 \% \\
{[62 \%]}\end{array}$ & $\begin{array}{c}2.12 \% \\
{[0.00 \%]}\end{array}$ & $15 \%$ & 12 & 1309 \\
\hline
\end{tabular}

Notes: 1 . The maximum tax rate on long-term gains was $28 \%$ for $1979-1981,20 \%$ for $1981-1986,28 \%$ for $1987-1997,20 \%$ for $1997-2002$, and 15\% since 2003. Midyear rate changes occurred in 1981, 1997 and 2003.

2. Prior to June 1984, gains and losses held for more than 12 months were classified as long term. Between June 1984 and December 1987, the long-term holding period was changed to 6 months. Since January 1988, the long-term holding period was raised to 12 months. 


\section{Table 2: Estimates of the Disposition Spread}

This table contains estimates of the proportion of gains realized (PGR), the proportion of losses realized (PLR), and the disposition spread measured as the difference between PGR and PLR. PGR is calculated as $P G R_{i, t}=\frac{R C G_{i, t}}{R C G_{i, t}+U C G_{i, t}}$ and PLR is calculated as $P L R_{i, t}=\frac{R C L_{i, t}}{R C L_{i, t}+U C L_{i, t}}$, where $R C G_{i, t}$ and $R C L_{i, t}$ are realized capital gains and losses and $U C G_{i, t}$ and $U C L_{i, t}$ are unrealized capital gains and losses for fund $i$ in quarter $t$. Capital gains and losses are measured under the assumption that mutual fund managers sell stocks with the highest basis first (HIFO). PGR, PLR and the disposition spread are calculated every quarter and the time-series means are calculated for each fund. Statistics in Panel A are value-weighted, whereas statistics in Panel B are weighted by the number of shares. $* * *$ denotes significance at $1 \%$ level.

\begin{tabular}{|c|c|c|c|}
\hline \multicolumn{4}{|c|}{ Panel A: Value-weighted Disposition Effect } \\
\hline & PGR & PLR & PGR-PLR \\
\hline \multicolumn{4}{|c|}{ All Quarters (N=1,960) } \\
\hline Mean & $25.8 \%$ & $43.8 \%$ & $-18.0 \% * * *$ \\
\hline Median & $24.2 \%$ & $42.2 \%$ & $-17.5 \% * * *$ \\
\hline Range & {$[0 \%, 100 \%]$} & {$[0 \%, 100 \%]$} & {$[-67.4 \%, 56.6 \%]$} \\
\hline \multicolumn{4}{|c|}{$1^{\text {st }}$ Quarter $(\mathrm{N}=1,756)$} \\
\hline Mean & $25.7 \%$ & $40.8 \%$ & $-15.1 \% * * *$ \\
\hline Median & $23.8 \%$ & $38.7 \%$ & $-14.2 \% * * *$ \\
\hline Range & {$[0 \%, 96.2 \%]$} & {$[0 \%, 100 \%]$} & {$[-90.2 \%, 61.8 \%]$} \\
\hline \multicolumn{4}{|c|}{$2^{\text {nd }}$ Quarter $(\mathrm{N}=1,827)$} \\
\hline Mean & $25.2 \%$ & $44.0 \%$ & $-18.7 \% * * *$ \\
\hline Median & $23.0 \%$ & $42.4 \%$ & $-18.2 \% * * *$ \\
\hline Range & {$[0 \%, 93.1 \%]$} & {$[0 \%, 100 \%]$} & {$[-90.3 \%, 57.9 \%]$} \\
\hline \multicolumn{4}{|c|}{$3^{\text {rd }}$ Quarter $(\mathrm{N}=1,791)$} \\
\hline Mean & $23.0 \%$ & $40.0 \%$ & $-17.0 \% * * *$ \\
\hline Median & $21.1 \%$ & $37.9 \%$ & $-15.7 \% * * *$ \\
\hline Range & {$[0 \%, 100 \%]$} & {$[0 \%, 100 \%]$} & {$[-99.0 \%, 51.3 \%]$} \\
\hline \multicolumn{4}{|c|}{$4^{\text {th }}$ Quarter $(N=1,875)$} \\
\hline Mean & $25.6 \%$ & $44.3 \%$ & $-18.7 \% * * *$ \\
\hline Median & $23.6 \%$ & $42.9 \%$ & $-18.4 \% * * *$ \\
\hline Range & {$[0 \%, 100 \%]$} & {$[0 \%, 100 \%]$} & {$[-82.0 \%, 61.9 \%]$} \\
\hline
\end{tabular}




\begin{tabular}{|c|c|c|c|}
\hline \multicolumn{4}{|c|}{ Panel B: Disposition Effect weighted by the Number of Shares } \\
\hline & PGR & PLR & PGR-PLR \\
\hline \multicolumn{4}{|c|}{ All Quarters (N=1,960) } \\
\hline Mean & $43.1 \%$ & $48.7 \%$ & $-5.6 \% * * *$ \\
\hline Median & $42.8 \%$ & $48.4 \%$ & $-5.1 \% * * *$ \\
\hline Range & {$[0 \%, 100 \%]$} & {$[0 \%, 100 \%]$} & {$[-63.6 \%, 47.7 \%]$} \\
\hline \multicolumn{4}{|c|}{$1^{\text {st }}$ Quarter $(\mathrm{N}=1,752)$} \\
\hline Mean & $43.4 \%$ & $47.1 \%$ & $-3.6 \% * * *$ \\
\hline Median & $42.8 \%$ & $46.5 \%$ & $-3.2 \% * * *$ \\
\hline Range & {$[0 \%, 100 \%]$} & {$[0 \%, 100 \%]$} & {$[-95.0 \%, 64.2 \%]$} \\
\hline \multicolumn{4}{|c|}{$2^{\text {nd }}$ Quarter $(\mathrm{N}=1,827)$} \\
\hline Mean & $42.5 \%$ & $48.1 \%$ & $-5.6 \% * * *$ \\
\hline Median & $42.0 \%$ & $47.7 \%$ & $-4.9 \% * * *$ \\
\hline Range & {$[0 \%, 100 \%]$} & {$[0 \%, 100 \%]$} & {$[-80.0 \%, 52.5 \%]$} \\
\hline \multicolumn{4}{|c|}{$3^{\text {rd }}$ Quarter $(\mathrm{N}=1,785)$} \\
\hline Mean & $40.7 \%$ & $45.7 \%$ & $-4.9 \% * * *$ \\
\hline Median & $40.2 \%$ & $45.3 \%$ & $-4.1 \% * * *$ \\
\hline Range & {$[0 \%, 100 \%]$} & {$[0 \%, 100 \%]$} & {$[-70.4 \%, 57.9 \%]$} \\
\hline \multicolumn{4}{|c|}{$4^{\text {th }}$ Quarter $(\mathrm{N}=1,852)$} \\
\hline Mean & $43.4 \%$ & $49.9 \%$ & $-6.4 \% * * *$ \\
\hline Median & $43.0 \%$ & $50.0 \%$ & $-5.8 \% * * *$ \\
\hline Range & {$[0 \%, 100 \%]$} & {$[0 \%, 100 \%]$} & {$[-55.0 \%, 50.0 \%]$} \\
\hline
\end{tabular}




\section{Table 3.1: Disposition Effect by Deciles - Value-weighted Disposition Spread}

This table summarizes characteristics of equally-weighted deciles of the disposition spread weighted by dollar value. The portfolio formation period is one quarter or one year. Each quarter and within each investment category, funds are ranked into deciles based on their disposition spreads in the previous quarter or their average disposition spreads over the past four quarters. Funds in decile 10 have the highest disposition spread and funds in decile 1 have the lowest (or most negative) disposition spread. The first number in each cell is the decile mean and the second number in each cell is the decile median.

\begin{tabular}{|c|c|c|c|c|c|c|}
\hline \multicolumn{7}{|c|}{ Panel A: Portfolio Formation Period is 1 Quarter } \\
\hline $\begin{array}{l}\text { Disposition } \\
\text { Deciles }\end{array}$ & $\begin{array}{l}\text { Disposition } \\
\text { Spread }\end{array}$ & $\begin{array}{l}\text { Total Net } \\
\text { Assets } \\
\text { (\$ million) }\end{array}$ & $\begin{array}{c}\text { Expense } \\
\text { Ratio }\end{array}$ & Turnover & $\begin{array}{l}\text { Past 12- } \\
\text { Month } \\
\text { Return }\end{array}$ & $\begin{array}{c}\text { Past 12- } \\
\text { Month } \\
\text { Volatility }\end{array}$ \\
\hline \multirow[t]{2}{*}{1} & $-64.1 \%$ & 573 & $1.22 \%$ & $92 \%$ & $17.2 \%$ & 4.76 \\
\hline & $-63.8 \%$ & 481 & $1.27 \%$ & $90 \%$ & $19.7 \%$ & 4.32 \\
\hline \multirow[t]{2}{*}{2} & $-45.0 \%$ & 741 & $1.15 \%$ & $94 \%$ & $15.7 \%$ & 4.83 \\
\hline & $-44.6 \%$ & 580 & $1.21 \%$ & $91 \%$ & $17.0 \%$ & 4.58 \\
\hline \multirow[t]{2}{*}{3} & $-33.7 \%$ & 733 & $1.15 \%$ & $92 \%$ & $15.0 \%$ & 4.81 \\
\hline & $-32.6 \%$ & 564 & $1.21 \%$ & $90 \%$ & $15.4 \%$ & 4.62 \\
\hline \multirow[t]{2}{*}{4} & $-24.9 \%$ & 765 & $1.14 \%$ & $89 \%$ & $14.6 \%$ & 4.84 \\
\hline & $-23.9 \%$ & 554 & $1.22 \%$ & $89 \%$ & $14.9 \%$ & 4.66 \\
\hline \multirow[t]{2}{*}{5} & $-17.4 \%$ & 787 & $1.11 \%$ & $83 \%$ & $14.1 \%$ & 4.81 \\
\hline & $-15.8 \%$ & 651 & $1.19 \%$ & $81 \%$ & $14.7 \%$ & 4.68 \\
\hline \multirow[t]{2}{*}{6} & $-10.8 \%$ & 773 & $1.09 \%$ & $75 \%$ & $13.7 \%$ & 4.74 \\
\hline & $-9.3 \%$ & 669 & $1.18 \%$ & $76 \%$ & $13.9 \%$ & 4.49 \\
\hline \multirow[t]{2}{*}{7} & $-4.9 \%$ & 792 & $1.07 \%$ & $70 \%$ & $13.5 \%$ & 4.70 \\
\hline & $-3.0 \%$ & 551 & $1.16 \%$ & $68 \%$ & $14.1 \%$ & 4.57 \\
\hline \multirow[t]{2}{*}{8} & $0.7 \%$ & 768 & $1.12 \%$ & $64 \%$ & $13.9 \%$ & 4.68 \\
\hline & $1.2 \%$ & 554 & $1.16 \%$ & $65 \%$ & $13.2 \%$ & 4.56 \\
\hline \multirow[t]{2}{*}{9} & $7.7 \%$ & 609 & $1.14 \%$ & $67 \%$ & $13.7 \%$ & 4.64 \\
\hline & $7.4 \%$ & 460 & $1.18 \%$ & $66 \%$ & $14.3 \%$ & 4.36 \\
\hline \multirow[t]{2}{*}{10} & $23.9 \%$ & 353 & $1.33 \%$ & $93 \%$ & $12.5 \%$ & 4.67 \\
\hline & $23.2 \%$ & 276 & $1.34 \%$ & $87 \%$ & $12.4 \%$ & 4.26 \\
\hline
\end{tabular}




\begin{tabular}{|c|c|c|c|c|c|c|}
\hline \multicolumn{7}{|c|}{ Panel B: Portfolio Formation Period is 1 Year } \\
\hline $\begin{array}{l}\text { Disposition } \\
\text { Deciles }\end{array}$ & $\begin{array}{l}\text { Disposition } \\
\text { Spread }\end{array}$ & $\begin{array}{l}\text { Total Net } \\
\text { Assets } \\
\text { (\$ million) }\end{array}$ & $\begin{array}{c}\text { Expense } \\
\text { Ratio }\end{array}$ & Turnover & $\begin{array}{l}\text { Past 12- } \\
\text { Month } \\
\text { Return }\end{array}$ & $\begin{array}{l}\text { Past 12- } \\
\text { Month } \\
\text { Volatility }\end{array}$ \\
\hline \multirow[t]{2}{*}{1} & $-52.4 \%$ & 710 & $1.22 \%$ & $96 \%$ & $17.0 \%$ & 4.88 \\
\hline & $-52.8 \%$ & 576 & $1.27 \%$ & $96 \%$ & $18.6 \%$ & 4.51 \\
\hline \multirow[t]{2}{*}{2} & $-37.4 \%$ & 761 & $1.16 \%$ & $94 \%$ & $15.6 \%$ & 4.92 \\
\hline & $-377.3 \%$ & 560 & $1.19 \%$ & $93 \%$ & $17.9 \%$ & 4.68 \\
\hline \multirow[t]{2}{*}{3} & $-29.6 \%$ & 713 & $1.17 \%$ & $90 \%$ & $15.0 \%$ & 4.86 \\
\hline & $-29.1 \%$ & 608 & $1.22 \%$ & $91 \%$ & $16.4 \%$ & 4.59 \\
\hline \multirow[t]{2}{*}{4} & $-23.6 \%$ & 797 & $1.14 \%$ & $83 \%$ & $15.0 \%$ & 4.87 \\
\hline & $-22.8 \%$ & 616 & $1.20 \%$ & $84 \%$ & $15.7 \%$ & 4.61 \\
\hline \multirow[t]{2}{*}{5} & $-18.4 \%$ & 763 & $1.13 \%$ & $83 \%$ & $14.5 \%$ & 4.86 \\
\hline & $-17.1 \%$ & 538 & $1.20 \%$ & $80 \%$ & $15.1 \%$ & 4.66 \\
\hline \multirow[t]{2}{*}{6} & $-13.7 \%$ & 799 & $1.11 \%$ & $76 \%$ & $14.5 \%$ & 4.83 \\
\hline & $-12.5 \%$ & 591 & $1.17 \%$ & $76 \%$ & $14.3 \%$ & 4.58 \\
\hline \multirow[t]{2}{*}{7} & $-9.19 \%$ & 798 & $1.10 \%$ & $72 \%$ & $13.5 \%$ & 4.72 \\
\hline & $-7.66 \%$ & 629 & $1.17 \%$ & $72 \%$ & $14.3 \%$ & 4.62 \\
\hline \multirow[t]{2}{*}{8} & $-4.41 \%$ & 685 & $1.12 \%$ & $68 \%$ & $13.1 \%$ & 4.68 \\
\hline & $-3.35 \%$ & 545 & $1.19 \%$ & $69 \%$ & $13.8 \%$ & 4.50 \\
\hline \multirow[t]{2}{*}{9} & $1.58 \%$ & 546 & $1.15 \%$ & $70 \%$ & $13.2 \%$ & 4.66 \\
\hline & $2.22 \%$ & 409 & $1.19 \%$ & $71 \%$ & $13.9 \%$ & 4.42 \\
\hline \multirow[t]{2}{*}{10} & $15.0 \%$ & 355 & $1.41 \%$ & $94 \%$ & $11.9 \%$ & 4.75 \\
\hline & $15.3 \%$ & 265 & $1.39 \%$ & $93 \%$ & $13.3 \%$ & 4.35 \\
\hline
\end{tabular}




\section{Table 3.2: Disposition Effect by Deciles - Number-of-shares Weighted Disposition Spread}

This table summarizes characteristics of equally-weighted deciles of the disposition spread weighted by number of shares. The portfolio formation period is one quarter or one year. Each quarter and within each investment category, funds are ranked into deciles based on their disposition spreads in the previous quarter or their average disposition spreads over the past four quarters. Funds in decile 10 have the highest disposition spread and funds in decile 1 have the lowest (or most negative) disposition spread. The first number in each cell is the decile mean and the second number in each cell is the decile median.

\begin{tabular}{|c|c|c|c|c|c|c|}
\hline \multicolumn{7}{|c|}{ Panel A: Portfolio Formation Period is 1 Quarter } \\
\hline $\begin{array}{l}\text { Disposition } \\
\text { Deciles }\end{array}$ & $\begin{array}{l}\text { Disposition } \\
\text { Spread }\end{array}$ & $\begin{array}{l}\text { Total Net } \\
\text { Assets } \\
\text { (\$ million) }\end{array}$ & $\begin{array}{c}\text { Expense } \\
\text { Ratio }\end{array}$ & Turnover & $\begin{array}{l}\text { Past 12- } \\
\text { Month } \\
\text { Return }\end{array}$ & $\begin{array}{l}\text { Past 12- } \\
\text { Month } \\
\text { Volatility }\end{array}$ \\
\hline \multirow[t]{2}{*}{1} & $-43.5 \%$ & 536 & $1.25 \%$ & $94 \%$ & $16.5 \%$ & 4.88 \\
\hline & $-42.4 \%$ & 394 & $1.29 \%$ & $94 \%$ & $18.2 \%$ & 4.61 \\
\hline \multirow[t]{2}{*}{2} & $-25.7 \%$ & 742 & $1.17 \%$ & $95 \%$ & $15.7 \%$ & 4.86 \\
\hline & $-24.7 \%$ & 534 & $1.22 \%$ & $93 \%$ & $16.5 \%$ & 4.62 \\
\hline \multirow[t]{2}{*}{3} & $-17.3 \%$ & 706 & $1.17 \%$ & $89 \%$ & $15.2 \%$ & 4.82 \\
\hline & $-17.0 \%$ & 524 & $1.23 \%$ & $89 \%$ & $15.8 \%$ & 4.56 \\
\hline \multirow[t]{2}{*}{4} & $-11.2 \%$ & 767 & $1.12 \%$ & $87 \%$ & $14.4 \%$ & 4.81 \\
\hline & $-10.9 \%$ & 603 & $1.21 \%$ & $88 \%$ & $14.9 \%$ & 4.58 \\
\hline \multirow[t]{2}{*}{5} & $-6.1 \%$ & 796 & $1.10 \%$ & $79 \%$ & $14.8 \%$ & 4.76 \\
\hline & $-6.3 \%$ & 622 & $1.17 \%$ & $80 \%$ & $15.1 \%$ & 4.57 \\
\hline \multirow[t]{2}{*}{6} & $-1.6 \%$ & 836 & $1.09 \%$ & $75 \%$ & $14.1 \%$ & 4.68 \\
\hline & $-1.7 \%$ & 747 & $1.17 \%$ & $74 \%$ & $14.4 \%$ & 4.47 \\
\hline \multirow[t]{2}{*}{7} & $2.9 \%$ & 886 & $1.10 \%$ & $73 \%$ & $13.8 \%$ & 4.65 \\
\hline & $3.0 \%$ & 707 & $1.16 \%$ & $73 \%$ & $13.5 \%$ & 4.58 \\
\hline \multirow[t]{2}{*}{8} & $0.8 \%$ & 700 & $1.11 \%$ & $72 \%$ & $13.9 \%$ & 4.65 \\
\hline & $0.8 \%$ & 512 & $1.17 \%$ & $75 \%$ & $14.1 \%$ & 4.42 \\
\hline \multirow[t]{2}{*}{9} & $14.5 \%$ & 581 & $1.14 \%$ & $74 \%$ & $13.1 \%$ & 4.64 \\
\hline & $14.1 \%$ & 422 & $1.18 \%$ & $71 \%$ & $13.3 \%$ & 4.47 \\
\hline \multirow[t]{2}{*}{10} & $29.5 \%$ & 411 & $1.25 \%$ & $72 \%$ & $12.8 \%$ & 4.74 \\
\hline & $28.9 \%$ & 330 & $1.29 \%$ & $70 \%$ & $13.2 \%$ & 4.37 \\
\hline
\end{tabular}




\begin{tabular}{|c|c|c|c|c|c|c|}
\hline \multicolumn{7}{|c|}{ Panel B: Portfolio Formation Period is 1 Year } \\
\hline $\begin{array}{l}\text { Disposition } \\
\text { Deciles }\end{array}$ & $\begin{array}{l}\text { Disposition } \\
\text { Spread }\end{array}$ & $\begin{array}{l}\text { Total Net } \\
\text { Assets } \\
\text { (\$ million) }\end{array}$ & $\begin{array}{c}\text { Expense } \\
\text { Ratio }\end{array}$ & Turnover & $\begin{array}{l}\text { Past 12- } \\
\text { Month } \\
\text { Return }\end{array}$ & $\begin{array}{l}\text { Past 12- } \\
\text { Month } \\
\text { Volatility }\end{array}$ \\
\hline \multirow[t]{2}{*}{1} & $-33.9 \%$ & 608 & $1.28 \%$ & $98 \%$ & $16.8 \%$ & 5.05 \\
\hline & $-34.7 \%$ & 406 & $1.32 \%$ & $98 \%$ & $19.2 \%$ & 4.76 \\
\hline \multirow[t]{2}{*}{2} & $-20.7 \%$ & 708 & $1.20 \%$ & $96 \%$ & $15.3 \%$ & 4.98 \\
\hline & $-21.3 \%$ & 435 & $1.24 \%$ & $95 \%$ & $17.3 \%$ & 4.76 \\
\hline \multirow[t]{2}{*}{3} & $-14.5 \%$ & 782 & $1.16 \%$ & $89 \%$ & $15.3 \%$ & 4.90 \\
\hline & $-14.8 \%$ & 535 & $1.21 \%$ & $89 \%$ & $16.8 \%$ & 4.74 \\
\hline \multirow[t]{2}{*}{4} & $-9.9 \%$ & 764 & $1.15 \%$ & $86 \%$ & $14.5 \%$ & 4.82 \\
\hline & $-9.9 \%$ & 547 & $1.22 \%$ & $88 \%$ & $15.3 \%$ & 4.63 \\
\hline \multirow[t]{2}{*}{5} & $-6.1 \%$ & 760 & $1.11 \%$ & $81 \%$ & $14.1 \%$ & 4.81 \\
\hline & $-5.8 \%$ & 693 & $1.18 \%$ & $81 \%$ & $15.4 \%$ & 4.64 \\
\hline \multirow[t]{2}{*}{6} & $-2.7 \%$ & 806 & $1.10 \%$ & $75 \%$ & $14.2 \%$ & 4.72 \\
\hline & $-2.5 \%$ & 656 & $1.17 \%$ & $73 \%$ & $14.6 \%$ & 4.53 \\
\hline \multirow[t]{2}{*}{7} & $0.7 \%$ & 785 & $1.11 \%$ & $74 \%$ & $13.8 \%$ & 4.70 \\
\hline & $0.8 \%$ & 667 & $1.17 \%$ & $73 \%$ & $14.4 \%$ & 4.56 \\
\hline \multirow[t]{2}{*}{8} & $4.5 \%$ & 747 & $1.12 \%$ & $69 \%$ & $13.5 \%$ & 4.69 \\
\hline & $4.4 \%$ & 525 & $1.18 \%$ & $70 \%$ & $13.6 \%$ & 4.44 \\
\hline \multirow[t]{2}{*}{9} & $9.6 \%$ & 625 & $1.16 \%$ & $76 \%$ & $13.5 \%$ & 4.59 \\
\hline & $9.6 \%$ & 440 & $1.21 \%$ & $76 \%$ & $14.4 \%$ & 4.43 \\
\hline \multirow[t]{2}{*}{10} & $21.4 \%$ & 366 & $1.24 \%$ & $70 \%$ & $12.4 \%$ & 4.77 \\
\hline & $21.2 \%$ & 297 & $1.37 \%$ & $68 \%$ & $13.7 \%$ & 4.49 \\
\hline
\end{tabular}




\section{Table 4.1: Disposition Effect and Fund Performance - Value-weighted Disposition Spread}

This table reports the fund performance for each disposition spread decile, where the disposition spreads are weighted by dollar value. Disposition spread deciles are constructed based on formation periods of one quarter and one year. Each quarter and within each investment category, funds are ranked into deciles based on their disposition spreads in the previous quarter or their average disposition spreads over the past four quarters. Funds in decile 10 have the highest disposition spread and funds in decile 1 have the lowest (or most negative) disposition spread.

All returns are reported for the quarter immediately following the formation quarter(s). Monthly raw return for each decile portfolio is calculated by equally weighting monthly raw returns of the funds in that portfolio. The time-series means and medians of the portfolio monthly raw returns are reported in the second and third columns. Intercepts from 3-factor and 4-factor regression models are also reported as risk-adjsuted returns for each decile portfolio. Fund flows for the quarter immediately after the portfolio formation period are calculated as $F L_{i, t}=\frac{T N A_{i, t}-T N A_{i, t-1}\left(1+r_{i, t}\right)}{T N A_{i, t-1}}$, where $T N A_{i, t}$ is the total net assets of fund $i$ at the end of quarter $t$, and $r_{i, t}$ is the total return of fund $i$ in quarter $t$. Fund flows are equally weighted within each decile portfolio. T-statistics for means and p-values for medians and differences are reported in brackets. ${ }^{*},{ }^{* *}$, and $* * *$ denote significance at $10 \%, 5 \%$ and $1 \%$ level, respectively. 


\begin{tabular}{|c|c|c|c|c|c|c|}
\hline \multirow{2}{*}{$\begin{array}{l}\text { Disposition } \\
\text { Deciles }\end{array}$} & \multicolumn{2}{|c|}{ Monthly Raw Return } & \multirow{2}{*}{$\begin{array}{l}\text { 3-factor } \\
\text { alpha }\end{array}$} & \multirow{2}{*}{$\begin{array}{l}\text { 4-factor } \\
\text { alpha }\end{array}$} & \multicolumn{2}{|c|}{ Fund flows } \\
\hline & mean & median & & & mean & median \\
\hline \multicolumn{7}{|c|}{ Panel A Formation period is 1 quarter } \\
\hline 1 & $\begin{array}{c}1.35 \\
{[28.03]}\end{array}$ & $\begin{array}{c}1.54 \\
{[<.0001]}\end{array}$ & $\begin{array}{c}0.20 \\
{[3.08]}\end{array}$ & $\begin{array}{c}0.11 \\
{[1.53]}\end{array}$ & $\begin{array}{c}2.43 \\
{[16.51]}\end{array}$ & $\begin{array}{c}-0.02 \\
{[0.7105]}\end{array}$ \\
\hline 2 & $\begin{array}{c}1.15 \\
{[24.37]}\end{array}$ & $\begin{array}{c}1.36 \\
{[<.0001]}\end{array}$ & $\begin{array}{c}0.05 \\
{[0.88]}\end{array}$ & $\begin{array}{c}0.01 \\
{[0.10]}\end{array}$ & $\begin{array}{c}1.36 \\
{[10.37]}\end{array}$ & $\begin{array}{c}-0.49 \\
{[<.0001]}\end{array}$ \\
\hline 3 & $\begin{array}{c}1.09 \\
{[23.26]}\end{array}$ & $\begin{array}{c}1.32 \\
{[<.0001]}\end{array}$ & $\begin{array}{c}0.05 \\
{[0.97]}\end{array}$ & $\begin{array}{c}-0.02 \\
{[-0.24]}\end{array}$ & $\begin{array}{c}1.25 \\
{[9.66]}\end{array}$ & $\begin{array}{c}-0.53 \\
{[<.0001]}\end{array}$ \\
\hline 4 & $\begin{array}{c}1.02 \\
{[21.87]}\end{array}$ & $\begin{array}{c}1.25 \\
{[<.0001]}\end{array}$ & $\begin{array}{c}-0.01 \\
{[-0.19]}\end{array}$ & $\begin{array}{c}-0.03 \\
{[-0.46]}\end{array}$ & $\begin{array}{c}1.08 \\
{[8.60]}\end{array}$ & $\begin{array}{c}-0.53 \\
{[<.0001]}\end{array}$ \\
\hline 5 & $\begin{array}{c}0.99 \\
{[21.64]}\end{array}$ & $\begin{array}{c}1.28 \\
{[<.0001]}\end{array}$ & $\begin{array}{c}-0.03 \\
{[-0.63]}\end{array}$ & $\begin{array}{c}-0.03 \\
{[-0.49]}\end{array}$ & $\begin{array}{c}1.10 \\
{[8.55]}\end{array}$ & $\begin{array}{c}-0.51 \\
{[<.0001]}\end{array}$ \\
\hline 6 & $\begin{array}{c}0.93 \\
{[20.47]}\end{array}$ & $\begin{array}{c}1.23 \\
{[<.0001]}\end{array}$ & $\begin{array}{c}-0.06 \\
{[-0.95]}\end{array}$ & $\begin{array}{c}-0.03 \\
{[-0.39]}\end{array}$ & $\begin{array}{c}0.96 \\
{[7.73]}\end{array}$ & $\begin{array}{c}-0.64 \\
{[<.0001]}\end{array}$ \\
\hline 7 & $\begin{array}{c}0.87 \\
{[19.34]}\end{array}$ & $\begin{array}{c}1.13 \\
{[<.0001]}\end{array}$ & $\begin{array}{c}-0.02 \\
{[-0.29]}\end{array}$ & $\begin{array}{c}-0.01 \\
{[-0.15]}\end{array}$ & $\begin{array}{c}0.70 \\
{[5.71]}\end{array}$ & $\begin{array}{c}-0.72 \\
{[<.0001]}\end{array}$ \\
\hline 8 & $\begin{array}{c}0.93 \\
{[20.96]}\end{array}$ & $\begin{array}{c}1.13 \\
{[<.0001]}\end{array}$ & $\begin{array}{c}-0.05 \\
{[-0.85]}\end{array}$ & $\begin{array}{c}-0.01 \\
{[-0.11]}\end{array}$ & $\begin{array}{c}0.75 \\
{[6.16]}\end{array}$ & $\begin{array}{c}-0.70 \\
{[<.0001]}\end{array}$ \\
\hline 9 & $\begin{array}{c}0.91 \\
{[20.32]}\end{array}$ & $\begin{array}{c}1.21 \\
{[<.0001]}\end{array}$ & $\begin{array}{c}-0.08 \\
{[-1.48]}\end{array}$ & $\begin{array}{c}-0.06 \\
{[-0.99]}\end{array}$ & $\begin{array}{c}0.69 \\
{[5.31]}\end{array}$ & $\begin{array}{c}-0.85 \\
{[<.0001]}\end{array}$ \\
\hline 10 & $\begin{array}{c}0.83 \\
{[18.22]}\end{array}$ & $\begin{array}{c}1.08 \\
{[<.0001]}\end{array}$ & $\begin{array}{l}-0.16 \\
{[-2.68]}\end{array}$ & $\begin{array}{c}-0.13 \\
{[-2.18]}\end{array}$ & $\begin{array}{c}0.35 \\
{[2.73]}\end{array}$ & $\begin{array}{c}-1.15 \\
{[<.0001]}\end{array}$ \\
\hline $1-10$ & $\begin{array}{c}0.52 * * * \\
{[<.0001]}\end{array}$ & $\begin{array}{c}0.46 * * * \\
{[<.0001]}\end{array}$ & $\begin{array}{c}0.36 * * * \\
{[.0002]}\end{array}$ & $\begin{array}{l}0.24 * * * \\
{[.0139]}\end{array}$ & $\begin{array}{c}2.08^{* * *} \\
{[<.0001]}\end{array}$ & $\begin{array}{r}1.13^{* * *} \\
{[<.0001]}\end{array}$ \\
\hline
\end{tabular}




\begin{tabular}{|c|c|c|c|c|c|c|}
\hline \multirow{2}{*}{$\begin{array}{l}\text { Disposition } \\
\text { Deciles }\end{array}$} & \multicolumn{2}{|c|}{ Monthly Raw Return } & \multirow{2}{*}{$\begin{array}{c}\text { 3-factor } \\
\text { alpha }\end{array}$} & \multirow{2}{*}{$\begin{array}{c}\text { 4-factor } \\
\text { alpha }\end{array}$} & \multicolumn{2}{|c|}{ Fund flows } \\
\hline & mean & median & & & mean & median \\
\hline \multicolumn{7}{|c|}{ Panel B Formation period is 1 year } \\
\hline 1 & $\begin{array}{c}1.20 \\
{[55.46]}\end{array}$ & $\begin{array}{c}1.40 \\
{[<.0001]}\end{array}$ & $\begin{array}{c}0.11 \\
{[18.91]}\end{array}$ & $\begin{array}{c}0.06 \\
{[4.98]}\end{array}$ & $\begin{array}{c}2.81 \\
{[21.53]}\end{array}$ & $\begin{array}{c}0.17 \\
{[0.0149]}\end{array}$ \\
\hline 2 & $\begin{array}{c}1.09 \\
{[52.06]}\end{array}$ & $\begin{array}{c}1.34 \\
{[<.0001]}\end{array}$ & $\begin{array}{c}0.09 \\
{[9.13]}\end{array}$ & $\begin{array}{c}-0.01 \\
{[-0.86]}\end{array}$ & $\begin{array}{c}1.87 \\
{[15.02]}\end{array}$ & $\begin{array}{c}-0.31 \\
{[<.0001]}\end{array}$ \\
\hline 3 & $\begin{array}{c}1.03 \\
{[49.51]}\end{array}$ & $\begin{array}{c}1.29 \\
{[<.0001]}\end{array}$ & $\begin{array}{c}0.01 \\
{[0.67]}\end{array}$ & $\begin{array}{c}-0.06 \\
{[-5.92]}\end{array}$ & $\begin{array}{c}1.67 \\
{[13.47]}\end{array}$ & $\begin{array}{c}-0.36 \\
{[<.0001]}\end{array}$ \\
\hline 4 & $\begin{array}{c}1.00 \\
{[48.40]}\end{array}$ & $\begin{array}{c}1.27 \\
{[<.0001]}\end{array}$ & $\begin{array}{c}-0.02 \\
{[-2.06]}\end{array}$ & $\begin{array}{c}-0.07 \\
{[-6.26]}\end{array}$ & $\begin{array}{c}1.38 \\
{[11.85]}\end{array}$ & $\begin{array}{c}-0.49 \\
{[<.0001]}\end{array}$ \\
\hline 5 & $\begin{array}{c}1.00 \\
{[48.95]}\end{array}$ & $\begin{array}{c}1.25 \\
{[<.0001]}\end{array}$ & $\begin{array}{c}-0.03 \\
{[-2.91]}\end{array}$ & $\begin{array}{c}-0.07 \\
{[-6.38]}\end{array}$ & $\begin{array}{c}1.56 \\
{[12.77]}\end{array}$ & $\begin{array}{c}-0.41 \\
{[<.0001]}\end{array}$ \\
\hline 6 & $\begin{array}{c}0.97 \\
{[47.92]}\end{array}$ & $\begin{array}{c}1.23 \\
{[<.0001]}\end{array}$ & $\begin{array}{c}-0.09 \\
{[-8.27]}\end{array}$ & $\begin{array}{c}-0.09 \\
{[-8.24]}\end{array}$ & $\begin{array}{c}1.28 \\
{[10.53]}\end{array}$ & $\begin{array}{c}-0.59 \\
{[<.0001]}\end{array}$ \\
\hline 7 & $\begin{array}{c}0.93 \\
{[46.93]}\end{array}$ & $\begin{array}{c}1.20 \\
{[<.0001]}\end{array}$ & $\begin{array}{c}-0.13 \\
{[-11.42]}\end{array}$ & $\begin{array}{c}-0.10 \\
{[-8.42]}\end{array}$ & $\begin{array}{c}1.35 \\
{[10.94]}\end{array}$ & $\begin{array}{c}-0.57 \\
{[<.0001]}\end{array}$ \\
\hline 8 & $\begin{array}{c}0.87 \\
{[45.34]}\end{array}$ & $\begin{array}{c}1.17 \\
{[<.0001]}\end{array}$ & $\begin{array}{c}-0.21 \\
{[-18.72]}\end{array}$ & $\begin{array}{c}-0.13 \\
{[-12.24]}\end{array}$ & $\begin{array}{c}0.90 \\
{[7.48]}\end{array}$ & $\begin{array}{c}-0.86 \\
{[<.0001]}\end{array}$ \\
\hline 9 & $\begin{array}{c}0.90 \\
{[46.53]}\end{array}$ & $\begin{array}{c}1.18 \\
{[<.0001]}\end{array}$ & $\begin{array}{c}-0.21 \\
{[-19.57]}\end{array}$ & $\begin{array}{c}-0.11 \\
{[-10.25]}\end{array}$ & $\begin{array}{c}1.01 \\
{[8.38]}\end{array}$ & $\begin{array}{c}-0.72 \\
{[<.0001]}\end{array}$ \\
\hline 10 & $\begin{array}{c}0.80 \\
{[39.54]}\end{array}$ & $\begin{array}{c}1.07 \\
{[<.0001]}\end{array}$ & $\begin{array}{c}-0.25 \\
{[-25.14]}\end{array}$ & $\begin{array}{c}-0.15 \\
{[-11.71]}\end{array}$ & $\begin{array}{c}0.82 \\
{[6.33]}\end{array}$ & $\begin{array}{c}-0.93 \\
{[<.0001]}\end{array}$ \\
\hline $1-10$ & $\begin{array}{c}0.40 * * * \\
{[<.0001]}\end{array}$ & $\begin{array}{c}0.33 * * * \\
{[<.0001]}\end{array}$ & $\begin{array}{c}0.36 * * * \\
{[<.0001]}\end{array}$ & $\begin{array}{c}0.21^{* *} \\
{[0.0230]}\end{array}$ & $\begin{array}{c}1.99 * * * \\
{[<.0001]}\end{array}$ & $\begin{array}{l}1.10^{* * * *} \\
{[<.0001]}\end{array}$ \\
\hline
\end{tabular}




\section{Table 4.2: Disposition Effect and Fund Performance - Number-of-shares Weighted Disposition Spread}

This table reports the fund performance for each disposition spread decile, where the disposition spread are measured in terms of number of shares. Disposition spread deciles are constructed based on formation periods of one quarter and one year. Each quarter and within each investment category, funds are ranked into deciles based on their disposition spreads in the previous quarter or their average disposition spreads over the past four quarters. Funds in decile 10 have the highest disposition spread and funds in decile 1 have the lowest (or most negative) disposition spread. All returns are reported for the quarter immediately following the formation quarter(s). Monthly raw return for each decile portfolio is calculated by equally weighting monthly raw returns of the funds in that portfolio. The time-series means and medians of the portfolio monthly raw returns are reported in the second and third columns. Intercepts from 3-factor and 4-factor regression models are also reported as risk-adjsuted returns for each decile portfolio. Fund flows for the quarter immediately after the portfolio formation period are calculated as $F L_{i, t}=\frac{T N A_{i, t}-T N A_{i, t-1}\left(1+r_{i, t}\right)}{T N A_{i, t-1}}$, where $T N A_{i, t}$ is the total net assets of fund $i$ at the end of quarter $t$, and $r_{i, t}$ is the total return of fund $i$ in quarter $t$. Fund flows are equally weighted within each decile portfolio. T-statistics for means and p-values for medians and differences are reported in brackets. *, ${ }^{* *}$, and $* * *$ denote significance at $10 \%, 5 \%$ and $1 \%$ level, respectively. 


\begin{tabular}{|c|c|c|c|c|c|c|}
\hline \multirow{2}{*}{$\begin{array}{l}\text { Disposition } \\
\text { Deciles }\end{array}$} & \multicolumn{2}{|c|}{ Monthly Raw Return } & \multirow{2}{*}{$\begin{array}{l}\text { 3-factor } \\
\text { alpha }\end{array}$} & \multirow{2}{*}{$\begin{array}{l}\text { 4-factor } \\
\text { alpha }\end{array}$} & \multicolumn{2}{|c|}{ Fund flows } \\
\hline & mean & median & & & mean & median \\
\hline \multicolumn{7}{|c|}{ Panel A Formation period is 1 quarter } \\
\hline 1 & $\begin{array}{c}1.27 \\
{[25.64]}\end{array}$ & $\begin{array}{c}1.44 \\
{[<.0001]}\end{array}$ & $\begin{array}{c}0.16 \\
{[2.62]}\end{array}$ & $\begin{array}{c}0.09 \\
{[1.48]}\end{array}$ & $\begin{array}{c}2.42 \\
{[15.87]}\end{array}$ & $\begin{array}{c}-0.20 \\
{[0.0328]}\end{array}$ \\
\hline 2 & $\begin{array}{c}1.17 \\
{[24.04]}\end{array}$ & $\begin{array}{c}1.38 \\
{[<.0001]}\end{array}$ & $\begin{array}{c}0.08 \\
{[1.17]}\end{array}$ & $\begin{array}{c}-0.00 \\
{[-0.04]}\end{array}$ & $\begin{array}{c}1.72 \\
{[13.24]}\end{array}$ & $\begin{array}{c}-0.23 \\
{[0.0152]}\end{array}$ \\
\hline 3 & $\begin{array}{c}1.07 \\
{[22.43]}\end{array}$ & $\begin{array}{c}1.28 \\
{[<.0001]}\end{array}$ & $\begin{array}{c}-0.02 \\
{[-0.30]}\end{array}$ & $\begin{array}{c}-0.06 \\
{[-0.93]}\end{array}$ & $\begin{array}{c}1.41 \\
{[10.64]}\end{array}$ & $\begin{array}{c}-0.27 \\
{[0.0037]}\end{array}$ \\
\hline 4 & $\begin{array}{c}1.05 \\
{[22.67]}\end{array}$ & $\begin{array}{c}1.28 \\
{[<.0001]}\end{array}$ & $\begin{array}{c}0.04 \\
{[0.73]}\end{array}$ & $\begin{array}{c}0.02 \\
{[0.43]}\end{array}$ & $\begin{array}{c}1.17 \\
{[9.06]}\end{array}$ & $\begin{array}{c}-0.55 \\
{[<.0001]}\end{array}$ \\
\hline 5 & $\begin{array}{c}0.99 \\
{[21.79]}\end{array}$ & $\begin{array}{c}1.24 \\
{[<.0001]}\end{array}$ & $\begin{array}{c}-0.02 \\
{[-0.32]}\end{array}$ & $\begin{array}{c}-0.03 \\
{[-0.59]}\end{array}$ & $\begin{array}{c}1.05 \\
{[8.39]}\end{array}$ & $\begin{array}{c}-0.49 \\
{[<.0001]}\end{array}$ \\
\hline 6 & $\begin{array}{c}0.96 \\
{[21.07]}\end{array}$ & $\begin{array}{c}1.24 \\
{[<.0001]}\end{array}$ & $\begin{array}{c}-0.07 \\
{[-1.11]}\end{array}$ & $\begin{array}{c}-0.05 \\
{[-0.96]}\end{array}$ & $\begin{array}{c}1.15 \\
{[8.73]}\end{array}$ & $\begin{array}{c}-0.66 \\
{[<.0001]}\end{array}$ \\
\hline 7 & $\begin{array}{c}0.94 \\
{[21.22]}\end{array}$ & $\begin{array}{c}1.25 \\
{[<.0001]}\end{array}$ & $\begin{array}{c}-0.03 \\
{[-0.42]}\end{array}$ & $\begin{array}{c}-0.03 \\
{[-0.41]}\end{array}$ & $\begin{array}{c}0.81 \\
{[6.53]}\end{array}$ & $\begin{array}{c}-0.58 \\
{[<.0001]}\end{array}$ \\
\hline 8 & $\begin{array}{c}0.95 \\
{[21.44]}\end{array}$ & $\begin{array}{c}1.21 \\
{[<.0001]}\end{array}$ & $\begin{array}{c}-0.02 \\
{[-0.26]}\end{array}$ & $\begin{array}{c}0.04 \\
{[0.35]}\end{array}$ & $\begin{array}{c}0.74 \\
{[6.11]}\end{array}$ & $\begin{array}{c}-0.73 \\
{[<.0001]}\end{array}$ \\
\hline 9 & $\begin{array}{c}0.88 \\
{[19.58]}\end{array}$ & $\begin{array}{c}1.17 \\
{[<.0001]}\end{array}$ & $\begin{array}{c}-0.09 \\
{[-1.57]}\end{array}$ & $\begin{array}{c}-0.05 \\
{[-0.81]}\end{array}$ & $\begin{array}{c}0.51 \\
{[4.06]}\end{array}$ & $\begin{array}{c}-0.97 \\
{[<.0001]}\end{array}$ \\
\hline 10 & $\begin{array}{c}0.81 \\
{[17.84]}\end{array}$ & $\begin{array}{c}1.08 \\
{[<.0001]}\end{array}$ & $\begin{array}{l}-0.10 \\
{[-2.45]}\end{array}$ & $\begin{array}{c}-0.11 \\
{[-2.10]}\end{array}$ & $\begin{array}{c}-0.14 \\
{[-1.16]}\end{array}$ & $\begin{array}{c}-1.33 \\
{[<.0001]}\end{array}$ \\
\hline $1-10$ & $\begin{array}{c}0.46 * * * \\
{[<.0001]}\end{array}$ & $\begin{array}{c}0.36 * * * \\
{[<.0001]}\end{array}$ & $\begin{array}{c}0.26 * * * \\
{[.0008]}\end{array}$ & $\begin{array}{c}0.20 * * * \\
{[.0160]}\end{array}$ & $\begin{array}{c}2.56 * * * \\
{[<.0001]}\end{array}$ & $\begin{array}{r}1.13^{* * *} \\
{[<.0001]}\end{array}$ \\
\hline
\end{tabular}




\begin{tabular}{|c|c|c|c|c|c|c|}
\hline \multirow{2}{*}{$\begin{array}{l}\text { Disposition } \\
\text { Deciles }\end{array}$} & \multicolumn{2}{|c|}{ Monthly Raw Return } & \multirow{2}{*}{$\begin{array}{c}\text { 3-factor } \\
\text { alpha }\end{array}$} & \multirow{2}{*}{$\begin{array}{c}\text { 4-factor } \\
\text { alpha }\end{array}$} & \multicolumn{2}{|c|}{ Fund flows } \\
\hline & mean & median & & & mean & median \\
\hline \multicolumn{7}{|c|}{ Panel B Formation period is 1 year } \\
\hline 1 & $\begin{array}{c}1.18 \\
{[52.82]}\end{array}$ & $\begin{array}{c}1.36 \\
{[<.0001]}\end{array}$ & $\begin{array}{c}0.10 \\
{[18.41]}\end{array}$ & $\begin{array}{c}0.05 \\
{[3.97]}\end{array}$ & $\begin{array}{c}3.25 \\
{[22.83]}\end{array}$ & $\begin{array}{c}0.16 \\
{[0.0318]}\end{array}$ \\
\hline 2 & $\begin{array}{c}1.07 \\
{[49.89]}\end{array}$ & $\begin{array}{c}1.29 \\
{[<.0001]}\end{array}$ & $\begin{array}{c}0.09 \\
{[7.59]}\end{array}$ & $\begin{array}{c}-0.03 \\
{[-2.44]}\end{array}$ & $\begin{array}{c}2.14 \\
{[17.69]}\end{array}$ & $\begin{array}{c}-0.04 \\
{[0.6055]}\end{array}$ \\
\hline 3 & $\begin{array}{c}1.04 \\
{[49.93]}\end{array}$ & $\begin{array}{c}1.31 \\
{[<.0001]}\end{array}$ & $\begin{array}{c}0.03 \\
{[2.87]}\end{array}$ & $\begin{array}{c}-0.05 \\
{[-4.47]}\end{array}$ & $\begin{array}{c}1.81 \\
{[14.63]}\end{array}$ & $\begin{array}{c}-0.22 \\
{[0.0032]}\end{array}$ \\
\hline 4 & $\begin{array}{c}0.98 \\
{[47.58]}\end{array}$ & $\begin{array}{c}1.25 \\
{[<.0001]}\end{array}$ & $\begin{array}{c}-0.04 \\
{[-3.30]}\end{array}$ & $\begin{array}{c}-0.08 \\
{[-6.95]}\end{array}$ & $\begin{array}{c}1.55 \\
{[12.55]}\end{array}$ & $\begin{array}{c}-0.39 \\
{[<.0001]}\end{array}$ \\
\hline 5 & $\begin{array}{c}0.97 \\
{[48.25]}\end{array}$ & $\begin{array}{c}1.24 \\
{[<.0001]}\end{array}$ & $\begin{array}{c}-0.07 \\
{[-7.06]}\end{array}$ & $\begin{array}{c}-0.09 \\
{[-8.34]}\end{array}$ & $\begin{array}{c}1.56 \\
{[12.70]}\end{array}$ & $\begin{array}{c}-0.48 \\
{[<.0001]}\end{array}$ \\
\hline 6 & $\begin{array}{c}0.95 \\
{[47.96]}\end{array}$ & $\begin{array}{c}1.23 \\
{[<.0001]}\end{array}$ & $\begin{array}{c}-0.09 \\
{[-8.46]}\end{array}$ & $\begin{array}{c}-0.09 \\
{[-8.39]}\end{array}$ & $\begin{array}{c}1.35 \\
{[11.24]}\end{array}$ & $\begin{array}{c}-0.48 \\
{[<.0001]}\end{array}$ \\
\hline 7 & $\begin{array}{c}0.94 \\
{[47.61]}\end{array}$ & $\begin{array}{c}1.21 \\
{[<.0001]}\end{array}$ & $\begin{array}{c}-0.14 \\
{[-13.14]}\end{array}$ & $\begin{array}{c}-0.11 \\
{[-9.91]}\end{array}$ & $\begin{array}{c}1.08 \\
{[9.07]}\end{array}$ & $\begin{array}{c}-0.71 \\
{[<.0001]}\end{array}$ \\
\hline 8 & $\begin{array}{c}0.91 \\
{[47.03]}\end{array}$ & $\begin{array}{c}1.20 \\
{[<.0001]}\end{array}$ & $\begin{array}{c}-0.18 \\
{[-15.81]}\end{array}$ & $\begin{array}{c}-0.12 \\
{[-10.24]}\end{array}$ & $\begin{array}{c}0.93 \\
{[7.72]}\end{array}$ & $\begin{array}{c}-0.76 \\
{[<.0001]}\end{array}$ \\
\hline 9 & $\begin{array}{c}0.91 \\
{[47.66]}\end{array}$ & $\begin{array}{c}1.20 \\
{[<.0001]}\end{array}$ & $\begin{array}{c}-0.18 \\
{[-18.95]}\end{array}$ & $\begin{array}{c}-0.09 \\
{[-9.71]}\end{array}$ & $\begin{array}{c}0.82 \\
{[6.89]}\end{array}$ & $\begin{array}{c}-0.85 \\
{[<.0001]}\end{array}$ \\
\hline 10 & $\begin{array}{c}0.85 \\
{[42.52]}\end{array}$ & $\begin{array}{c}1.11 \\
{[<.0001]}\end{array}$ & $\begin{array}{c}-0.20 \\
{[-23.38]}\end{array}$ & $\begin{array}{c}-0.11 \\
{[-9.31]}\end{array}$ & $\begin{array}{c}0.22 \\
{[1.82]}\end{array}$ & $\begin{array}{c}-1.27 \\
{[<.0001]}\end{array}$ \\
\hline $1-10$ & $\begin{array}{c}0.33^{* * *} \\
{[<.0001]}\end{array}$ & $\begin{array}{c}0.25 * * * \\
{[<.0001]}\end{array}$ & $\begin{array}{c}0.30 * * * \\
{[<.0001]}\end{array}$ & $\begin{array}{c}0.16^{* *} \\
{[0.0230]}\end{array}$ & $\begin{array}{l}3.03 * * * \\
{[<.0001]}\end{array}$ & $\begin{array}{l}1.43^{* * *} \\
{[<.0001]}\end{array}$ \\
\hline
\end{tabular}




\section{Table 5.1: Disposition effect and Fund Performance Regression Results - Value-weighted Disposition Spread}

Regression results relating the disposition effect and fund performance are presented. Each quarter risk-adjusted fund returns are regressed on the disposition spread and control variables as Performance $_{i, t}=a_{i, t}+b_{1} \times$ Disp $_{i, t}+b_{2} \times$ LnTNA $_{i, t}+b_{3} \times \operatorname{Exp}_{i, t}$ The risk-adjusted fund returns are $+b_{4} \times$ Load $_{i, t}+b_{5} \times$ Turnover $_{i, t}+b_{6} \operatorname{Re}_{i, t}+\varepsilon_{i t}$

quarterly alphas computed by compounding the monthly alphas estimated for each month in a quarter. The monthly alphas are from 3-factor and 4-factor models using the returns in the prior 36 months. The disposition spreads are weighted by dollar value. The control variables are natural log of fund size as at quarter-end, expense ratio, maximum load, turnover, and the previous quarter's return. Time-series average coefficients from the Fama-MacBeth regressions and tstatistics (in parentheses) are reported. *, **, and *** denote significance at $10 \%, 5 \%$ and $1 \%$ level, respectively.

\begin{tabular}{lll}
\hline & 3 -factor alpha & 4 -factor alpha \\
\hline Intercept & -0.0045 & 0.0002 \\
& {$[-1.58]$} & {$[0.79]$} \\
Disposition spread & $-0.0142^{* * *}$ & $-0.0075^{* * *}$ \\
& {$[-5.81]$} & {$[-4.10]$} \\
Log of fund size & 0.0001 & -0.0002 \\
& {$[0.51]$} & {$[-0.66]$} \\
Expense ratio & $-0.3300^{* * *}$ & $-0.3785^{* * *}$ \\
& {$[-3.07]$} & {$[-3.03]$} \\
Maximum load & $-0.0002^{* * *}$ & $-0.0001^{* * *}$ \\
Turnover & {$[-2.19]$} & {$[-2.07]$} \\
& $0.0017^{* * *}$ & 0.0001 \\
Previous quarter's return & {$[2.19]$} & {$[0.10]$} \\
Adjusted $\mathrm{R}^{2}$ & $0.0627^{* * *}$ & $0.0610^{* * *}$ \\
\hline
\end{tabular}




\section{Table 5.2: Disposition effect and Fund Performance Regression Results - Number-of-shares Weighted Disposition Spread}

Regression results relating the disposition effect and fund performance are presented. Each quarter risk-adjusted fund returns are regressed on the disposition spread and control variables as Performance $_{i, t}=a_{i, t}+b_{1} \times$ Disp $_{i, t}+b_{2} \times$ LnTNA $_{i, t}+b_{3} \times \operatorname{Exp}_{i, t}$ The risk-adjusted fund returns are $+b_{4} \times$ Load $_{i, t}+b_{5} \times$ Turnover $_{i, t}+b_{6} \operatorname{Re}_{i, t}+\varepsilon_{i t}$

quarterly alphas computed by compounding the monthly alphas estimated for each month in a quarter. The monthly alphas are from 3-factor and 4-factor models using the returns in the prior 36 months. The disposition spreads are weighted by number of shares. The control variables are natural log of fund size as at quarter-end, expense ratio, maximum load, turnover, and the previous quarter's return. Time-series average coefficients from the Fama-MacBeth regressions and t-statistics (in parentheses) are reported. *, **, and *** denote significance at $10 \%, 5 \%$ and $1 \%$ level, respectively.

\begin{tabular}{lll}
\hline & 3 -factor alpha & 4-factor alpha \\
\hline Intercept & -0.0031 & 0.0010 \\
& {$[-1.13]$} & {$[0.35]$} \\
Disposition spread & $-0.0172^{* * *}$ & $-0.0092^{* * *}$ \\
& {$[-5.63]$} & {$[-4.41]$} \\
Log of fund size & 0.0002 & -0.0001 \\
& {$[0.66]$} & {$[-0.55]$} \\
Expense ratio & $-0.3310^{* * *}$ & $-0.3696 * * *$ \\
& {$[-3.19]$} & {$[-3.05]$} \\
Maximum load & $-0.0002^{* * *}$ & $-0.0001^{* * *}$ \\
Turnover & {$[-2.44]$} & {$[-2.20]$} \\
& $0.0017^{* * *}$ & 0.0001 \\
Previous quarter's return & {$[2.23]$} & {$[0.09]$} \\
Adjusted $\mathrm{R}^{2}$ & $0.0652^{* * *}$ & $0.0631^{* * *}$ \\
\hline
\end{tabular}




\section{Table 6.1: Characteristics of Portfolios by Performance and Disposition Spread - Value-weighted Disposition Spread}

This table summarizes characteristics of equally weighted portfolios based on fund performance and the disposition spread. Every quarter and within each investment category, funds are sorted into deciles based on their previous quarter's raw returns. Funds in the same performance decile are further sorted into quintiles based on their average disposition spreads over the same performance quarter. The disposition spreads are weighted by dollar value. Funds in the top quintile have the highest disposition spread (Disp), and funds in the bottom quintile have the lowest disposition spread (Nondisp). At the end of each portfolio formation period, portfolio characteristics are calculated by equally weighting all funds in the portfolio. The first number in each cell is the decile mean and the second number in each cell is the decile median.

\begin{tabular}{|c|c|c|c|c|c|c|}
\hline \multicolumn{2}{|r|}{ Portfolio } & \multirow{2}{*}{$\begin{array}{c}\begin{array}{c}\text { Disposition } \\
\text { Spread }\end{array} \\
-47.2 \%\end{array}$} & \multirow{2}{*}{$\begin{array}{c}\begin{array}{c}\text { Total Net } \\
\text { Assets }\end{array} \\
374\end{array}$} & \multirow{2}{*}{$\begin{array}{c}\begin{array}{c}\text { Expense } \\
\text { Ratio }\end{array} \\
1.37 \%\end{array}$} & \multirow{2}{*}{$\begin{array}{c}\text { Turnover } \\
96 \%\end{array}$} & \multirow{2}{*}{$\begin{array}{c}\begin{array}{c}\text { Past } 12- \\
\text { month return }\end{array} \\
5.7 \%\end{array}$} \\
\hline 1 & Nondisp & & & & & \\
\hline & & $-48.1 \%$ & 211 & $1.33 \%$ & $89 \%$ & $7.4 \%$ \\
\hline & Disp & $25.5 \%$ & 288 & $1.54 \%$ & $102 \%$ & $4.4 \%$ \\
\hline & & $24.5 \%$ & 153 & $1.42 \%$ & $91 \%$ & $7.6 \%$ \\
\hline \multirow[t]{4}{*}{2} & Nondisp & $-50.1 \%$ & 533 & $1.24 \%$ & $91 \%$ & $10.16 \%$ \\
\hline & & $-49.3 \%$ & 301 & $1.26 \%$ & $92 \%$ & $11.7 \%$ \\
\hline & Disp & $16.96 \%$ & 407 & $1.26 \%$ & $84 \%$ & $8.36 \%$ \\
\hline & & $15.4 \%$ & 231 & $1.27 \%$ & $76 \%$ & $8.5 \%$ \\
\hline \multirow[t]{4}{*}{3} & Nondisp & $-50.6 \%$ & 530 & $1.22 \%$ & $87 \%$ & $11.3 \%$ \\
\hline & & $-49.5 \%$ & 304 & $1.25 \%$ & $87 \%$ & $15.3 \%$ \\
\hline & Disp & $15.8 \%$ & 588 & $1.21 \%$ & $74 \%$ & $10.7 \%$ \\
\hline & & $14.8 \%$ & 370 & $1.25 \%$ & $70 \%$ & $11.9 \%$ \\
\hline \multirow[t]{4}{*}{4} & Nondisp & $-51.5 \%$ & 493 & $1.16 \%$ & $92 \%$ & $12.8 \%$ \\
\hline & & $-51.3 \%$ & 306 & $1.20 \%$ & $88 \%$ & $14.6 \%$ \\
\hline & Disp & $15.8 \%$ & 621 & $1.16 \%$ & $85 \%$ & $11.3 \%$ \\
\hline & & $13.7 \%$ & 328 & $1.16 \%$ & $79 \%$ & $13.1 \%$ \\
\hline \multirow[t]{4}{*}{5} & Nondisp & $-52.1 \%$ & 725 & $1.12 \%$ & $93 \%$ & $14.3 \%$ \\
\hline & & $-52.9 \%$ & 385 & $1.18 \%$ & $91 \%$ & $15.6 \%$ \\
\hline & Disp & $15.6 \%$ & 507 & $1.12 \%$ & $76 \%$ & $12.4 \%$ \\
\hline & & $13.8 \%$ & 315 & $1.18 \%$ & $66 \%$ & $13.1 \%$ \\
\hline \multirow[t]{4}{*}{6} & Nondisp & $-54.2 \%$ & 694 & $1.13 \%$ & $87 \%$ & $15.5 \%$ \\
\hline & & $-54.2 \%$ & 371 & $1.16 \%$ & $84 \%$ & $16.2 \%$ \\
\hline & Disp & $13.4 \%$ & 553 & $1.10 \%$ & $71 \%$ & $13.8 \%$ \\
\hline & & $11.3 \%$ & 327 & $1.13 \%$ & $68 \%$ & $14.0 \%$ \\
\hline \multirow[t]{2}{*}{7} & Nondisp & $-53.4 \%$ & 532 & $1.12 \%$ & $91 \%$ & $17.0 \%$ \\
\hline & & $-54.7 \%$ & 361 & $1.16 \%$ & $88 \%$ & $18.1 \%$ \\
\hline
\end{tabular}




\begin{tabular}{|c|c|c|c|c|c|c|}
\hline & Disp & $\begin{array}{l}13.5 \% \\
11.9 \%\end{array}$ & $\begin{array}{l}698 \\
396\end{array}$ & $\begin{array}{l}1.13 \% \\
1.15 \%\end{array}$ & $\begin{array}{l}73 \% \\
68 \%\end{array}$ & $\begin{array}{l}15.3 \% \\
15.5 \%\end{array}$ \\
\hline 8 & Nondisp & $\begin{array}{l}-54.0 \% \\
-54.1 \%\end{array}$ & $\begin{array}{l}821 \\
486\end{array}$ & $\begin{array}{l}1.12 \% \\
1.20 \%\end{array}$ & $\begin{array}{l}86 \% \\
85 \%\end{array}$ & $\begin{array}{l}18.4 \% \\
20.7 \%\end{array}$ \\
\hline & Disp & $\begin{array}{l}14.7 \% \\
13.1 \%\end{array}$ & $\begin{array}{l}510 \\
316\end{array}$ & $\begin{array}{l}1.20 \% \\
1.20 \%\end{array}$ & $\begin{array}{l}82 \% \\
74 \%\end{array}$ & $\begin{array}{l}17.1 \% \\
16.6 \%\end{array}$ \\
\hline 9 & Nondisp & $\begin{array}{l}-59.2 \% \\
-58.3 \%\end{array}$ & $\begin{array}{l}698 \\
378\end{array}$ & $\begin{array}{l}1.17 \% \\
1.19 \%\end{array}$ & $\begin{array}{l}90 \% \\
82 \%\end{array}$ & $\begin{array}{l}20.9 \% \\
23.0 \%\end{array}$ \\
\hline & Disp & $\begin{array}{l}13.8 \% \\
11.2 \%\end{array}$ & $\begin{array}{l}612 \\
300\end{array}$ & $\begin{array}{l}1.15 \% \\
1.20 \%\end{array}$ & $\begin{array}{l}78 \% \\
68 \%\end{array}$ & $\begin{array}{l}19.3 \% \\
18.5 \%\end{array}$ \\
\hline 10 & Nondisp & $\begin{array}{l}-59.8 \% \\
-61.7 \%\end{array}$ & $\begin{array}{l}500 \\
327\end{array}$ & $\begin{array}{l}1.28 \% \\
1.26 \%\end{array}$ & $\begin{array}{l}99 \% \\
99 \%\end{array}$ & $\begin{array}{l}26.1 \% \\
24.3 \%\end{array}$ \\
\hline & Disp & $\begin{array}{l}15.7 \% \\
14.6 \%\end{array}$ & $\begin{array}{l}527 \\
327\end{array}$ & $\begin{array}{l}1.26 \% \\
1.28 \%\end{array}$ & $\begin{array}{l}84 \% \\
77 \%\end{array}$ & $\begin{array}{l}30.0 \% \\
21.8 \%\end{array}$ \\
\hline
\end{tabular}




\section{Table 6.2: Characteristics of Portfolios by Performance and Disposition Spread - Number-of-shares Weighted Disposition Spread}

This table summarizes characteristics of equally weighted portfolios based on fund performance and the disposition spread. Every quarter and within each investment category, funds are sorted into deciles based on their previous quarter's raw returns. Funds in the same performance decile are further sorted into quintiles based on their average disposition spreads over the same performance quarter. The disposition spreads are weighted by number of shares. Funds in the top quintile have the highest disposition spread (Disp), and funds in the bottom quintile have the lowest disposition spread (Nondisp). At the end of each portfolio formation period, portfolio characteristics are calculated by equally weighting all funds in the portfolio. The first number in each cell is the decile mean and the second number in each cell is the decile median.

\begin{tabular}{|c|c|c|c|c|c|c|}
\hline & Portfolio & $\begin{array}{l}\text { Disposition } \\
\text { Spread }\end{array}$ & $\begin{array}{l}\text { Total Net } \\
\text { Assets }\end{array}$ & $\begin{array}{c}\text { Expense } \\
\text { Ratio }\end{array}$ & Turnover & $\begin{array}{c}\text { Past 12- } \\
\text { month return }\end{array}$ \\
\hline \multirow[t]{4}{*}{1} & \multirow[t]{2}{*}{ Nondisp } & $-29.6 \%$ & 373 & $1.44 \%$ & $99 \%$ & $4.1 \%$ \\
\hline & & & & & & \\
\hline & \multirow[t]{2}{*}{ Disp } & $29.5 \%$ & 273 & $1.53 \%$ & $92 \%$ & $3.8 \%$ \\
\hline & & $27.7 \%$ & 180 & $1.43 \%$ & $85 \%$ & $7.0 \%$ \\
\hline \multirow[t]{4}{*}{2} & \multirow[t]{2}{*}{ Nondisp } & $-31.9 \%$ & 502 & $1.31 \%$ & $94 \%$ & $9.2 \%$ \\
\hline & & $-30.3 \%$ & 227 & $1.29 \%$ & $93 \%$ & $10.9 \%$ \\
\hline & \multirow[t]{2}{*}{ Disp } & $22.1 \%$ & 447 & $1.19 \%$ & $72 \%$ & $8.3 \%$ \\
\hline & & $22.7 \%$ & 265 & $1.23 \%$ & $65 \%$ & $9.9 \%$ \\
\hline \multirow[t]{4}{*}{3} & \multirow[t]{2}{*}{ Nondisp } & $-31.8 \%$ & 560 & $1.20 \%$ & $90 \%$ & $10.5 \%$ \\
\hline & & $-30.6 \%$ & 301 & $1.23 \%$ & $88 \%$ & $13.0 \%$ \\
\hline & \multirow[t]{2}{*}{ Disp } & $22.5 \%$ & 562 & $1.15 \%$ & $72 \%$ & $10.9 \%$ \\
\hline & & $21.9 \%$ & 315 & $1.19 \%$ & $71 \%$ & $12.0 \%$ \\
\hline \multirow[t]{4}{*}{4} & \multirow[t]{2}{*}{ Nondisp } & $-31.9 \%$ & 683 & $1.09 \%$ & $83 \%$ & $11.6 \%$ \\
\hline & & $-30.7 \%$ & 363 & $1.18 \%$ & $90 \%$ & $14.9 \%$ \\
\hline & \multirow[t]{2}{*}{ Disp } & $22.0 \%$ & 581 & $1.16 \%$ & $85 \%$ & $11.3 \%$ \\
\hline & & $20.8 \%$ & 345 & $1.08 \%$ & $71 \%$ & $13.7 \%$ \\
\hline \multirow[t]{4}{*}{5} & \multirow[t]{2}{*}{ Nondisp } & $-32.1 \%$ & 565 & $1.17 \%$ & $90 \%$ & $13.5 \%$ \\
\hline & & $-31.9 \%$ & 346 & $1.22 \%$ & $91 \%$ & $16.3 \%$ \\
\hline & \multirow[t]{2}{*}{ Disp } & $22.9 \%$ & 561 & $1.11 \%$ & $75 \%$ & $12.7 \%$ \\
\hline & & $20.5 \%$ & 405 & $1.12 \%$ & $70 \%$ & $13.5 \%$ \\
\hline \multirow[t]{4}{*}{6} & \multirow[t]{2}{*}{ Nondisp } & $-33.4 \%$ & 775 & $1.18 \%$ & $92 \%$ & $15.1 \%$ \\
\hline & & $-33.0 \%$ & 371 & $1.19 \%$ & $91 \%$ & $16.1 \%$ \\
\hline & \multirow[t]{2}{*}{ Disp } & $21.1 \%$ & 683 & $1.06 \%$ & $73 \%$ & $14.2 \%$ \\
\hline & & $20.2 \%$ & 384 & $1.11 \%$ & $66 \%$ & $14.0 \%$ \\
\hline \multirow[t]{2}{*}{7} & \multirow[t]{2}{*}{ Nondisp } & $-33.1 \%$ & 526 & $1.16 \%$ & $92 \%$ & $16.6 \%$ \\
\hline & & $-33.0 \%$ & 297 & $1.19 \%$ & $83 \%$ & $18.0 \%$ \\
\hline
\end{tabular}




\begin{tabular}{|c|c|c|c|c|c|c|}
\hline & Disp & $\begin{array}{l}19.7 \% \\
19.6 \%\end{array}$ & $\begin{array}{l}717 \\
434\end{array}$ & $\begin{array}{l}1.05 \% \\
1.10 \%\end{array}$ & $\begin{array}{l}71 \% \\
66 \%\end{array}$ & $\begin{array}{l}15.5 \% \\
15.9 \%\end{array}$ \\
\hline 8 & Nondisp & $\begin{array}{l}-34.2 \% \\
-33.1 \%\end{array}$ & $\begin{array}{l}637 \\
404\end{array}$ & $\begin{array}{l}1.18 \% \\
1.20 \%\end{array}$ & $\begin{array}{l}85 \% \\
87 \%\end{array}$ & $\begin{array}{l}18.2 \% \\
20.1 \%\end{array}$ \\
\hline & Disp & $\begin{array}{l}21.2 \% \\
20.1 \%\end{array}$ & $\begin{array}{l}491 \\
381\end{array}$ & $\begin{array}{l}1.19 \% \\
1.20 \%\end{array}$ & $\begin{array}{l}79 \% \\
72 \%\end{array}$ & $\begin{array}{l}17.4 \% \\
17.3 \%\end{array}$ \\
\hline 9 & Nondisp & $\begin{array}{l}-37.4 \% \\
-35.5 \%\end{array}$ & $\begin{array}{l}590 \\
319\end{array}$ & $\begin{array}{l}1.25 \% \\
1.25 \%\end{array}$ & $\begin{array}{l}89 \% \\
84 \%\end{array}$ & $\begin{array}{l}20.8 \% \\
20.5 \%\end{array}$ \\
\hline & Disp & $\begin{array}{l}21.2 \% \\
19.3 \%\end{array}$ & $\begin{array}{l}681 \\
354\end{array}$ & $\begin{array}{l}1.13 \% \\
1.17 \%\end{array}$ & $\begin{array}{l}75 \% \\
66 \%\end{array}$ & $\begin{array}{l}18.7 \% \\
17.7 \%\end{array}$ \\
\hline 10 & Nondisp & $\begin{array}{l}-40.1 \% \\
-38.0 \%\end{array}$ & $\begin{array}{l}479 \\
299\end{array}$ & $\begin{array}{l}1.32 \% \\
1.34 \%\end{array}$ & $\begin{array}{c}104 \% \\
99 \%\end{array}$ & $\begin{array}{l}26.8 \% \\
23.9 \%\end{array}$ \\
\hline & Disp & $\begin{array}{l}23.7 \% \\
23.7 \%\end{array}$ & $\begin{array}{l}490 \\
283\end{array}$ & $\begin{array}{l}1.25 \% \\
1.27 \%\end{array}$ & $\begin{array}{l}78 \% \\
73 \%\end{array}$ & $\begin{array}{l}22.6 \% \\
20.8 \%\end{array}$ \\
\hline
\end{tabular}




\section{Table 7.1: Disposition Effect and Fund Flows - Value-weighted Disposition Spread}

This table compares the level of fund flows between funds exhibiting strong disposition effects and funds without such behavior. Every quarter and within each investment category, funds are first sorted into deciles based on their returns in the previous quarter. Funds in the same performance decile are further sorted into quintiles based on their average disposition spreads over the performance measurement period. The disposition spreads are measured in terms of dollar value. Funds in the top quintile have the highest disposition spread (Disp), and funds in the bottom quintile have the lowest disposition spread (Nondisp). In the quarter immediately after the portfolio formation period, portfolio flows are calculated by equally weighting flows to the funds included in the portfolio. Fund flow is calculated as $F L_{i, t}=\frac{T N A_{i, t}-T N A_{i, t-1}\left(1+r_{i, t}\right)}{T N A_{i, t-1}}$, where $T N A_{i, t}$ is the total net assets of fund $i$ at the end of quarter $t$, and $r_{i, t}$ is the total return of fund $i$ in quarter $t$. The time-series means and medians of the portfolio flows are reported in Panel B. We also compare fund flows on an aggregate level. Funds in the bottom 2 return deciles are grouped into Low performance group (Low), funds in the middle 6 deciles are grouped into Medium performance group (Med), and funds in the top 2 deciles are grouped into High performance group (High). Within each return group, funds with the highest disposition spread (Disp) and lowest disposition spread (Nondisp) are further grouped into portfolios. Portfolio flows are calculated by equally weighting fund flows. The time-series means and medians of portfolio flows by return groups are reported in Panel A. The portfolio analysis is performed over the whole sample period of 1980-2004, and also for three sub-sample periods divided based on the capital gains tax rate changes. T-statistics for means and p-values for medians are reported in brackets. 


\begin{tabular}{|c|c|c|c|c|c|c|c|c|c|}
\hline \multirow[t]{2}{*}{ Return } & \multirow{2}{*}{$\begin{array}{l}\text { Disposition } \\
\text { Effect }\end{array}$} & \multicolumn{2}{|c|}{$1980-2004$} & \multicolumn{2}{|c|}{ 1980-86 } & \multicolumn{2}{|c|}{$1987-97$} & \multicolumn{2}{|c|}{ 1998-2004 } \\
\hline & & Mean & Median & Mean & Median & Mean & Median & Mean & Median \\
\hline \multicolumn{10}{|c|}{ Panel A: Return Group } \\
\hline \multirow[t]{3}{*}{ Low } & Nondisp & $\begin{array}{c}-0.18 \\
{[-0.74]}\end{array}$ & $\begin{array}{c}-1.69 \\
{[<.0001]}\end{array}$ & $\begin{array}{c}2.16 \\
{[2.51]}\end{array}$ & $\begin{array}{c}-0.70 \\
{[0.2792]}\end{array}$ & $\begin{array}{c}1.52 \\
{[3.34]}\end{array}$ & $\begin{array}{c}-1.81 \\
{[0.0012]}\end{array}$ & $\begin{array}{c}-2.34 \\
{[-6.56]}\end{array}$ & $\begin{array}{c}-2.15 \\
{[<.0001]}\end{array}$ \\
\hline & Disp & $\begin{array}{c}-1.31 \\
{[-5.93]}\end{array}$ & $\begin{array}{c}-2.18 \\
{[<.0001]}\end{array}$ & $\begin{array}{c}-1.28 \\
{[-2.20]}\end{array}$ & $\begin{array}{c}-2.09 \\
{[<.0001]}\end{array}$ & $\begin{array}{c}0.33 \\
{[0.81]}\end{array}$ & $\begin{array}{c}-1.52 \\
{[<.0001]}\end{array}$ & $\begin{array}{c}-2.56 \\
{[-9.62]}\end{array}$ & $\begin{array}{c}-2.71 \\
{[<.0001]}\end{array}$ \\
\hline & Difference & $\begin{array}{c}1.13 \\
{[3.43]}\end{array}$ & $\begin{array}{c}0.49 \\
{[<.0001]}\end{array}$ & $\begin{array}{c}3.43 \\
{[3.31]}\end{array}$ & $\begin{array}{c}1.39 \\
{[0.0004]}\end{array}$ & $\begin{array}{c}1.19 \\
{[1.95]}\end{array}$ & $\begin{array}{c}-0.29 \\
{[0.0038]}\end{array}$ & $\begin{array}{c}0.22 \\
{[0.84]}\end{array}$ & $\begin{array}{c}0.56 \\
{[0.0207]}\end{array}$ \\
\hline \multirow[t]{3}{*}{ Med } & Nondisp & $\begin{array}{c}1.96 \\
{[12.88]}\end{array}$ & $\begin{array}{c}-0.47 \\
{[<.0001]}\end{array}$ & $\begin{array}{c}2.22 \\
{[4.51]}\end{array}$ & $\begin{array}{c}-0.21 \\
{[0.5716]}\end{array}$ & $\begin{array}{c}3.86 \\
{[13.76]}\end{array}$ & $\begin{array}{c}0.47 \\
{[0.0013]}\end{array}$ & $\begin{array}{c}0.44 \\
{[2.51]}\end{array}$ & $\begin{array}{c}-1.01 \\
{[<.0001]}\end{array}$ \\
\hline & Disp & $\begin{array}{c}1.19 \\
{[8.20]}\end{array}$ & $\begin{array}{c}-0.86 \\
{[<.0001]}\end{array}$ & $\begin{array}{c}-0.00 \\
{[-0.00]}\end{array}$ & $\begin{array}{c}-1.33 \\
{[<.0001]}\end{array}$ & $\begin{array}{c}2.64 \\
{[9.96]}\end{array}$ & $\begin{array}{c}-0.36 \\
{[0.0032]}\end{array}$ & $\begin{array}{c}0.23 \\
{[1.29]}\end{array}$ & $\begin{array}{c}-1.18 \\
{[<.0001]}\end{array}$ \\
\hline & Difference & $\begin{array}{c}0.77 \\
{[3.66]}\end{array}$ & $\begin{array}{c}0.39 \\
{[<.0001]}\end{array}$ & $\begin{array}{c}2.22 \\
{[3.73]}\end{array}$ & $\begin{array}{c}1.12 \\
{[0.0004]}\end{array}$ & $\begin{array}{c}1.22 \\
{[3.17]}\end{array}$ & $\begin{array}{c}0.83 \\
{[<.0001]}\end{array}$ & $\begin{array}{c}0.21 \\
{[0.84]}\end{array}$ & $\begin{array}{c}0.17 \\
{[0.0739]}\end{array}$ \\
\hline \multirow[t]{3}{*}{ High } & Nondisp & $\begin{array}{c}6.86 \\
{[17.28]}\end{array}$ & $\begin{array}{c}2.01 \\
{[<.0001]}\end{array}$ & $\begin{array}{c}3.68 \\
{[3.33]}\end{array}$ & $\begin{array}{c}0.67 \\
{[0.4264]}\end{array}$ & $\begin{array}{c}9.71 \\
{[13.03]}\end{array}$ & $\begin{array}{c}3.33 \\
{[<.0001]}\end{array}$ & $\begin{array}{c}5.06 \\
{[11.22]}\end{array}$ & $\begin{array}{c}1.38 \\
{[<.0001]}\end{array}$ \\
\hline & Disp & $\begin{array}{c}4.53 \\
{[14.00]}\end{array}$ & $\begin{array}{c}0.77 \\
{[0.0000]}\end{array}$ & $\begin{array}{c}3.26 \\
{[3.16]}\end{array}$ & $\begin{array}{c}0.06 \\
{[0.9296]}\end{array}$ & $\begin{array}{c}6.32 \\
{[11.50]}\end{array}$ & $\begin{array}{c}1.77 \\
{[<.0001]}\end{array}$ & $\begin{array}{c}3.29 \\
{[7.84]}\end{array}$ & $\begin{array}{c}0.09 \\
{[0.6065]}\end{array}$ \\
\hline & Difference & $\begin{array}{c}2.33 \\
{[4.55]}\end{array}$ & $\begin{array}{c}1.24 \\
{[<.0001]}\end{array}$ & $\begin{array}{c}0.42 \\
{[0.27]}\end{array}$ & $\begin{array}{c}0.61 \\
{[0.3599]}\end{array}$ & $\begin{array}{c}3.39 \\
{[3.67]}\end{array}$ & $\begin{array}{c}1.56 \\
{[0.0027]}\end{array}$ & $\begin{array}{c}1.76 \\
{[2.86]}\end{array}$ & $\begin{array}{c}1.29 \\
{[0.0008]}\end{array}$ \\
\hline
\end{tabular}




\begin{tabular}{|c|c|c|c|c|c|c|c|c|c|}
\hline \multirow[t]{2}{*}{ Return } & \multirow{2}{*}{$\begin{array}{l}\text { Disposition } \\
\text { Effect }\end{array}$} & \multicolumn{2}{|c|}{$1980-2004$} & \multicolumn{2}{|c|}{$1980-86$} & \multicolumn{2}{|c|}{$1987-97$} & \multicolumn{2}{|c|}{$1998-2004$} \\
\hline & & Mean & Median & Mean & Median & Mean & Median & Mean & Median \\
\hline \multicolumn{10}{|c|}{ Panel B: Return Deciles } \\
\hline \multirow[t]{3}{*}{1} & Nondisp & $\begin{array}{c}-0.78 \\
{[-2.45]}\end{array}$ & $\begin{array}{c}-2.03 \\
{[<.0001]}\end{array}$ & $\begin{array}{c}1.82 \\
{[1.43]}\end{array}$ & $\begin{array}{c}-0.93 \\
{[0.5190]}\end{array}$ & $\begin{array}{c}0.72 \\
{[1.41]}\end{array}$ & $\begin{array}{c}-1.18 \\
{[0.0115]}\end{array}$ & $\begin{array}{c}-2.28 \\
{[-5.63]}\end{array}$ & $\begin{array}{c}-2.65 \\
{[<.0001]}\end{array}$ \\
\hline & Disp & $\begin{array}{c}-2.15 \\
{[-7.02]}\end{array}$ & $\begin{array}{c}-2.57 \\
{[<.0001]}\end{array}$ & $\begin{array}{c}-1.82 \\
{[-2.82]}\end{array}$ & $\begin{array}{c}-2.39 \\
{[0.0000]}\end{array}$ & $\begin{array}{c}-0.87 \\
{[-1.64]}\end{array}$ & $\begin{array}{c}-2.14 \\
{[<.0001]}\end{array}$ & $\begin{array}{c}-3.16 \\
{[-7.79]}\end{array}$ & $\begin{array}{c}-3.08 \\
{[<.0001]}\end{array}$ \\
\hline & Difference & $\begin{array}{c}1.37 \\
{[3.11]}\end{array}$ & $\begin{array}{c}0.54 \\
{[0.0003]}\end{array}$ & $\begin{array}{c}3.64 \\
{[2.54]}\end{array}$ & $\begin{array}{c}1.46 \\
{[0.0105]}\end{array}$ & $\begin{array}{c}1.59 \\
{[2.16]}\end{array}$ & $\begin{array}{c}0.96 \\
{[0.0020]}\end{array}$ & $\begin{array}{c}0.88 \\
{[1.52]}\end{array}$ & $\begin{array}{c}1.43 \\
{[0.0557]}\end{array}$ \\
\hline \multirow[t]{3}{*}{2} & Nondisp & $\begin{array}{c}0.39 \\
{[1.06]}\end{array}$ & $\begin{array}{c}-1.28 \\
{[<.0001]}\end{array}$ & $\begin{array}{c}2.47 \\
{[2.12]}\end{array}$ & $\begin{array}{c}-0.66 \\
{[0.4500]}\end{array}$ & $\begin{array}{c}2.29 \\
{[3.08]}\end{array}$ & $\begin{array}{c}-0.84 \\
{[0.0470]}\end{array}$ & $\begin{array}{c}-1.34 \\
{[-3.61]}\end{array}$ & $\begin{array}{c}-2.05 \\
{[<.0001]}\end{array}$ \\
\hline & Disp & $\begin{array}{c}-0.51 \\
{[-1.61]}\end{array}$ & $\begin{array}{c}-1.81 \\
{[<.0001]}\end{array}$ & $\begin{array}{c}-0.76 \\
{[-0.80]}\end{array}$ & $\begin{array}{c}-1.99 \\
{[0.0003]}\end{array}$ & $\begin{array}{c}1.49 \\
{[2.43]}\end{array}$ & $\begin{array}{c}-1.00 \\
{[0.0013]}\end{array}$ & $\begin{array}{c}-1.99 \\
{[-5.75]}\end{array}$ & $\begin{array}{c}-2.45 \\
{[<.0001]}\end{array}$ \\
\hline & Difference & $\begin{array}{c}0.90 \\
{[1.85]}\end{array}$ & $\begin{array}{c}0.53 \\
{[0.0163]}\end{array}$ & $\begin{array}{c}3.23 \\
{[2.15]}\end{array}$ & $\begin{array}{c}1.33 \\
{[0.0090]}\end{array}$ & $\begin{array}{c}0.80 \\
{[0.83]}\end{array}$ & $\begin{array}{c}0.16 \\
{[0.2046]}\end{array}$ & $\begin{array}{c}0.65 \\
{[1.27]}\end{array}$ & $\begin{array}{c}0.40 \\
{[0.0895]}\end{array}$ \\
\hline \multirow[t]{3}{*}{3} & Nondisp & $\begin{array}{c}0.87 \\
{[2.34]}\end{array}$ & $\begin{array}{c}-1.19 \\
{[<.0001]}\end{array}$ & $\begin{array}{c}3.65 \\
{[2.24]}\end{array}$ & $\begin{array}{c}-1.66 \\
{[0.3057]}\end{array}$ & $\begin{array}{c}2.90 \\
{[4.00]}\end{array}$ & $\begin{array}{c}-0.29 \\
{[0.6235]}\end{array}$ & $\begin{array}{c}-1.04 \\
{[-2.84]}\end{array}$ & $\begin{array}{c}-1.68 \\
{[<.0001]}\end{array}$ \\
\hline & Disp & $\begin{array}{c}0.39 \\
{[1.08]}\end{array}$ & $\begin{array}{c}-1.26 \\
{[<.0001]}\end{array}$ & $\begin{array}{c}-1.04 \\
{[-1.71]}\end{array}$ & $\begin{array}{c}-1.78 \\
{[0.0099]}\end{array}$ & $\begin{array}{c}2.36 \\
{[3.46]}\end{array}$ & $\begin{array}{c}-0.45 \\
{[0.1725]}\end{array}$ & $\begin{array}{c}-0.90 \\
{[-2.11]}\end{array}$ & $\begin{array}{c}-2.05 \\
{[<.0001]}\end{array}$ \\
\hline & Difference & $\begin{array}{c}0.48 \\
{[0.93]}\end{array}$ & $\begin{array}{c}0.07 \\
{[0.1198]}\end{array}$ & $\begin{array}{c}4.69 \\
{[2.70]}\end{array}$ & $\begin{array}{c}0.12 \\
{[0.0586]}\end{array}$ & $\begin{array}{c}0.54 \\
{[0.54]}\end{array}$ & $\begin{array}{c}0.16 \\
{[0.2590]}\end{array}$ & $\begin{array}{c}-0.14 \\
{[-0.25]}\end{array}$ & $\begin{array}{c}0.37 \\
{[0.2884]}\end{array}$ \\
\hline
\end{tabular}




\begin{tabular}{|c|c|c|c|c|c|c|c|c|c|}
\hline \multirow[t]{3}{*}{4} & Nondisp & $\begin{array}{c}0.91 \\
{[2.71]}\end{array}$ & $\begin{array}{c}-1.05 \\
{[<.0001]}\end{array}$ & $\begin{array}{c}1.51 \\
{[1.63]}\end{array}$ & $\begin{array}{c}0.35 \\
{[0.5386]}\end{array}$ & $\begin{array}{c}3.17 \\
{[4.95]}\end{array}$ & $\begin{array}{c}-0.00 \\
{[1.0000]}\end{array}$ & $\begin{array}{c}-0.93 \\
{[-2.51]}\end{array}$ & $\begin{array}{c}-1.76 \\
{[<.0001]}\end{array}$ \\
\hline & Disp & $\begin{array}{c}0.41 \\
{[1.16]}\end{array}$ & $\begin{array}{c}-1.38 \\
{[<.0001]}\end{array}$ & $\begin{array}{c}-0.31 \\
{[-0.41]}\end{array}$ & $\begin{array}{c}-1.72 \\
{[0.0019]}\end{array}$ & $\begin{array}{c}1.62 \\
{[2.42]}\end{array}$ & $\begin{array}{c}-0.89 \\
{[0.0121]}\end{array}$ & $\begin{array}{c}-0.41 \\
{[-0.98]}\end{array}$ & $\begin{array}{c}-1.81 \\
{[<.0001]}\end{array}$ \\
\hline & Difference & $\begin{array}{c}0.50 \\
{[1.02]}\end{array}$ & $\begin{array}{c}0.33 \\
{[0.0245]}\end{array}$ & $\begin{array}{c}1.83 \\
{[1.52]}\end{array}$ & $\begin{array}{c}2.07 \\
{[0.0208]}\end{array}$ & $\begin{array}{c}1.55 \\
{[1.67]}\end{array}$ & $\begin{array}{c}0.89 \\
{[0.0031]}\end{array}$ & $\begin{array}{c}-0.52 \\
{[-0.91]}\end{array}$ & $\begin{array}{c}0.05 \\
{[0.3136]}\end{array}$ \\
\hline \multirow[t]{3}{*}{5} & Nondisp & $\begin{array}{c}1.42 \\
{[4.36]}\end{array}$ & $\begin{array}{c}-0.38 \\
{[0.0209]}\end{array}$ & $\begin{array}{c}1.22 \\
{[1.39]}\end{array}$ & $\begin{array}{c}-0.61 \\
{[0.2145]}\end{array}$ & $\begin{array}{c}2.64 \\
{[5.16]}\end{array}$ & $\begin{array}{c}0.30 \\
{[0.2816]}\end{array}$ & $\begin{array}{c}0.48 \\
{[1.03]}\end{array}$ & $\begin{array}{c}-1.19 \\
{[0.0002]}\end{array}$ \\
\hline & Disp & $\begin{array}{c}0.90 \\
{[2.73]}\end{array}$ & $\begin{array}{c}-0.73 \\
{[<.0001]}\end{array}$ & $\begin{array}{c}-0.48 \\
{[-0.68]}\end{array}$ & $\begin{array}{c}-1.25 \\
{[0.0248]}\end{array}$ & $\begin{array}{c}2.44 \\
{[4.28]}\end{array}$ & $\begin{array}{c}-0.32 \\
{[0.3325]}\end{array}$ & $\begin{array}{c}-0.11 \\
{[-0.25]}\end{array}$ & $\begin{array}{c}-1.21 \\
{[<.0001]}\end{array}$ \\
\hline & Difference & $\begin{array}{c}0.52 \\
{[1.11]}\end{array}$ & $\begin{array}{c}0.35 \\
{[0.0766]}\end{array}$ & $\begin{array}{c}1.69 \\
{[1.51]}\end{array}$ & $\begin{array}{c}0.64 \\
{[0.1086]}\end{array}$ & $\begin{array}{c}0.20 \\
{[0.27]}\end{array}$ & $\begin{array}{c}0.62 \\
{[0.1180]}\end{array}$ & $\begin{array}{c}0.59 \\
{[0.93]}\end{array}$ & $\begin{array}{c}0.02 \\
{[0.2979]}\end{array}$ \\
\hline \multirow[t]{3}{*}{6} & Nondisp & $\begin{array}{c}2.36 \\
{[6.04]}\end{array}$ & $\begin{array}{c}-0.21 \\
{[0.2359]}\end{array}$ & $\begin{array}{c}2.64 \\
{[2.02]}\end{array}$ & $\begin{array}{c}0.16 \\
{[0.6089]}\end{array}$ & $\begin{array}{c}4.63 \\
{[6.41]}\end{array}$ & $\begin{array}{c}0.93 \\
{[0.0477]}\end{array}$ & $\begin{array}{c}0.57 \\
{[1.28]}\end{array}$ & $\begin{array}{c}-0.86 \\
{[0.0002]}\end{array}$ \\
\hline & Disp & $\begin{array}{c}1.03 \\
{[3.18]}\end{array}$ & $\begin{array}{c}-0.82 \\
{[<.0001]}\end{array}$ & $\begin{array}{c}-0.39 \\
{[-0.62]}\end{array}$ & $\begin{array}{c}-1.62 \\
{[0.0099]}\end{array}$ & $\begin{array}{c}2.47 \\
{[4.18]}\end{array}$ & $\begin{array}{c}-0.29 \\
{[0.2716]}\end{array}$ & $\begin{array}{c}0.12 \\
{[0.29]}\end{array}$ & $\begin{array}{c}-1.05 \\
{[0.0000]}\end{array}$ \\
\hline & Difference & $\begin{array}{c}1.33 \\
{[2.63]}\end{array}$ & $\begin{array}{c}0.61 \\
{[0.0049]}\end{array}$ & $\begin{array}{c}3.04 \\
{[2.09]}\end{array}$ & $\begin{array}{c}1.78 \\
{[0.0235]}\end{array}$ & $\begin{array}{c}2.16 \\
{[2.31]}\end{array}$ & $\begin{array}{c}1.22 \\
{[0.0039]}\end{array}$ & $\begin{array}{c}0.45 \\
{[0.76]}\end{array}$ & $\begin{array}{c}0.19 \\
{[0.2557]}\end{array}$ \\
\hline \multirow[t]{3}{*}{7} & Nondisp & $\begin{array}{c}2.27 \\
{[6.79]}\end{array}$ & $\begin{array}{c}-0.20 \\
{[0.3193]}\end{array}$ & $\begin{array}{c}1.42 \\
{[1.57]}\end{array}$ & $\begin{array}{c}-0.40 \\
{[0.7982]}\end{array}$ & $\begin{array}{c}3.59 \\
{[6.09]}\end{array}$ & $\begin{array}{c}0.67 \\
{[0.1327]}\end{array}$ & $\begin{array}{c}1.34 \\
{[3.18]}\end{array}$ & $\begin{array}{c}-0.60 \\
{[0.0087]}\end{array}$ \\
\hline & Disp & $\begin{array}{c}1.45 \\
{[4.38]}\end{array}$ & $\begin{array}{c}-0.77 \\
{[0.0014]}\end{array}$ & $\begin{array}{c}0.10 \\
{[0.13]}\end{array}$ & $\begin{array}{c}-1.29 \\
{[0.0396]}\end{array}$ & $\begin{array}{c}2.10 \\
{[3.83]}\end{array}$ & $\begin{array}{c}-0.41 \\
{[0.1975]}\end{array}$ & $\begin{array}{c}1.13 \\
{[2.47]}\end{array}$ & $\begin{array}{c}-0.80 \\
{[0.0149]}\end{array}$ \\
\hline & Difference & $\begin{array}{c}0.82 \\
{[1.73]}\end{array}$ & $\begin{array}{c}0.57 \\
{[0.0159]}\end{array}$ & $\begin{array}{c}1.31 \\
{[1.09]}\end{array}$ & $\begin{array}{c}0.89 \\
{[0.1505]}\end{array}$ & $\begin{array}{c}1.49 \\
{[1.85]}\end{array}$ & $\begin{array}{c}1.08 \\
{[0.0118]}\end{array}$ & $\begin{array}{c}0.21 \\
{[0.34]}\end{array}$ & $\begin{array}{c}0.20 \\
{[0.2349]}\end{array}$ \\
\hline
\end{tabular}




\begin{tabular}{|c|c|c|c|c|c|c|c|c|c|}
\hline \multirow[t]{3}{*}{8} & Nondisp & $\begin{array}{c}3.91 \\
{[8.67]}\end{array}$ & $\begin{array}{c}0.47 \\
{[0.0162]}\end{array}$ & $\begin{array}{c}2.94 \\
{[2.05]}\end{array}$ & $\begin{array}{c}-0.02 \\
{[1.0000]}\end{array}$ & $\begin{array}{c}6.25 \\
{[7.18]}\end{array}$ & $\begin{array}{c}1.22 \\
{[0.0002]}\end{array}$ & $\begin{array}{c}2.22 \\
{[4.59]}\end{array}$ & $\begin{array}{c}0.00 \\
{[1.0000]}\end{array}$ \\
\hline & Disp & $\begin{array}{c}2.92 \\
[7.06]]\end{array}$ & $\begin{array}{c}-0.05 \\
{[0.6805]}\end{array}$ & $\begin{array}{c}2.07 \\
{[1.72]}\end{array}$ & $\begin{array}{c}-0.58 \\
{[0.5323]}\end{array}$ & $\begin{array}{c}4.83 \\
{[6.09]}\end{array}$ & $\begin{array}{c}0.16 \\
{[0.8715]}\end{array}$ & $\begin{array}{c}1.56 \\
{[3.37]}\end{array}$ & $\begin{array}{c}-0.09 \\
{[0.6340]}\end{array}$ \\
\hline & Difference & $\begin{array}{c}0.99 \\
{[1.61]}\end{array}$ & $\begin{array}{c}0.52 \\
{[0.0088]}\end{array}$ & $\begin{array}{c}0.87 \\
{[0.46]}\end{array}$ & $\begin{array}{c}0.56 \\
{[0.2455]}\end{array}$ & $\begin{array}{l}1.42 \\
1.21]\end{array}$ & $\begin{array}{c}1.06 \\
{[0.0468]}\end{array}$ & $\begin{array}{c}0.66 \\
{[0.99]}\end{array}$ & $\begin{array}{c}0.09 \\
{[0.0602]}\end{array}$ \\
\hline \multirow[t]{3}{*}{9} & Nondisp & $\begin{array}{c}4.97 \\
{[9.99]}\end{array}$ & $\begin{array}{c}1.36 \\
{[<.0001]}\end{array}$ & $\begin{array}{c}1.97 \\
{[1.60]}\end{array}$ & $\begin{array}{c}-1.39 \\
{[0.2529]}\end{array}$ & $\begin{array}{c}7.72 \\
{[8.44]}\end{array}$ & $\begin{array}{c}2.75 \\
{[<.0001]}\end{array}$ & $\begin{array}{c}3.16 \\
{[5.43]}\end{array}$ & $\begin{array}{c}0.56 \\
{[0.0401]}\end{array}$ \\
\hline & Disp & $\begin{array}{c}3.79 \\
{[9.15]}\end{array}$ & $\begin{array}{c}0.30 \\
{[0.1637]}\end{array}$ & $\begin{array}{c}4.00 \\
{[2.82]}\end{array}$ & $\begin{array}{c}0.07 \\
{[0.8991]}\end{array}$ & $\begin{array}{c}5.34 \\
{[8.22]}\end{array}$ & $\begin{array}{c}1.61 \\
{[0.0014]}\end{array}$ & $\begin{array}{c}2.48 \\
{[4.33]}\end{array}$ & $\begin{array}{c}-0.21 \\
{[0.3285]}\end{array}$ \\
\hline & Difference & $\begin{array}{c}1.18 \\
{[1.83]}\end{array}$ & $\begin{array}{c}1.06 \\
{[0.0431]}\end{array}$ & $\begin{array}{l}-2.03 \\
{[-1.08]}\end{array}$ & $\begin{array}{c}-1.46 \\
{[0.0604]}\end{array}$ & $\begin{array}{c}2.38 \\
{[2.12]}\end{array}$ & $\begin{array}{c}1.14 \\
{[0.0388]}\end{array}$ & $\begin{array}{c}0.68 \\
{[0.82]}\end{array}$ & $\begin{array}{c}0.77 \\
{[0.0680]}\end{array}$ \\
\hline \multirow[t]{3}{*}{10} & Nondisp & $\begin{array}{c}8.73 \\
{[14.29]}\end{array}$ & $\begin{array}{c}3.18 \\
{[<.0001]}\end{array}$ & $\begin{array}{c}5.28 \\
{[2.94]}\end{array}$ & $\begin{array}{c}1.40 \\
{[0.0187]}\end{array}$ & $\begin{array}{c}11.76 \\
{[10.01]}\end{array}$ & $\begin{array}{c}4.05 \\
{[<.0001]}\end{array}$ & $\begin{array}{c}6.92 \\
{[10.24]}\end{array}$ & $\begin{array}{c}2.51 \\
{[<.0001]}\end{array}$ \\
\hline & Disp & $\begin{array}{c}5.27 \\
{[10.63]}\end{array}$ & $\begin{array}{c}1.20 \\
{[<.0001]}\end{array}$ & $\begin{array}{c}2.57 \\
{[1.71]}\end{array}$ & $\begin{array}{c}0.04 \\
{[1.0000]}\end{array}$ & $\begin{array}{c}7.32 \\
{[8.23]}\end{array}$ & $\begin{array}{c}1.92 \\
{[<.0001]}\end{array}$ & $\begin{array}{c}4.09 \\
{[6.69]}\end{array}$ & $\begin{array}{c}0.66 \\
{[0.0821]}\end{array}$ \\
\hline & Difference & $\begin{array}{l}0.0347 \\
{[4.41]}\end{array}$ & $\begin{array}{c}1.98 \\
{[<.0001]}\end{array}$ & $\begin{array}{c}2.71 \\
{[1.16]}\end{array}$ & $\begin{array}{c}1.36 \\
{[0.0328]}\end{array}$ & $\begin{array}{c}4.44 \\
{[3.01]}\end{array}$ & $\begin{array}{c}2.13 \\
{[0.0132]}\end{array}$ & $\begin{array}{c}2.83 \\
{[3.11]}\end{array}$ & $\begin{array}{c}1.95 \\
{[0.0010]}\end{array}$ \\
\hline
\end{tabular}




\section{Table 7.2: Disposition Effect and Fund Flows - Number-of-shares Weighted Disposition Spread}

This table compares the level of fund flows between funds exhibiting strong disposition effects and funds without such behavior. Every quarter and within each investment category, funds are first sorted into deciles based on their returns in the previous quarter. Funds in the same performance decile are further sorted into quintiles based on their average disposition spreads over the performance measurement period. The disposition spreads are measured in terms of number of shares. Funds in the top quintile have the highest disposition spread (Disp), and funds in the bottom quintile have the lowest disposition spread (Nondisp). In the quarter immediately after the portfolio formation period, portfolio flows are calculated by equally weighting flows to the funds included in the portfolio. Fund flow is calculated as $F L_{i, t}=\frac{T N A_{i, t}-T N A_{i, t-1}\left(1+r_{i, t}\right)}{T N A_{i, t-1}}$, where $T N A_{i, t}$ is the total net assets of fund $i$ at the end of quarter $t$, and $r_{i, t}$ is the total return of fund $i$ in quarter $t$. The time-series means and medians of the portfolio flows are reported in Panel B. We also compare fund flows on an aggregate level. Funds in the bottom 2 return deciles are grouped into Low performance group (Low), funds in the middle 6 deciles are grouped into Medium performance group (Med), and funds in the top 2 deciles are grouped into High performance group (High). Within each return group, funds with the highest disposition spread (Disp) and lowest disposition spread (Nondisp) are further grouped into portfolios. Portfolio flows are calculated by equally weighting fund flows. The time-series means and medians of portfolio flows by return groups are reported in Panel A. The portfolio analysis is performed over the whole sample period of 1980-2004, and also for three sub-sample periods divided based on the capital gains tax rate changes. T-statistics for means and p-values for medians are reported in brackets. 


\begin{tabular}{|c|c|c|c|c|c|c|c|c|c|}
\hline \multirow[t]{2}{*}{ Return } & \multirow{2}{*}{$\begin{array}{l}\text { Disposition } \\
\text { Effect }\end{array}$} & \multicolumn{2}{|c|}{$1980-2004$} & \multicolumn{2}{|c|}{ 1980-86 } & \multicolumn{2}{|c|}{$1987-97$} & \multicolumn{2}{|c|}{$1998-2004$} \\
\hline & & Mean & Median & Mean & Median & Mean & Median & Mean & Median \\
\hline \multicolumn{10}{|c|}{ Panel A: Return Group } \\
\hline \multirow[t]{3}{*}{ Low } & Nondisp & $\begin{array}{c}0.02 \\
{[0.10]}\end{array}$ & $\begin{array}{c}-1.54 \\
{[<.0001]}\end{array}$ & $\begin{array}{c}2.04 \\
{[2.31]}\end{array}$ & $\begin{array}{c}-1.10 \\
{[0.0221]}\end{array}$ & $\begin{array}{c}1.87 \\
{[4.35]}\end{array}$ & $\begin{array}{c}-0.78 \\
{[0.0000]}\end{array}$ & $\begin{array}{c}-1.66 \\
{[-5.71]}\end{array}$ & $\begin{array}{c}-2.14 \\
{[<.0001]}\end{array}$ \\
\hline & Disp & $\begin{array}{c}-1.66 \\
{[-7.97]}\end{array}$ & $\begin{array}{c}-2.38 \\
{[<.0001]}\end{array}$ & $\begin{array}{c}-1.62 \\
{[-3.16]}\end{array}$ & $\begin{array}{c}-2.51 \\
{[<.0001]}\end{array}$ & $\begin{array}{c}-0.47 \\
{[-1.27]}\end{array}$ & $\begin{array}{c}-1.76 \\
{[<.0001]}\end{array}$ & $\begin{array}{c}-2.56 \\
{[-9.72]}\end{array}$ & $\begin{array}{c}-2.81 \\
{[0.9172]}\end{array}$ \\
\hline & Difference & $\begin{array}{c}1.68 \\
{[5.26]}\end{array}$ & $\begin{array}{c}1.84 \\
{[<.0001]}\end{array}$ & $\begin{array}{c}3.66 \\
{[3.58]}\end{array}$ & $\begin{array}{c}1.41 \\
{[0.0005]}\end{array}$ & $\begin{array}{c}2.34 \\
{[4.12]}\end{array}$ & $\begin{array}{c}0.98 \\
{[<.0001]}\end{array}$ & $\begin{array}{c}0.90 \\
{[2.29]}\end{array}$ & $\begin{array}{c}0.67 \\
{[0.0028]}\end{array}$ \\
\hline \multirow[t]{3}{*}{ Med } & Nondisp & $\begin{array}{c}2.21 \\
{[14.17]}\end{array}$ & $\begin{array}{c}-0.35 \\
{[0.0000]}\end{array}$ & $\begin{array}{c}1.78 \\
{[3.73]}\end{array}$ & $\begin{array}{c}-0.30 \\
{[0.2343]}\end{array}$ & $\begin{array}{c}4.25 \\
{[14.64]}\end{array}$ & $\begin{array}{c}0.69 \\
{[0.0079]}\end{array}$ & $\begin{array}{c}0.69 \\
{[3.84]}\end{array}$ & $\begin{array}{c}-0.95 \\
{[<.0001]}\end{array}$ \\
\hline & Disp & $\begin{array}{c}0.72 \\
{[5.21]}\end{array}$ & $\begin{array}{c}-1.02 \\
{[<.0001]}\end{array}$ & $\begin{array}{c}0.03 \\
{[0.09]}\end{array}$ & $\begin{array}{c}-1.26 \\
{[<.0001]}\end{array}$ & $\begin{array}{c}1.91 \\
{[7.75]}\end{array}$ & $\begin{array}{c}-0.57 \\
{[<.0001]}\end{array}$ & $\begin{array}{c}-0.11 \\
{[-0.64]}\end{array}$ & $\begin{array}{c}-1.34 \\
{[<.0001]}\end{array}$ \\
\hline & Difference & $\begin{array}{c}1.49 \\
{[7.19]}\end{array}$ & $\begin{array}{c}0.67 \\
{[<.0001]}\end{array}$ & $\begin{array}{c}1.76 \\
{[3.10]}\end{array}$ & $\begin{array}{c}0.96 \\
{[0.0118]}\end{array}$ & $\begin{array}{c}2.34 \\
{[6.15]}\end{array}$ & $\begin{array}{c}1.26 \\
{[<.0001]}\end{array}$ & $\begin{array}{c}0.80 \\
{[3.20]}\end{array}$ & $\begin{array}{c}0.39 \\
{[<.0001]}\end{array}$ \\
\hline \multirow[t]{3}{*}{ High } & Nondisp & $\begin{array}{c}7.24 \\
{[17.56]}\end{array}$ & $\begin{array}{c}1.92 \\
{[<.0001]}\end{array}$ & $\begin{array}{c}2.37 \\
{[2.98]}\end{array}$ & $\begin{array}{c}-0.02 \\
{[0.7207]}\end{array}$ & $\begin{array}{c}10.33 \\
{[13.30]}\end{array}$ & $\begin{array}{c}3.41 \\
{[0.0000]}\end{array}$ & $\begin{array}{c}5.48 \\
{[11.48]}\end{array}$ & $\begin{array}{c}1.42 \\
{[<.0001]}\end{array}$ \\
\hline & Disp & $\begin{array}{c}4.03 \\
{[12.62]}\end{array}$ & $\begin{array}{c}0.46 \\
{[<.0001]}\end{array}$ & $\begin{array}{c}3.35 \\
{[2.97]}\end{array}$ & $\begin{array}{c}-0.66 \\
{[0.1070]}\end{array}$ & $\begin{array}{c}5.57 \\
{[9.93]}\end{array}$ & $\begin{array}{c}1.38 \\
{[<.0001]}\end{array}$ & $\begin{array}{c}2.89 \\
{[7.38]}\end{array}$ & $\begin{array}{c}-0.04 \\
{[<.0001]}\end{array}$ \\
\hline & Difference & $\begin{array}{c}3.21 \\
{[1.16]}\end{array}$ & $\begin{array}{c}1.46 \\
{[<.0001]}\end{array}$ & $\begin{array}{c}-0.98 \\
{[-0.71]}\end{array}$ & $\begin{array}{c}0.64 \\
{[0.3619]}\end{array}$ & $\begin{array}{c}4.76 \\
{[4.97]}\end{array}$ & $\begin{array}{c}2.03 \\
{[<.0001]}\end{array}$ & $\begin{array}{c}2.59 \\
{[4.20]}\end{array}$ & $\begin{array}{c}1.46 \\
{[<.0001]}\end{array}$ \\
\hline
\end{tabular}




\begin{tabular}{|c|c|c|c|c|c|c|c|c|c|}
\hline \multirow[t]{2}{*}{ Return } & \multirow{2}{*}{$\begin{array}{l}\text { Disposition } \\
\text { Effect }\end{array}$} & \multicolumn{2}{|c|}{$1980-2004$} & \multicolumn{2}{|c|}{ 1980-86 } & \multicolumn{2}{|c|}{$1987-97$} & \multicolumn{2}{|c|}{$1998-2004$} \\
\hline & & Mean & Median & Mean & Median & Mean & Median & Mean & Median \\
\hline \multicolumn{10}{|c|}{ Panel B: Return Deciles } \\
\hline \multirow[t]{3}{*}{1} & Nondisp & $\begin{array}{c}-0.58 \\
{[-1.67]}\end{array}$ & $\begin{array}{c}-2.03 \\
{[<.0001]}\end{array}$ & $\begin{array}{c}1.41 \\
{[1.14]}\end{array}$ & $\begin{array}{c}-1.21 \\
{[0.0183]}\end{array}$ & $\begin{array}{c}1.28 \\
{[2.22]}\end{array}$ & $\begin{array}{c}-1.09 \\
{[0.0110]}\end{array}$ & $\begin{array}{c}-2.27 \\
{[-5.20]}\end{array}$ & $\begin{array}{c}-2.65 \\
{[<.0001]}\end{array}$ \\
\hline & Disp & $\begin{array}{c}-2.40 \\
{[-8.19]}\end{array}$ & $\begin{array}{c}-2.91 \\
{[<.0001]}\end{array}$ & $\begin{array}{c}-2.26 \\
{[-3.30]}\end{array}$ & $\begin{array}{c}-3.00 \\
{[<.0001]}\end{array}$ & $\begin{array}{c}-1.32 \\
{[-2.70]}\end{array}$ & $\begin{array}{c}-2.20 \\
{[<.0001]}\end{array}$ & $\begin{array}{c}-3.25 \\
{[-8.11]}\end{array}$ & $\begin{array}{c}-3.29 \\
{[<.0001]}\end{array}$ \\
\hline & Difference & $\begin{array}{c}1.83 \\
{[4.05]}\end{array}$ & $\begin{array}{c}0.88 \\
{[<.0001]}\end{array}$ & $\begin{array}{c}3.67 \\
{[2.60]}\end{array}$ & $\begin{array}{c}1.79 \\
{[0.0051]}\end{array}$ & $\begin{array}{c}2.60 \\
{[3.44]}\end{array}$ & $\begin{array}{c}0.11 \\
{[0.0002]}\end{array}$ & $\begin{array}{c}0.98 \\
{[1.64]}\end{array}$ & $\begin{array}{c}0.64 \\
{[0.0315]}\end{array}$ \\
\hline \multirow[t]{3}{*}{2} & Nondisp & $\begin{array}{c}0.60 \\
{[1.75]}\end{array}$ & $\begin{array}{c}-1.21 \\
{[<.0001]}\end{array}$ & $\begin{array}{c}2.65 \\
{[2.09]}\end{array}$ & $\begin{array}{c}-0.66 \\
{[0.4426]}\end{array}$ & $\begin{array}{c}2.44 \\
{[3.85]}\end{array}$ & $\begin{array}{c}-0.35 \\
{[0.2433]}\end{array}$ & $\begin{array}{c}-1.07 \\
{[-2.79]}\end{array}$ & $\begin{array}{c}-1.61 \\
{[<.0001]}\end{array}$ \\
\hline & Disp & $\begin{array}{c}-0.93 \\
{[-3.20]}\end{array}$ & $\begin{array}{c}-2.05 \\
{[<.0001]}\end{array}$ & $\begin{array}{c}-1.00 \\
{[-1.32]}\end{array}$ & $\begin{array}{c}-2.23 \\
{[0.0003]}\end{array}$ & $\begin{array}{c}0.36 \\
{[0.64]}\end{array}$ & $\begin{array}{c}-1.02 \\
{[0.0000]}\end{array}$ & $\begin{array}{c}-1.90 \\
{[-5.55]}\end{array}$ & $\begin{array}{c}-2.46 \\
{[<.0001]}\end{array}$ \\
\hline & Difference & $\begin{array}{c}1.54 \\
{[3.41]}\end{array}$ & $\begin{array}{c}0.84 \\
{[0.0002]}\end{array}$ & $\begin{array}{c}3.65 \\
{[2.47]}\end{array}$ & $\begin{array}{c}1.57 \\
{[0.0179]}\end{array}$ & $\begin{array}{c}2.08 \\
{[2.48]}\end{array}$ & $\begin{array}{c}0.67 \\
{[0.0090]}\end{array}$ & $\begin{array}{c}0.82 \\
{[1.60]}\end{array}$ & $\begin{array}{c}0.85 \\
{[0.0171]}\end{array}$ \\
\hline \multirow[t]{3}{*}{3} & Nondisp & $\begin{array}{c}1.18 \\
{[2.91]}\end{array}$ & $\begin{array}{c}-1.12 \\
{[<.0001]}\end{array}$ & $\begin{array}{c}2.11 \\
{[1.48]}\end{array}$ & $\begin{array}{c}-0.97 \\
{[0.2000]}\end{array}$ & $\begin{array}{c}3.33 \\
{[4.28]}\end{array}$ & $\begin{array}{c}0.00 \\
{[1.0000]}\end{array}$ & $\begin{array}{c}-0.59 \\
{[-1.38]}\end{array}$ & $\begin{array}{c}-1.68 \\
{[<.0001]}\end{array}$ \\
\hline & Disp & $\begin{array}{c}-0.56 \\
{[-1.80]}\end{array}$ & $\begin{array}{c}-1.78 \\
{[<.0001]}\end{array}$ & $\begin{array}{c}-1.00 \\
{[-1.68]}\end{array}$ & $\begin{array}{c}-1.82 \\
{[0.0099]}\end{array}$ & $\begin{array}{c}0.73 \\
{[1.31]}\end{array}$ & $\begin{array}{c}-1.06 \\
{[0.0006]}\end{array}$ & $\begin{array}{c}-1.47 \\
{[-3.71]}\end{array}$ & $\begin{array}{c}-2.27 \\
{[<.0001]}\end{array}$ \\
\hline & Difference & $\begin{array}{c}1.73 \\
{[3.41]}\end{array}$ & $\begin{array}{c}0.66 \\
{[0.0003]}\end{array}$ & $\begin{array}{c}3.11 \\
{[2.02]}\end{array}$ & $\begin{array}{c}0.85 \\
{[0.0788]}\end{array}$ & $\begin{array}{c}2.60 \\
{[2.72]}\end{array}$ & $\begin{array}{c}1.06 \\
{[0.0020]}\end{array}$ & $\begin{array}{c}0.88 \\
{[1.50]}\end{array}$ & $\begin{array}{c}0.59 \\
{[0.0385]}\end{array}$ \\
\hline
\end{tabular}




\begin{tabular}{|c|c|c|c|c|c|c|c|c|c|}
\hline \multirow[t]{3}{*}{4} & Nondisp & $\begin{array}{c}1.20 \\
{[3.58]}\end{array}$ & $\begin{array}{c}-0.87 \\
{[<.0001]}\end{array}$ & $\begin{array}{c}0.99 \\
{[1.04]}\end{array}$ & $\begin{array}{c}-0.22 \\
{[0.7122]}\end{array}$ & $\begin{array}{c}3.94 \\
{[6.00]}\end{array}$ & $\begin{array}{c}0.21 \\
{[0.6621]}\end{array}$ & $\begin{array}{c}-0.88 \\
{[-2.60]}\end{array}$ & $\begin{array}{c}-1.62 \\
{[<.0001]}\end{array}$ \\
\hline & Disp & $\begin{array}{c}0.21 \\
{[0.60]}\end{array}$ & $\begin{array}{c}-1.52 \\
{[<.0001]}\end{array}$ & $\begin{array}{c}-0.16 \\
{[-0.24]}\end{array}$ & $\begin{array}{c}-1.61 \\
{[0.0187]}\end{array}$ & $\begin{array}{c}1.76 \\
{[2.61]}\end{array}$ & $\begin{array}{c}-0.90 \\
{[0.0044]}\end{array}$ & $\begin{array}{c}-0.92 \\
{[-2.13]}\end{array}$ & $\begin{array}{c}-1.92 \\
{[<.0001]}\end{array}$ \\
\hline & Difference & $\begin{array}{c}0.99 \\
{[2.01]}\end{array}$ & $\begin{array}{c}0.65 \\
{[0.0006]}\end{array}$ & $\begin{array}{c}1.16 \\
{[0.98]}\end{array}$ & $\begin{array}{c}1.39 \\
{[0.1429]}\end{array}$ & $\begin{array}{c}2.17 \\
{[2.31]}\end{array}$ & $\begin{array}{c}1.11 \\
{[0.0001]}\end{array}$ & $\begin{array}{c}0.04 \\
{[0.08]}\end{array}$ & $\begin{array}{c}0.30 \\
{[0.1945]}\end{array}$ \\
\hline \multirow[t]{3}{*}{5} & Nondisp & $\begin{array}{c}1.54 \\
{[4.31]}\end{array}$ & $\begin{array}{c}-0.65 \\
{[0.0004]}\end{array}$ & $\begin{array}{c}1.55 \\
{[1.46]}\end{array}$ & $\begin{array}{c}-0.35 \\
{[0.7035]}\end{array}$ & $\begin{array}{c}2.49 \\
{[4.32]}\end{array}$ & $\begin{array}{c}-0.02 \\
{[1.0000]}\end{array}$ & $\begin{array}{c}0.77 \\
{[1.56]}\end{array}$ & $\begin{array}{c}-1.48 \\
{[<.0001]}\end{array}$ \\
\hline & Disp & $\begin{array}{c}0.57 \\
{[1.70]}\end{array}$ & $\begin{array}{c}-0.95 \\
{[<.0001]}\end{array}$ & $\begin{array}{c}0.22 \\
{[0.25]}\end{array}$ & $\begin{array}{c}-1.16 \\
{[0.2074]}\end{array}$ & $\begin{array}{c}1.85 \\
{[3.23]}\end{array}$ & $\begin{array}{c}-0.42 \\
{[0.1167]}\end{array}$ & $\begin{array}{c}-0.40 \\
{[-0.93]}\end{array}$ & $\begin{array}{c}-1.44 \\
{[<.0001]}\end{array}$ \\
\hline & Difference & $\begin{array}{c}0.97 \\
{[1.99]}\end{array}$ & $\begin{array}{c}0.30 \\
{[0.0940]}\end{array}$ & $\begin{array}{c}1.33 \\
{[0.97]}\end{array}$ & $\begin{array}{c}0.81 \\
{[0.2581]}\end{array}$ & $\begin{array}{c}0.65 \\
{[0.79]}\end{array}$ & $\begin{array}{c}0.40 \\
{[0.1790]}\end{array}$ & $\begin{array}{c}1.17 \\
{[1.79]}\end{array}$ & $\begin{array}{c}0.04 \\
{[0.2021]}\end{array}$ \\
\hline \multirow[t]{3}{*}{6} & Nondisp & $\begin{array}{c}2.73 \\
{[7.36]}\end{array}$ & $\begin{array}{c}0.18 \\
{[0.5289]}\end{array}$ & $\begin{array}{c}2.17 \\
{[1.86]}\end{array}$ & $\begin{array}{c}0.01 \\
{[0.7982]}\end{array}$ & $\begin{array}{c}4.55 \\
{[7.09]}\end{array}$ & $\begin{array}{c}1.69 \\
{[0.0007]}\end{array}$ & $\begin{array}{c}1.41 \\
{[2.99]}\end{array}$ & $\begin{array}{c}-0.52 \\
{[0.0295]}\end{array}$ \\
\hline & Disp & $\begin{array}{c}0.69 \\
{[2.34]}\end{array}$ & $\begin{array}{c}-0.78 \\
{[0.0000]}\end{array}$ & $\begin{array}{c}-1.05 \\
{[-1.95]}\end{array}$ & $\begin{array}{c}-1.54 \\
{[0.0007]}\end{array}$ & $\begin{array}{c}1.49 \\
{[2.98]}\end{array}$ & $\begin{array}{c}-0.25 \\
{[0.2462]}\end{array}$ & $\begin{array}{c}0.32 \\
{[0.79]}\end{array}$ & $\begin{array}{c}-0.92 \\
{[0.0002]}\end{array}$ \\
\hline & Difference & $\begin{array}{c}2.04 \\
{[4.31]}\end{array}$ & $\begin{array}{c}0.12 \\
{[<.0001]}\end{array}$ & $\begin{array}{c}3.22 \\
{[2.51]}\end{array}$ & $\begin{array}{c}2.55 \\
{[0.0378]}\end{array}$ & $\begin{array}{c}3.05 \\
{[3.76]}\end{array}$ & $\begin{array}{c}1.94 \\
{[<.0001]}\end{array}$ & $\begin{array}{c}1.09 \\
{[1.76]}\end{array}$ & $\begin{array}{c}0.40 \\
{[0.0414]}\end{array}$ \\
\hline \multirow[t]{3}{*}{7} & Nondisp & $\begin{array}{c}2.74 \\
{[7.62]}\end{array}$ & $\begin{array}{c}0.06 \\
{[0.7036]}\end{array}$ & $\begin{array}{c}0.90 \\
{[1.01]}\end{array}$ & $\begin{array}{c}-0.51 \\
{[0.4426]}\end{array}$ & $\begin{array}{c}5.03 \\
{[7.37]}\end{array}$ & $\begin{array}{c}1.31 \\
{[0.0004]}\end{array}$ & $\begin{array}{c}1.20 \\
{[2.98]}\end{array}$ & $\begin{array}{c}-0.47 \\
{[0.0269]}\end{array}$ \\
\hline & Disp & $\begin{array}{c}1.39 \\
{[3.99]}\end{array}$ & $\begin{array}{c}-0.78 \\
{[0.0001]}\end{array}$ & $\begin{array}{c}0.26 \\
{[0.35]}\end{array}$ & $\begin{array}{c}-1.01 \\
{[0.1550]}\end{array}$ & $\begin{array}{c}2.24 \\
{[3.73]}\end{array}$ & $\begin{array}{c}-0.49 \\
{[0.1167]}\end{array}$ & $\begin{array}{c}0.87 \\
{[1.89]}\end{array}$ & $\begin{array}{c}-0.88 \\
{[0.0005]}\end{array}$ \\
\hline & Difference & $\begin{array}{c}1.35 \\
{[2.70]}\end{array}$ & $\begin{array}{c}0.84 \\
{[0.0001]}\end{array}$ & $\begin{array}{c}0.64 \\
{[0.55]}\end{array}$ & $\begin{array}{c}0.50 \\
{[0.3084]}\end{array}$ & $\begin{array}{c}2.78 \\
{[3.06]}\end{array}$ & $\begin{array}{c}1.80 \\
{[<.0001]}\end{array}$ & $\begin{array}{c}0.33 \\
{[0.53]}\end{array}$ & $\begin{array}{c}0.41 \\
{[0.0596]}\end{array}$ \\
\hline
\end{tabular}




\begin{tabular}{|c|c|c|c|c|c|c|c|c|c|}
\hline \multirow[t]{3}{*}{8} & Nondisp & $\begin{array}{c}3.88 \\
{[8.65]}\end{array}$ & $\begin{array}{c}0.51 \\
{[0.0247]}\end{array}$ & $\begin{array}{c}3.01 \\
{[2.08]}\end{array}$ & $\begin{array}{c}-0.16 \\
{[1.0000]}\end{array}$ & $\begin{array}{c}6.15 \\
{[7.01]}\end{array}$ & $\begin{array}{c}1.20 \\
{[0.0028]}\end{array}$ & $\begin{array}{c}2.24 \\
{[4.78]}\end{array}$ & $\begin{array}{c}0.20 \\
{[0.6317]}\end{array}$ \\
\hline & Disp & $\begin{array}{c}1.98 \\
{[5.47]}\end{array}$ & $\begin{array}{c}-0.40 \\
{[0.0226]}\end{array}$ & $\begin{array}{c}1.85 \\
{[2.04]}\end{array}$ & $\begin{array}{c}0.19 \\
{[1.0000]}\end{array}$ & $\begin{array}{c}3.34 \\
{[4.89]}\end{array}$ & $\begin{array}{c}-0.33 \\
{[0.1751]}\end{array}$ & $\begin{array}{c}0.94 \\
{[2.21]}\end{array}$ & $\begin{array}{c}-0.61 \\
{[0.0495]}\end{array}$ \\
\hline & Difference & $\begin{array}{c}1.90 \\
{[3.30]}\end{array}$ & $\begin{array}{c}0.91 \\
{[0.0001]}\end{array}$ & $\begin{array}{c}1.16 \\
{[0.68]}\end{array}$ & $\begin{array}{c}-0.35 \\
{[0.4573]}\end{array}$ & $\begin{array}{c}2.81 \\
{[2.53]}\end{array}$ & $\begin{array}{c}1.53 \\
{[0.0046]}\end{array}$ & $\begin{array}{c}1.30 \\
2.06]\end{array}$ & $\begin{array}{c}0.81 \\
{[0.0030]}\end{array}$ \\
\hline \multirow[t]{3}{*}{9} & Nondisp & $\begin{array}{c}5.34 \\
{[10.57]}\end{array}$ & $\begin{array}{c}1.19 \\
{[<.0001]}\end{array}$ & $\begin{array}{c}2.02 \\
{[1.56]}\end{array}$ & $\begin{array}{c}-0.46 \\
{[0.2451]}\end{array}$ & $\begin{array}{c}7.56 \\
{[8.28]}\end{array}$ & $\begin{array}{c}2.19 \\
{[<.0001]}\end{array}$ & $\begin{array}{c}4.00 \\
{[6.55]}\end{array}$ & $\begin{array}{c}0.70 \\
{[0.0136]}\end{array}$ \\
\hline & Disp & $\begin{array}{c}3.11 \\
{[8.27]}\end{array}$ & $\begin{array}{c}-0.02 \\
{[0.8329]}\end{array}$ & $\begin{array}{c}3.19 \\
{[2.48]}\end{array}$ & $\begin{array}{c}-0.07 \\
{[0.8974]}\end{array}$ & $\begin{array}{c}4.14 \\
{[6.95]}\end{array}$ & $\begin{array}{c}1.04 \\
{[0.1031]}\end{array}$ & $\begin{array}{c}2.25 \\
{[4.33]}\end{array}$ & $\begin{array}{c}-0.36 \\
{[0.0838]}\end{array}$ \\
\hline & Difference & $\begin{array}{c}2.23 \\
{[3.54]}\end{array}$ & $\begin{array}{c}1.21 \\
{[0.0009]}\end{array}$ & $\begin{array}{c}-1.17 \\
{[-0.64]}\end{array}$ & $\begin{array}{c}-0.39 \\
{[0.1324]}\end{array}$ & $\begin{array}{c}3.42 \\
{[3.14]}\end{array}$ & $\begin{array}{c}1.15 \\
{[0.0060]}\end{array}$ & $\begin{array}{c}1.74 \\
{[2.17]}\end{array}$ & $\begin{array}{c}1.06 \\
{[0.0063]}\end{array}$ \\
\hline \multirow[t]{3}{*}{10} & Nondisp & $\begin{array}{c}9.12 \\
{[14.16]}\end{array}$ & $\begin{array}{c}3.18 \\
{[<.0001]}\end{array}$ & $\begin{array}{c}2.69 \\
{[2.81]}\end{array}$ & $\begin{array}{c}0.89 \\
{[0.6201]}\end{array}$ & $\begin{array}{c}13.18 \\
{[10.57]}\end{array}$ & $\begin{array}{c}5.01 \\
{[<.0001]}\end{array}$ & $\begin{array}{c}6.93 \\
{[9.55]}\end{array}$ & $\begin{array}{c}2.40 \\
{[<.0001]}\end{array}$ \\
\hline & Disp & $\begin{array}{c}4.94 \\
{[9.63]}\end{array}$ & $\begin{array}{c}1.11 \\
{[0.0001]}\end{array}$ & $\begin{array}{c}3.50 \\
{[1.91]}\end{array}$ & $\begin{array}{c}-0.93 \\
{[0.0464]}\end{array}$ & $\begin{array}{c}7.04 \\
{[7.39]}\end{array}$ & $\begin{array}{c}1.82 \\
{[<.0001]}\end{array}$ & $\begin{array}{c}3.51 \\
{[6.02]}\end{array}$ & $\begin{array}{c}0.85 \\
{[0.1312]}\end{array}$ \\
\hline & Difference & $\begin{array}{c}4.19 \\
{[5.08]}\end{array}$ & $\begin{array}{c}1.97 \\
{[<.0001]}\end{array}$ & $\begin{array}{c}-0.81 \\
{[-0.39]}\end{array}$ & $\begin{array}{c}1.82 \\
{[0.0622]}\end{array}$ & $\begin{array}{c}6.14 \\
{[3.91]}\end{array}$ & $\begin{array}{c}3.19 \\
{[0.0011]}\end{array}$ & $\begin{array}{c}3.42 \\
{[3.68]}\end{array}$ & $\begin{array}{c}1.55 \\
{[0.0004]}\end{array}$ \\
\hline
\end{tabular}




\section{Table 8.1: Disposition Effect and Fund Flows Regression Results - Value-weighted Disposition Spread}

This table examines the influence of the disposition effect on fund flows and flow-performance relationship. Each quarter and within each investment objective categories, all funds are ranked based on their previous quarter returns, and assigned a continuous rank ranging from zero (worst) to one (best), with the rankings corresponding to their performance percentiles. Funds in the bottom return deciles are aggregated into Low group (Low), the middle 6 deciles into Medium performance group (Med) and the top 2 deciles into High performance group (High). The factional rank for funds in Low group is defined as Min (Rank, 0.2). Funds in Med group receive ranks defined as Min (0.6, Rank - Low). Funds in High group are defined as Rank -Mid - Low. Each quarter a piecewise linear regression is performed by regressing quarterly flows on funds' fractional performance ranks over the low, medium and high performance ranges, and funds' average disposition spreads over the measurement period as in equation (8): Flow $_{i, t}=\alpha+b_{1} \times$ Low $_{i, t-1}+b_{2} \times$ Med $_{i, t-1}+b_{3} \times$ High $_{i, t-1}+b_{4} \times$ Disp $_{i, t-1}+$ Controls $+\varepsilon_{i, t}$,

or the interaction terms of performance rank with funds' average disposition spread over the measurement period as in equation (9): Flow $_{i, t}=\alpha_{i, t}+b_{1} \times \operatorname{Low}_{i, t-1}+\beta_{1} \times \operatorname{Low}_{i, t-1} \times \operatorname{Disp}_{i, t-1}+b_{2} \times \operatorname{Med}_{i, t-1}+\beta_{2} \times \operatorname{Med}_{i, t-1} \times \operatorname{Disp}_{i, t-1}$ $+b_{3} \times$ High $_{i, t-1}+\beta_{3} \times$ High $_{i, t-1} \times$ Disp $_{i, t-1}+$ Controls $+\varepsilon_{i, t}$

The disposition spreads are measured in terms of dollar value. The control variables include volatility of monthly returns during the disposition effect measurement period, fund age, natural log of fund size measured by the previous year-end total net asset value, aggregate flow into the fund objective category, expense ratio, and total fee ratio. Regressions are conducted over the whole sample period and also over three sub-sample periods. Time-series average coefficients from Fama-MacBeth regressions and t-statistics (in parentheses) are reported. *, **, and *** denote significance at $10 \%, 5 \%$ and $1 \%$ level, respectively. 


\begin{tabular}{|c|c|c|c|c|}
\hline \multicolumn{5}{|c|}{ Panel A: Equation (8) } \\
\hline & $1980-2004$ & $1980-86$ & 1987-97 & 1998-2004 \\
\hline Intercept & $\begin{array}{l}-0.0111^{* *} \\
{[-1.83]}\end{array}$ & $\begin{array}{l}-0.0353 * * * \\
{[-3.22]}\end{array}$ & $\begin{array}{l}0.0097 \\
{[1.06]}\end{array}$ & $\begin{array}{l}-0.0238 * * * \\
{[-2.26]}\end{array}$ \\
\hline Low & $\begin{array}{l}0.1021^{* * *} \\
{[7.19]}\end{array}$ & $\begin{array}{l}0.0711^{* * *} \\
{[1.98]}\end{array}$ & $\begin{array}{l}0.1358^{* * *} \\
{[6.30]}\end{array}$ & $\begin{array}{l}0.0846^{* * *} \\
{[5.07]}\end{array}$ \\
\hline Mid & $\begin{array}{l}0.0350 * * * \\
{[8.39]}\end{array}$ & $\begin{array}{l}0.0183^{* * *} \\
{[2.23]}\end{array}$ & $\begin{array}{l}0.0359 * * * \\
{[6.59]}\end{array}$ & $\begin{array}{l}0.0506^{* * *} \\
{[5.90]}\end{array}$ \\
\hline High & $\begin{array}{l}0.1857 * * * \\
{[9.40]}\end{array}$ & $\begin{array}{l}0.0996 * * * \\
{[3.11]}\end{array}$ & $\begin{array}{l}0.2354^{* * *} \\
{[6.82]}\end{array}$ & $\begin{array}{l}0.1832^{* * *} \\
{[6.54]}\end{array}$ \\
\hline Disposition & $\begin{array}{l}-0.0122^{* * *} \\
{[-5.19]}\end{array}$ & $\begin{array}{l}-0.0115^{* * *} \\
{[-2.89]}\end{array}$ & $\begin{array}{l}-0.0176^{* * *} \\
{[-3.47]}\end{array}$ & $\begin{array}{l}-0.0096 * * * \\
{[-3.15]}\end{array}$ \\
\hline Category Flow & $\begin{array}{l}0.0048^{* * * *} \\
{[3.92]}\end{array}$ & $\begin{array}{l}0.0086^{* * *} \\
{[2.93]}\end{array}$ & $\begin{array}{l}0.0042 * * * \\
{[2.02]}\end{array}$ & $\begin{array}{l}0.0013^{* * *} \\
{[3.79]}\end{array}$ \\
\hline Volatility & $\begin{array}{l}-0.2501 \\
{[-1.66]}\end{array}$ & $\begin{array}{l}-0.1599 \\
{[-0.96]}\end{array}$ & $\begin{array}{l}-0.2916^{* *} \\
{[-1.84]}\end{array}$ & $\begin{array}{l}-0.2380 \\
{[-1.56]}\end{array}$ \\
\hline Age & $\begin{array}{l}-0.0008^{* * *} \\
{[-13.03]}\end{array}$ & $\begin{array}{l}-0.0008 * * * \\
{[-6.47]}\end{array}$ & $\begin{array}{l}-0.0011^{* * *} \\
{[-9.93]}\end{array}$ & $\begin{array}{l}-0.0006^{* * *} \\
{[-9.34]}\end{array}$ \\
\hline Size & $\begin{array}{l}0.0010 \\
{[1.53]}\end{array}$ & $\begin{array}{l}0.0066^{* * *} \\
{[4.60]}\end{array}$ & $\begin{array}{l}-0.0019 * * * \\
{[-1.96]}\end{array}$ & $\begin{array}{l}0.0009 \\
{[1.48]}\end{array}$ \\
\hline Expenses & $\begin{array}{l}0.3071 * * * \\
{[2.24]}\end{array}$ & $\begin{array}{l}1.7223^{* * *} \\
{[5.67]}\end{array}$ & $\begin{array}{l}-0.3317^{* *} \\
{[-1.92]}\end{array}$ & $\begin{array}{l}0.1319 * \\
{[1.77]}\end{array}$ \\
\hline Total Fee & $\begin{array}{l}-0.0005 \\
{[-0.36]}\end{array}$ & $\begin{array}{l}-0.0009 \\
{[-0.39]}\end{array}$ & $\begin{array}{l}-0.0064^{* * *} \\
{[-2.36]}\end{array}$ & $\begin{array}{l}0.0088 * * * \\
{[6.53]}\end{array}$ \\
\hline Lag Flow & $\begin{array}{l}0.1815^{* * *} \\
{[9.68]}\end{array}$ & $\begin{array}{l}0.2307 * * * \\
{[5.03]}\end{array}$ & $\begin{array}{l}0.1486 * * * \\
{[5.17]}\end{array}$ & $\begin{array}{l}0.1757^{* * *} \\
{[7.60]}\end{array}$ \\
\hline Adj. $\mathrm{R}^{2}$ & 0.21 & 0.24 & 0.20 & 0.20 \\
\hline
\end{tabular}




\begin{tabular}{|c|c|c|c|c|}
\hline & \multicolumn{4}{|c|}{ Panel B: Equation (8) without Performance Variables } \\
\hline & 1980-2004 & $1980-86$ & 1987-97 & 1998-2004 \\
\hline Intercept & $\begin{array}{l}-0.0032 * * * \\
{[2.18]}\end{array}$ & $\begin{array}{l}-0.0187 * * * \\
{[-2.15]}\end{array}$ & $\begin{array}{l}0.0431^{* * *} \\
{[4.33]}\end{array}$ & $\begin{array}{l}-0.0307 \\
{[-0.33]}\end{array}$ \\
\hline Disposition & $\begin{array}{l}-0.0156^{* * *} \\
{[-6.19]}\end{array}$ & $\begin{array}{l}-0.0155^{* * *} \\
{[-3.89]}\end{array}$ & $\begin{array}{l}-0.0196 * * * \\
{[-3.89]}\end{array}$ & $\begin{array}{l}-0.106^{* * *} \\
{[-3.35]}\end{array}$ \\
\hline Category Flow & $\begin{array}{l}0.0012^{* * *} \\
{[3.79]}\end{array}$ & $\begin{array}{l}0.0081^{* * *} \\
{[3.03]}\end{array}$ & $\begin{array}{l}0.0046^{* * *} \\
{[2.00]}\end{array}$ & $\begin{array}{l}0.0015^{* * *} \\
{[3.72]}\end{array}$ \\
\hline Volatility & $\begin{array}{l}-0.3862 * * * \\
{[-2.11]}\end{array}$ & $\begin{array}{l}-0.0879 \\
{[-0.67]}\end{array}$ & $\begin{array}{l}-0.5036 * * * \\
{[-3.28]}\end{array}$ & $\begin{array}{l}-0.3135 \\
{[-0.73]}\end{array}$ \\
\hline Age & $\begin{array}{l}-0.0006^{* * *} \\
{[-12.99]}\end{array}$ & $\begin{array}{l}-0.0008 * * * \\
{[-6.21]}\end{array}$ & $\begin{array}{l}-0.0011^{* * *} \\
{[-10.04]}\end{array}$ & $\begin{array}{l}-0.0007 * * * \\
{[-10.73]}\end{array}$ \\
\hline Size & $\begin{array}{l}0.0016^{* * * *} \\
{[2.24]}\end{array}$ & $\begin{array}{l}0.0069 * * * \\
{[4.49]}\end{array}$ & $\begin{array}{l}-0.0014 \\
{[-1.41]}\end{array}$ & $\begin{array}{l}0.0022 * * * \\
{[2.84]}\end{array}$ \\
\hline Expenses & $\begin{array}{l}0.1830 * \\
{[1.67]}\end{array}$ & $\begin{array}{l}1.6569 * * * \\
{[5.62]}\end{array}$ & $\begin{array}{l}-0.4940 * * * \\
{[-2.92]}\end{array}$ & $\begin{array}{l}0.2781^{* * *} \\
{[2.20]}\end{array}$ \\
\hline Total Fee & $\begin{array}{l}-0.0010 \\
{[-0.64]}\end{array}$ & $\begin{array}{l}-0.0010 \\
{[-0.48]}\end{array}$ & $\begin{array}{l}-0.0068^{* *} \\
{[-2.59]}\end{array}$ & $\begin{array}{l}0.0080^{* * *} \\
{[5.56]}\end{array}$ \\
\hline Lag Flow & $\begin{array}{l}0.1889 * * * \\
{[9.81]}\end{array}$ & $\begin{array}{l}0.2410^{* * *} \\
{[5.12]}\end{array}$ & $\begin{array}{l}0.1513^{* *} \\
{[5.22]}\end{array}$ & $\begin{array}{l}0.1878^{* * * *} \\
{[7.52]}\end{array}$ \\
\hline Adj. $\mathrm{R}^{2}$ & 0.18 & 0.22 & 0.17 & 0.16 \\
\hline
\end{tabular}




\begin{tabular}{|c|c|c|c|c|}
\hline \multicolumn{5}{|c|}{ Panel C: Equation (9) } \\
\hline & $1980-2004$ & $1980-86$ & 1987-97 & 1998-2004 \\
\hline Intercept & $\begin{array}{l}-0.0106^{* *} \\
{[-1.76]}\end{array}$ & $\begin{array}{l}-0.0365 * * * \\
{[-3.17]}\end{array}$ & $\begin{array}{l}0.0096 \\
{[1.07]}\end{array}$ & $\begin{array}{l}-0.0220 * * * \\
{[-2.14]}\end{array}$ \\
\hline Low & $\begin{array}{l}0.0985^{* * *} \\
{[6.75]}\end{array}$ & $\begin{array}{l}0.0549 \\
{[1.52]}\end{array}$ & $\begin{array}{l}0.1367 * * * \\
{[6.16]}\end{array}$ & $\begin{array}{l}0.0861 * * * \\
{[5.20]}\end{array}$ \\
\hline Low*Disp & $\begin{array}{l}-0.0354 * * \\
{[-1.72]}\end{array}$ & $\begin{array}{l}-0.1307 * * * \\
{[-3.28]}\end{array}$ & $\begin{array}{l}-0.0300 * * * \\
{[-0.84]}\end{array}$ & $\begin{array}{l}0.0283 \\
{[1.24]}\end{array}$ \\
\hline Mid & $\begin{array}{l}0.0341^{* * *} \\
{[7.40]}\end{array}$ & $\begin{array}{l}0.194^{* * *} \\
{[2.10]}\end{array}$ & $\begin{array}{l}0.0331^{* * *} \\
{[5.37]}\end{array}$ & $\begin{array}{l}0.0512 * * * \\
{[5.53]}\end{array}$ \\
\hline Mid*Disp & $\begin{array}{l}-0.0070 \\
{[-0.57]}\end{array}$ & $\begin{array}{l}0.0144 \\
{[0.50]}\end{array}$ & $\begin{array}{l}-0.0155 \\
{[-0.77]}\end{array}$ & $\begin{array}{l}-0.0108 \\
{[-0.77]}\end{array}$ \\
\hline High & $\begin{array}{l}0.1817^{* * *} \\
{[9.40]}\end{array}$ & $\begin{array}{l}0.1035^{* * *} \\
{[2.82]}\end{array}$ & $\begin{array}{l}0.2227^{* * *} \\
{[6.61]}\end{array}$ & $\begin{array}{l}0.1809 * * * \\
{[7.55]}\end{array}$ \\
\hline High*Disp & $\begin{array}{l}-0.0687 \\
{[-1.20]}\end{array}$ & $\begin{array}{l}-0.0901 \\
{[-0.87]}\end{array}$ & $\begin{array}{l}-0.0966 \\
{[-0.92]}\end{array}$ & $\begin{array}{l}-0.0386 \\
{[-0.54]}\end{array}$ \\
\hline Category Flow & $\begin{array}{l}0.0053^{* * *} \\
{[4.34]}\end{array}$ & $\begin{array}{l}0.0106^{* * *} \\
{[3.55]}\end{array}$ & $\begin{array}{l}0.0039 * * * \\
{[2.04]}\end{array}$ & $\begin{array}{l}0.0013^{* * *} \\
{[3.75]}\end{array}$ \\
\hline Volatility & $\begin{array}{l}0.0300 \\
{[0.31]}\end{array}$ & $\begin{array}{l}-0.1385 \\
{[-0.84]}\end{array}$ & $\begin{array}{l}0.2993^{* *} \\
{[1.89]}\end{array}$ & $\begin{array}{l}-0.2534^{*} \\
{[-1.66]}\end{array}$ \\
\hline Age & $\begin{array}{l}-0.0008^{* * *} \\
{[-13.14]}\end{array}$ & $\begin{array}{l}-0.0009 * * * \\
{[-6.66]}\end{array}$ & $\begin{array}{l}-0.0011^{* * *} \\
{[-10.06]}\end{array}$ & $\begin{array}{l}-0.0006 * * * \\
{[-9.37]}\end{array}$ \\
\hline Size & $\begin{array}{l}0.0011^{*} \\
{[1.66]}\end{array}$ & $\begin{array}{l}0.0071^{* * *} \\
{[4.83]}\end{array}$ & $\begin{array}{l}-0.0019 * * * \\
{[-2.01]}\end{array}$ & $\begin{array}{l}0.0009 \\
{[1.46]}\end{array}$ \\
\hline Expenses & $\begin{array}{l}0.3301^{* * * *} \\
{[2.30]}\end{array}$ & $\begin{array}{l}1.8238^{* * *} \\
{[5.81]}\end{array}$ & $\begin{array}{l}-0.2968 * \\
{[-1.65]}\end{array}$ & $\begin{array}{l}0.1182^{*} \\
{[1.69]}\end{array}$ \\
\hline Total Fee & $\begin{array}{l}-0.0008 \\
{[-0.49]}\end{array}$ & $\begin{array}{l}-0.0010 \\
{[-0.48]}\end{array}$ & $\begin{array}{l}-0.0066^{* *} \\
{[-2.38]}\end{array}$ & $\begin{array}{l}0.0088^{* * *} \\
{[6.74]}\end{array}$ \\
\hline Lag Flow & $\begin{array}{l}0.1819^{* * * *} \\
{[9.72]}\end{array}$ & $\begin{array}{l}0.2301^{* * *} \\
{[4.96]}\end{array}$ & $\begin{array}{l}0.1492^{* *} \\
{[5.26]}\end{array}$ & $\begin{array}{l}0.1773^{* * *} \\
{[7.61]}\end{array}$ \\
\hline Adj. $\mathrm{R}^{2}$ & 0.21 & 0.23 & 0.20 & 0.20 \\
\hline
\end{tabular}




\section{Table 8.2: Disposition Effect and Fund Flows Regression Results - Number-of-shares Weighted Disposition Spread}

This table examines the influence of the disposition effect on fund flows and flow-performance relationship. Each quarter and within each investment objective categories, all funds are ranked based on their previous quarter returns, and assigned a continuous rank ranging from zero (worst) to one (best), with the rankings corresponding to their performance percentiles. Funds in the bottom return deciles are aggregated into Low group (Low), the middle 6 deciles into Medium performance group (Med) and the top 2 deciles into High performance group (High). The factional rank for funds in Low group is defined as Min (Rank, 0.2). Funds in Med group receive ranks defined as Min (0.6, Rank - Low). Funds in High group are defined as Rank -Mid - Low. Each quarter a piecewise linear regression is performed by regressing quarterly flows on funds' fractional performance ranks over the low, medium and high performance ranges, and funds' average disposition spreads over the measurement period as in equation (7): Flow $_{i, t}=\alpha+b_{1} \times$ Low $_{i, t-1}+b_{2} \times$ Med $_{i, t-1}+b_{3} \times$ High $_{i, t-1}+b_{4} \times$ Disp $_{i, t-1}+$ Controls $+\varepsilon_{i, t}$,

or the interaction terms of performance rank with funds' average disposition spread over the measurement period as in equation Flow $_{i, t}=\alpha_{i, t}+b_{1} \times \operatorname{Low}_{i, t-1}+\beta_{1} \times \operatorname{Low}_{i, t-1} \times \operatorname{Disp}_{i, t-1}+b_{2} \times \operatorname{Med}_{i, t-1}+\beta_{2} \times \operatorname{Med}_{i, t-1} \times \operatorname{Disp}_{i, t-1}$ $+b_{3} \times$ High $_{i, t-1}+\beta_{3} \times$ High $_{i, t-1} \times$ Disp $_{i, t-1}+$ Controls $+\varepsilon_{i, t}$

The disposition spreads are measured in terms of number of shares. The control variables include volatility of monthly returns during the disposition effect measurement period, fund age, natural log of fund size measured by the previous year-end total net asset value, aggregate flow into the fund objective category, expense ratio, and total fee ratio. Regressions are conducted over the whole sample period and also over three sub-sample periods. Time-series average coefficients from Fama-MacBeth regressions and t-statistics (in parentheses) are reported. *, **, and *** denote significance at $10 \%, 5 \%$ and $1 \%$ level, respectively. 


\begin{tabular}{|c|c|c|c|c|}
\hline \multicolumn{5}{|c|}{ Panel A: Equation (8) } \\
\hline & 1980-2004 & 1980-86 & 1987-97 & 1998-2004 \\
\hline Intercept & $\begin{array}{l}-0.0101^{* *} \\
{[-1.66]}\end{array}$ & $\begin{array}{l}-0.0358 * * * \\
{[-3.25]}\end{array}$ & $\begin{array}{l}0.0114 \\
{[1.24]}\end{array}$ & $\begin{array}{l}-0.0228 * * * \\
{[-2.18]}\end{array}$ \\
\hline Low & $\begin{array}{l}0.1016^{* * *} \\
{[7.11]}\end{array}$ & $\begin{array}{l}0.0699 * * * \\
{[1.93]}\end{array}$ & $\begin{array}{l}0.1357 * * * \\
{[6.25]}\end{array}$ & $\begin{array}{l}0.0841^{* * *} \\
{[5.05]}\end{array}$ \\
\hline Mid & $\begin{array}{l}0.0347 * * * \\
{[8.34]}\end{array}$ & $\begin{array}{l}0.0186^{* * *} \\
{[2.19]}\end{array}$ & $\begin{array}{l}0.0353^{* * *} \\
{[6.48]}\end{array}$ & $\begin{array}{l}0.0503^{* * *} \\
{[6.00]}\end{array}$ \\
\hline High & $\begin{array}{l}0.1867 * * * \\
{[9.45]}\end{array}$ & $\begin{array}{l}0.1025^{* * *} \\
{[3.22]}\end{array}$ & $\begin{array}{l}0.2360 * * * \\
{[6.81]}\end{array}$ & $\begin{array}{l}0.1828^{* * *} \\
{[6.53]}\end{array}$ \\
\hline Disposition & $\begin{array}{l}-0.0318^{* * *} \\
{[-9.01]}\end{array}$ & $\begin{array}{l}-0.0280 * * * \\
{[-4.44]}\end{array}$ & $\begin{array}{l}-0.0376^{* * *} \\
{[-6.10]}\end{array}$ & $\begin{array}{l}-0.0281^{* * *} \\
{[-5.50]}\end{array}$ \\
\hline Category Flow & $\begin{array}{l}0.0049 * * * \\
{[3.90]}\end{array}$ & $\begin{array}{l}0.0089 * * * \\
{[2.97]}\end{array}$ & $\begin{array}{l}0.0043^{* * * *} \\
{[1.99]}\end{array}$ & $\begin{array}{l}0.0013^{* * *} \\
{[3.68]}\end{array}$ \\
\hline Volatility & $\begin{array}{l}0.0126 \\
{[0.13]}\end{array}$ & $\begin{array}{l}-0.1434 \\
{[-0.83]}\end{array}$ & $\begin{array}{l}0.2625^{* *} \\
{[1.66]}\end{array}$ & $\begin{array}{l}-0.2496 \\
{[-1.65]}\end{array}$ \\
\hline Age & $\begin{array}{l}-0.0009 * * * \\
{[-13.13]}\end{array}$ & $\begin{array}{l}-0.0009 * * * \\
{[-6.58]}\end{array}$ & $\begin{array}{l}-0.0011^{* * *} \\
{[-9.95]}\end{array}$ & $\begin{array}{l}-0.0006 * * * \\
{[-9.33]}\end{array}$ \\
\hline Size & $\begin{array}{l}0.0011 \\
{[1.67]}\end{array}$ & $\begin{array}{l}0.0069 * * * \\
{[4.94]}\end{array}$ & $\begin{array}{l}-0.0019 * * * \\
{[-1.96]}\end{array}$ & $\begin{array}{l}0.0009 \\
{[1.56]}\end{array}$ \\
\hline Expenses & $\begin{array}{l}0.3060^{* * *} \\
{[2.21]}\end{array}$ & $\begin{array}{l}1.7410^{* * *} \\
{[5.67]}\end{array}$ & $\begin{array}{l}-0.3510^{* *} \\
{[-2.06]}\end{array}$ & $\begin{array}{l}0.1450 * \\
{[1.88]}\end{array}$ \\
\hline Total Fee & $\begin{array}{l}-0.0007 \\
{[-0.47]}\end{array}$ & $\begin{array}{l}-0.0010 \\
{[-0.47]}\end{array}$ & $\begin{array}{l}-0.0067 * * * \\
{[-2.45]}\end{array}$ & $\begin{array}{l}0.0089 * * * \\
{[6.66]}\end{array}$ \\
\hline Lag Flow & $\begin{array}{l}0.1803^{* * *} \\
{[9.64]}\end{array}$ & $\begin{array}{l}0.2282 * * * \\
{[4.96]}\end{array}$ & $\begin{array}{l}0.1481^{* * *} \\
{[5.17]}\end{array}$ & $\begin{array}{l}0.1745^{* * *} \\
{[7.59]}\end{array}$ \\
\hline Adj. $\mathrm{R}^{2}$ & 0.21 & 0.24 & 0.22 & 0.20 \\
\hline
\end{tabular}




\begin{tabular}{|c|c|c|c|c|}
\hline & \multicolumn{4}{|c|}{ Panel B: Equation (8) without Performance Variables } \\
\hline & 1980-2004 & $1980-86$ & 1987-97 & 1998-2004 \\
\hline Intercept & $\begin{array}{l}0.0151^{* * *} \\
{[2.41]}\end{array}$ & $\begin{array}{l}-0.0184 * * * \\
{[-2.21]}\end{array}$ & $\begin{array}{l}0.0450 * * * \\
{[4.52]}\end{array}$ & $\begin{array}{l}-0.0016 \\
{[-0.17]}\end{array}$ \\
\hline Disposition & $\begin{array}{l}-0.0353^{* * *} \\
{[-9.01]}\end{array}$ & $\begin{array}{l}-0.0285 * * * \\
{[-4.44]}\end{array}$ & $\begin{array}{l}-0.0407 * * * \\
{[-6.66]}\end{array}$ & $\begin{array}{l}-0.0348 * * * \\
{[-4.33]}\end{array}$ \\
\hline Category Flow & $\begin{array}{l}0.0048^{* * *} \\
{[3.85]}\end{array}$ & $\begin{array}{l}0.0083^{* * *} \\
{[3.12]}\end{array}$ & $\begin{array}{l}0.0046^{* * *} \\
{[2.01]}\end{array}$ & $\begin{array}{l}0.0012^{* * *} \\
{[3.68]}\end{array}$ \\
\hline Volatility & $\begin{array}{l}0.1661^{* * *} \\
{[1.92]}\end{array}$ & $\begin{array}{l}-0.0844 \\
{[-0.64]}\end{array}$ & $\begin{array}{l}0.4727^{* * *} \\
{[3.12]}\end{array}$ & $\begin{array}{l}-0.1042 \\
{[-0.89]}\end{array}$ \\
\hline Age & $\begin{array}{l}-0.0009 * * * \\
{[-13.11]}\end{array}$ & $\begin{array}{l}-0.0009 * * * \\
{[-6.32]}\end{array}$ & $\begin{array}{l}-0.0011^{* * *} \\
{[-10.07]}\end{array}$ & $\begin{array}{l}-0.0006^{* * *} \\
{[-10.64]}\end{array}$ \\
\hline Size & $\begin{array}{l}0.0016^{* * *} \\
{[2.41]}\end{array}$ & $\begin{array}{l}0.0072^{* * *} \\
{[4.81]}\end{array}$ & $\begin{array}{l}-0.0013 \\
{[-1.39]}\end{array}$ & $\begin{array}{l}0.0017^{* * *} \\
{[2.99]}\end{array}$ \\
\hline Expenses & $\begin{array}{l}0.2298 * \\
{[1.66]}\end{array}$ & $\begin{array}{l}1.6802^{* * *} \\
{[5.70]}\end{array}$ & $\begin{array}{l}-0.5158 * * * \\
{[-3.09]}\end{array}$ & $\begin{array}{l}0.1971^{* * *} \\
{[2.28]}\end{array}$ \\
\hline Total Fee & $\begin{array}{l}-0.0012 \\
{[-0.79]}\end{array}$ & $\begin{array}{l}-0.0013 \\
{[-0.62]}\end{array}$ & $\begin{array}{l}-0.0071^{* *} \\
{[-2.70]}\end{array}$ & $\begin{array}{l}0.0080^{* * *} \\
{[5.80]}\end{array}$ \\
\hline Lag Flow & $\begin{array}{l}0.1878^{* * * *} \\
{[9.78]}\end{array}$ & $\begin{array}{l}0.2390 * * * \\
{[5.06]}\end{array}$ & $\begin{array}{l}0.1507^{* *} \\
{[5.23]}\end{array}$ & $\begin{array}{l}0.1865^{* * *} \\
{[7.52]}\end{array}$ \\
\hline Adj. $\mathrm{R}^{2}$ & 0.18 & 0.22 & 0.17 & 0.16 \\
\hline
\end{tabular}




\begin{tabular}{|c|c|c|c|c|}
\hline \multicolumn{5}{|c|}{ Panel C: Equation (9) } \\
\hline & $1980-2004$ & $1980-86$ & 1987-97 & 1998-2004 \\
\hline Intercept & $\begin{array}{l}-0.0095^{* *} \\
{[-1.56]}\end{array}$ & $\begin{array}{l}-0.0352 * * * \\
{[-3.11]}\end{array}$ & $\begin{array}{l}0.0115 \\
{[1.26]}\end{array}$ & $\begin{array}{l}-0.0218^{* * *} \\
{[-2.15]}\end{array}$ \\
\hline Low & $\begin{array}{l}0.0986^{* * * *} \\
{[6.79]}\end{array}$ & $\begin{array}{l}0.0666 \\
{[1.85]}\end{array}$ & $\begin{array}{l}0.1342^{* * *} \\
{[6.15]}\end{array}$ & $\begin{array}{l}0.0821^{* * *} \\
{[4.83]}\end{array}$ \\
\hline Low*Disp & $\begin{array}{l}-0.01079 * * \\
{[-4.40]}\end{array}$ & $\begin{array}{l}-0.2277 * * * \\
{[-3.93]}\end{array}$ & $\begin{array}{l}-0.1136 * * * \\
{[-3.17]}\end{array}$ & $\begin{array}{l}-0.0034 \\
{[-0.11]}\end{array}$ \\
\hline Mid & $\begin{array}{l}0.0353^{* * *} \\
{[8.19]}\end{array}$ & $\begin{array}{l}0.0194 * * * \\
{[2.24]}\end{array}$ & $\begin{array}{l}0.0349 * * * \\
{[6.11]}\end{array}$ & $\begin{array}{l}0.0519 * * * \\
{[5.97]}\end{array}$ \\
\hline Mid*Disp & $\begin{array}{l}0.0038 \\
{[0.24]}\end{array}$ & $\begin{array}{l}0.0587 \\
{[1.53]}\end{array}$ & $\begin{array}{l}-0.0119 \\
{[-0.48]}\end{array}$ & $\begin{array}{l}-0.0198 \\
{[-1.07]}\end{array}$ \\
\hline High & $\begin{array}{l}0.1763^{* * *} \\
{[9.34]}\end{array}$ & $\begin{array}{l}0.1025^{* * *} \\
{[2.68]}\end{array}$ & $\begin{array}{l}0.2169 * * * \\
{[6.77]}\end{array}$ & $\begin{array}{l}0.1783^{* * *} \\
{[7.45]}\end{array}$ \\
\hline High*Disp & $\begin{array}{l}-0.0715 \\
{[-0.98]}\end{array}$ & $\begin{array}{l}0.0386 \\
{[0.31]}\end{array}$ & $\begin{array}{l}-0.1558 \\
{[-1.14]}\end{array}$ & $\begin{array}{l}-0.0569 \\
{[-0.66]}\end{array}$ \\
\hline Category Flow & $\begin{array}{l}0.0050 * * * \\
{[4.26]}\end{array}$ & $\begin{array}{l}0.0100 * * * \\
{[3.53]}\end{array}$ & $\begin{array}{l}0.0042 * * * \\
{[2.06]}\end{array}$ & $\begin{array}{l}0.0013^{* * *} \\
{[3.77]}\end{array}$ \\
\hline Volatility & $\begin{array}{l}0.02140 \\
{[0.26]}\end{array}$ & $\begin{array}{l}-0.1438 \\
{[-0.86]}\end{array}$ & $\begin{array}{l}0.2842^{* *} \\
{[1.80]}\end{array}$ & $\begin{array}{l}-0.2588^{*} \\
{[-1.71]}\end{array}$ \\
\hline Age & $\begin{array}{l}-0.0009 * * * \\
{[-13.17]}\end{array}$ & $\begin{array}{l}-0.0009 * * * \\
{[-6.48]}\end{array}$ & $\begin{array}{l}-0.0011 * * * \\
{[-10.11]}\end{array}$ & $\begin{array}{l}-0.0006 * * * \\
{[-9.37]}\end{array}$ \\
\hline Size & $\begin{array}{l}0.0011 * \\
{[1.57]}\end{array}$ & $\begin{array}{l}0.0069 * * * \\
{[4.78]}\end{array}$ & $\begin{array}{l}-0.0020 * * * \\
{[-2.07]}\end{array}$ & $\begin{array}{l}0.0009 \\
{[1.55]}\end{array}$ \\
\hline Expenses & $\begin{array}{l}0.2945 * * * \\
{[2.09]}\end{array}$ & $\begin{array}{l}1.7257 * * * \\
{[5.55]}\end{array}$ & $\begin{array}{l}-0.3401 * \\
{[-1.89]}\end{array}$ & $\begin{array}{l}0.1409 * \\
{[1.90]}\end{array}$ \\
\hline Total Fee & $\begin{array}{l}-0.0008 \\
{[-0.52]}\end{array}$ & $\begin{array}{l}-0.0013 \\
{[-0.59]}\end{array}$ & $\begin{array}{l}-0.0067 * * \\
{[-2.39]}\end{array}$ & $\begin{array}{l}0.0088^{* * *} \\
{[6.86]}\end{array}$ \\
\hline Lag Flow & $\begin{array}{l}0.1810^{* * *} \\
{[9.68]}\end{array}$ & $\begin{array}{l}0.2306^{* * *} \\
{[4.91]}\end{array}$ & $\begin{array}{l}0.1484 * * \\
{[5.25]}\end{array}$ & $\begin{array}{l}0.1767 * * * \\
{[7.62]}\end{array}$ \\
\hline Adj. $\mathrm{R}^{2}$ & 0.21 & 0.23 & 0.20 & 0.20 \\
\hline
\end{tabular}




\section{Table 9: Tax Overhang and Fund Flows}

This table compares the level of fund flows between funds with high and low tax overhang. Every quarter and within each investment category, funds are first sorted into deciles based on their returns in the previous quarter. Funds in the same performance decile are further sorted into quintiles based on their tax overhangs over the performance measurement period. Funds in the top quintile have the highest overhang (High), and funds in the bottom quintile have the lowest overhang (Low). In the quarter immediately after the portfolio formation period, portfolio flows are calculated by equally weighting flows to the funds included in the portfolio. Fund flow is calculated as $F L_{i, t}=\frac{T N A_{i, t}-T N A_{i, t-1}\left(1+r_{i, t}\right)}{T N A}$, where $T N A_{i, t}$ is the total net assets of fund $i$ at the end of quarter $t$, and $r_{i, t}$ is the total return of fund $i$ in quarter $t$. The time-series means and medians of the portfolio flows are reported in Panel B. We also compare fund flows on an aggregate level. Funds in the bottom 2 return deciles are grouped into Low performance group (Low), funds in the middle 6 deciles are grouped into Medium performance group (Med), and funds in the top 2 deciles are grouped into High performance group (High). Within each return group, funds with the highest overhang (High) and lowest overhang (Low) are further grouped into portfolios. Portfolio flows are calculated by equally weighting fund flows. The time-series means and medians of portfolio flows by return groups are reported in Panel A. The portfolio analysis is performed over the whole sample period of 1980-2004, and also for three sub-sample periods divided based on the capital gains tax rate changes. T-statistics for means and p-values for medians are reported in brackets. 


\begin{tabular}{|c|c|c|c|c|c|c|c|c|c|}
\hline \multirow[t]{2}{*}{ Return } & \multirow{2}{*}{$\begin{array}{l}\text { Tax } \\
\text { Overhang }\end{array}$} & \multicolumn{2}{|c|}{$1980-2004$} & \multicolumn{2}{|c|}{$1980-86$} & \multicolumn{2}{|c|}{$1987-97$} & \multicolumn{2}{|c|}{ 1998-2004 } \\
\hline & & Mean & Median & Mean & Median & Mean & Median & Mean & Median \\
\hline & & & & Panel & eturn Grou & & & & \\
\hline \multirow[t]{3}{*}{ Low } & Low & $\begin{array}{c}-0.13 \\
{[-0.52]}\end{array}$ & $\begin{array}{c}-2.38 \\
{[<.0001]}\end{array}$ & $\begin{array}{c}0.06 \\
{[0.08]}\end{array}$ & $\begin{array}{c}-2.07 \\
{[<.0001]}\end{array}$ & $\begin{array}{c}2.67 \\
{[6.03]}\end{array}$ & $\begin{array}{c}-0.87 \\
{[0.0053]}\end{array}$ & $\begin{array}{c}-2.49 \\
{[-8.53]}\end{array}$ & $\begin{array}{c}-3.68 \\
{[<.0001]}\end{array}$ \\
\hline & High & $\begin{array}{c}-1.21 \\
{[-6.63]}\end{array}$ & $\begin{array}{c}-2.02 \\
{[<.0001]}\end{array}$ & $\begin{array}{c}0.06 \\
{[0.11]}\end{array}$ & $\begin{array}{c}-1.58 \\
{[<.0001]}\end{array}$ & $\begin{array}{c}0.19 \\
{[0.55]}\end{array}$ & $\begin{array}{c}-1.46 \\
{[<.0001]}\end{array}$ & $\begin{array}{c}-2.53 \\
{[-12.91]}\end{array}$ & $\begin{array}{c}-2.59 \\
{[<.0001]}\end{array}$ \\
\hline & Difference & $\begin{array}{c}1.08 \\
{[3.49]}\end{array}$ & $\begin{array}{c}-0.36 \\
{[0.2082]}\end{array}$ & $\begin{array}{c}0.00 \\
{[-0.00]}\end{array}$ & $\begin{array}{c}-0.49 \\
{[0.1028]}\end{array}$ & $\begin{array}{c}2.48 \\
{[4.43]}\end{array}$ & $\begin{array}{c}0.59 \\
{[0.0043]}\end{array}$ & $\begin{array}{c}0.05 \\
{[0.13]}\end{array}$ & $\begin{array}{c}-1.09 \\
{[0.0012]}\end{array}$ \\
\hline \multirow[t]{3}{*}{ Med } & Low & $\begin{array}{c}3.05 \\
{[18.64]}\end{array}$ & $\begin{array}{c}-0.62 \\
{[<.0001]}\end{array}$ & $\begin{array}{c}1.30 \\
{[3.07]}\end{array}$ & $\begin{array}{c}-1.13 \\
{[0.0002]}\end{array}$ & $\begin{array}{c}7.05 \\
{[23.72]}\end{array}$ & $\begin{array}{c}2.09 \\
{[<.0001]}\end{array}$ & $\begin{array}{c}-0.10 \\
{[-0.56]}\end{array}$ & $\begin{array}{c}-1.99 \\
{[<.0001]}\end{array}$ \\
\hline & High & $\begin{array}{c}0.64 \\
{[5.72]}\end{array}$ & $\begin{array}{c}-1.02 \\
{[<.0001]}\end{array}$ & $\begin{array}{c}-0.35 \\
{[-0.99]}\end{array}$ & $\begin{array}{c}-1.65 \\
{[<.0001]}\end{array}$ & $\begin{array}{c}1.74 \\
{[8.67]}\end{array}$ & $\begin{array}{c}-0.69 \\
{[<.0001]}\end{array}$ & $\begin{array}{c}-0.15 \\
{[-1.14]}\end{array}$ & $\begin{array}{c}-1.28 \\
{[<.0001]}\end{array}$ \\
\hline & Difference & $\begin{array}{c}2.41 \\
{[12.12]}\end{array}$ & $\begin{array}{c}0.40 \\
{[<.0001]}\end{array}$ & $\begin{array}{c}1.65 \\
{[2.99]}\end{array}$ & $\begin{array}{c}0.52 \\
{[0.0048]}\end{array}$ & $\begin{array}{c}5.32 \\
{[14.82]}\end{array}$ & $\begin{array}{c}2.78 \\
{[<.0001]}\end{array}$ & $\begin{array}{c}0.05 \\
{[0.25]}\end{array}$ & $\begin{array}{c}0.71 \\
{[<.0001]}\end{array}$ \\
\hline \multirow[t]{3}{*}{ High } & Low & $\begin{array}{c}8.51 \\
{[20.84]}\end{array}$ & $\begin{array}{c}1.80 \\
{[<.0001]}\end{array}$ & $\begin{array}{c}4.85 \\
{[4.74]}\end{array}$ & $\begin{array}{c}0.70 \\
{[0.4278]}\end{array}$ & $\begin{array}{c}14.52 \\
{[19.22]}\end{array}$ & $\begin{array}{c}6.04 \\
{[<.0001]}\end{array}$ & $\begin{array}{c}3.93 \\
{[9.18]}\end{array}$ & $\begin{array}{c}-0.32 \\
{[0.2005]}\end{array}$ \\
\hline & High & $\begin{array}{c}3.24 \\
{[14.88]}\end{array}$ & $\begin{array}{c}0.38 \\
{[0.0012]}\end{array}$ & $\begin{array}{c}1.55 \\
{[2.39]}\end{array}$ & $\begin{array}{c}-0.56 \\
{[0.0389]}\end{array}$ & $\begin{array}{c}3.73 \\
{[10.63]}\end{array}$ & $\begin{array}{c}0.61 \\
{[0.0021]}\end{array}$ & $\begin{array}{c}3.04 \\
{[10.18]}\end{array}$ & $\begin{array}{c}0.36 \\
{[0.0133]}\end{array}$ \\
\hline & Difference & $\begin{array}{c}5.27 \\
{[11.40]}\end{array}$ & $\begin{array}{c}1.42 \\
{[<.0001]}\end{array}$ & $\begin{array}{c}3.30 \\
{[2.72]}\end{array}$ & $\begin{array}{c}1.26 \\
{[0.0066]}\end{array}$ & $\begin{array}{c}10.79 \\
{[12.95]}\end{array}$ & $\begin{array}{c}5.43 \\
{[<.0001]}\end{array}$ & $\begin{array}{c}0.88 \\
{[1.69]}\end{array}$ & $\begin{array}{c}-0.68 \\
{[0.0046]}\end{array}$ \\
\hline
\end{tabular}




\begin{tabular}{|c|c|c|c|c|c|c|c|c|c|}
\hline \multirow[t]{2}{*}{ Return } & \multirow{2}{*}{$\begin{array}{l}\text { Tax } \\
\text { Overhang }\end{array}$} & \multicolumn{2}{|c|}{$1980-2004$} & \multicolumn{2}{|c|}{ 1980-86 } & \multicolumn{2}{|c|}{ 1987-97 } & \multicolumn{2}{|c|}{ 1998-2004 } \\
\hline & & Mean & Median & Mean & Median & Mean & Median & Mean & Median \\
\hline & & & & Panel B & turn Decile & & & & \\
\hline \multirow[t]{3}{*}{1} & Low & $\begin{array}{c}-1.41 \\
{[-4.33]}\end{array}$ & $\begin{array}{c}-3.15 \\
{[<.0001]}\end{array}$ & $\begin{array}{c}-0.34 \\
{[-0.34]}\end{array}$ & $\begin{array}{c}-2.44 \\
{[0.0049]}\end{array}$ & $\begin{array}{c}0.84 \\
{[1.56]}\end{array}$ & $\begin{array}{c}-1.86 \\
{[<.0001]}\end{array}$ & $\begin{array}{c}-3.40 \\
{[-8.08]}\end{array}$ & $\begin{array}{c}-4.03 \\
{[<.0001]}\end{array}$ \\
\hline & High & $\begin{array}{c}-1.48 \\
{[-6.13]}\end{array}$ & $\begin{array}{c}-2.10 \\
{[<.0001]}\end{array}$ & $\begin{array}{c}0.37 \\
{[0.46]}\end{array}$ & $\begin{array}{c}-1.21 \\
{[0.0533]}\end{array}$ & $\begin{array}{c}-0.09 \\
{[-0.20]}\end{array}$ & $\begin{array}{c}-1.54 \\
{[<.0001]}\end{array}$ & $\begin{array}{c}-2.84 \\
{[-10.71]}\end{array}$ & $\begin{array}{c}-2.67 \\
{[<.0001]}\end{array}$ \\
\hline & Difference & $\begin{array}{c}0.07 \\
{[0.16]}\end{array}$ & $\begin{array}{c}-1.05 \\
{[0.0007]}\end{array}$ & $\begin{array}{c}-0.71 \\
{[-0.55]}\end{array}$ & $\begin{array}{c}-1.23 \\
{[0.0379]}\end{array}$ & $\begin{array}{c}0.93 \\
{[1.33]}\end{array}$ & $\begin{array}{c}-0.32 \\
{[0.2725]}\end{array}$ & $\begin{array}{c}-0.56 \\
{[-1.13]}\end{array}$ & $\begin{array}{c}-1.36 \\
{[0.0002]}\end{array}$ \\
\hline \multirow[t]{3}{*}{2} & Low & $\begin{array}{c}1.12 \\
{[2.98]}\end{array}$ & $\begin{array}{c}-1.73 \\
{[<.0001]}\end{array}$ & $\begin{array}{c}0.41 \\
{[0.36]}\end{array}$ & $\begin{array}{c}-1.75 \\
{[0.0000]}\end{array}$ & $\begin{array}{c}4.43 \\
{[6.43]}\end{array}$ & $\begin{array}{c}0.24 \\
{[0.5984]}\end{array}$ & $\begin{array}{c}-1.59 \\
{[-3.96]}\end{array}$ & $\begin{array}{c}-3.23 \\
{[<.0001]}\end{array}$ \\
\hline & High & $\begin{array}{c}-0.95 \\
{[-3.48]}\end{array}$ & $\begin{array}{c}-1.98 \\
{[<.0001]}\end{array}$ & $\begin{array}{c}-0.21 \\
{[-0.27]}\end{array}$ & $\begin{array}{c}-2.45 \\
{[<.0001]}\end{array}$ & $\begin{array}{c}0.46 \\
{[0.89]}\end{array}$ & $\begin{array}{c}-1.45 \\
{[<.0001]}\end{array}$ & $\begin{array}{c}-2.24 \\
{[-7.73]}\end{array}$ & $\begin{array}{c}-2.47 \\
{[<.0001]}\end{array}$ \\
\hline & Difference & $\begin{array}{c}2.07 \\
{[4.46]}\end{array}$ & $\begin{array}{c}0.25 \\
{[0.0199]}\end{array}$ & $\begin{array}{c}0.63 \\
{[0.45]}\end{array}$ & $\begin{array}{c}0.70 \\
{[0.4072]}\end{array}$ & $\begin{array}{c}3.98 \\
{[4.61]}\end{array}$ & $\begin{array}{c}1.69 \\
{[<.0001]}\end{array}$ & $\begin{array}{c}0.64 \\
{[1.30]}\end{array}$ & $\begin{array}{c}-0.76 \\
{[0.1987]}\end{array}$ \\
\hline \multirow[t]{3}{*}{3} & Low & $\begin{array}{c}1.94 \\
{[5.07]}\end{array}$ & $\begin{array}{c}-1.21 \\
{[<.0001]}\end{array}$ & $\begin{array}{c}0.20 \\
{[0.25]}\end{array}$ & $\begin{array}{c}-1.38 \\
{[0.0604]}\end{array}$ & $\begin{array}{c}5.71 \\
{[8.26]}\end{array}$ & $\begin{array}{c}1.26 \\
{[0.0041]}\end{array}$ & $\begin{array}{c}-1.00 \\
{[-2.32]}\end{array}$ & $\begin{array}{c}-2.74 \\
{[<.0001]}\end{array}$ \\
\hline & High & $\begin{array}{c}-0.48 \\
{[-1.97]}\end{array}$ & $\begin{array}{c}-1.60 \\
{[<.0001]}\end{array}$ & $\begin{array}{c}-0.84 \\
{[-1.13]}\end{array}$ & $\begin{array}{c}-1.94 \\
{[0.0000]}\end{array}$ & $\begin{array}{c}1.02 \\
{[2.30]}\end{array}$ & $\begin{array}{c}-1.04 \\
{[<.0001]}\end{array}$ & $\begin{array}{c}-1.69 \\
{[-6.19]}\end{array}$ & $\begin{array}{c}-2.13 \\
{[<.0001]}\end{array}$ \\
\hline & Difference & $\begin{array}{c}2.42 \\
{[5.34]}\end{array}$ & $\begin{array}{c}0.39 \\
{[0.0147]}\end{array}$ & $\begin{array}{c}1.04 \\
{[0.94]}\end{array}$ & $\begin{array}{c}0.56 \\
{[0.1957]}\end{array}$ & $\begin{array}{c}4.69 \\
{[5.71]}\end{array}$ & $\begin{array}{c}2.30 \\
{[<.0001]}\end{array}$ & $\begin{array}{c}0.69 \\
{[1.35]}\end{array}$ & $\begin{array}{c}0.39 \\
{[0.0469]}\end{array}$ \\
\hline
\end{tabular}




\begin{tabular}{|c|c|c|c|c|c|c|c|c|c|}
\hline \multirow[t]{3}{*}{4} & Low & $\begin{array}{c}2.25 \\
{[5.83]}\end{array}$ & $\begin{array}{c}-0.97 \\
{[<.0001]}\end{array}$ & $\begin{array}{c}0.19 \\
{[0.21]}\end{array}$ & $\begin{array}{c}-1.98 \\
{[0.0015]}\end{array}$ & $\begin{array}{c}6.39 \\
{[9.25]}\end{array}$ & $\begin{array}{c}2.54 \\
{[<.0001]}\end{array}$ & $\begin{array}{c}-0.98 \\
{[-2.29]}\end{array}$ & $\begin{array}{c}-2.60 \\
{[<.0001]}\end{array}$ \\
\hline & High & $\begin{array}{c}0.14 \\
{[0.52]}\end{array}$ & $\begin{array}{c}-1.14 \\
{[<.0001]}\end{array}$ & $\begin{array}{c}-0.03 \\
{[-0.04]}\end{array}$ & $\begin{array}{c}-1.79 \\
{[0.0001]}\end{array}$ & $\begin{array}{c}1.71 \\
{[3.24]}\end{array}$ & $\begin{array}{c}-0.75 \\
{[0.0001]}\end{array}$ & $\begin{array}{c}-1.17 \\
{[-4.44]}\end{array}$ & $\begin{array}{c}-1.65 \\
{[<.0001]}\end{array}$ \\
\hline & Difference & $\begin{array}{c}2.11 \\
{[4.48]}\end{array}$ & $\begin{array}{c}0.17 \\
{[0.0443]}\end{array}$ & $\begin{array}{c}0.23 \\
{[0.19]}\end{array}$ & $\begin{array}{c}-0.19 \\
{[0.3614]}\end{array}$ & $\begin{array}{c}4.68 \\
{[5.37]}\end{array}$ & $\begin{array}{c}3.29 \\
{[<.0001]}\end{array}$ & $\begin{array}{c}0.18 \\
{[0.36]}\end{array}$ & $\begin{array}{c}0.95 \\
{[0.0027]}\end{array}$ \\
\hline \multirow[t]{3}{*}{5} & Low & $\begin{array}{c}2.51 \\
{[6.48]}\end{array}$ & $\begin{array}{c}-0.73 \\
{[0.0001]}\end{array}$ & $\begin{array}{c}2.13 \\
{[1.74]}\end{array}$ & $\begin{array}{c}-0.53 \\
{[0.5764]}\end{array}$ & $\begin{array}{c}6.44 \\
{[8.99]}\end{array}$ & $\begin{array}{c}1.59 \\
{[<.0001]}\end{array}$ & $\begin{array}{c}-0.75 \\
{[-1.90]}\end{array}$ & $\begin{array}{c}-2.50 \\
{[<.0001]}\end{array}$ \\
\hline & High & $\begin{array}{c}0.38 \\
{[1.38]}\end{array}$ & $\begin{array}{c}-1.14 \\
{[<.0001]}\end{array}$ & $\begin{array}{c}-0.79 \\
{[-1.60]}\end{array}$ & $\begin{array}{c}-1.71 \\
{[0.0000]}\end{array}$ & $\begin{array}{c}1.35 \\
{[2.70]}\end{array}$ & $\begin{array}{c}-0.64 \\
{[0.0000]}\end{array}$ & $\begin{array}{c}-0.29 \\
{[-0.87]}\end{array}$ & $\begin{array}{c}-1.52 \\
{[<.0001]}\end{array}$ \\
\hline & Difference & $\begin{array}{c}2.13 \\
{[4.49]}\end{array}$ & $\begin{array}{c}0.41 \\
{[0.0497]}\end{array}$ & $\begin{array}{c}2.91 \\
{[2.21]}\end{array}$ & $\begin{array}{c}1.18 \\
{[0.0512]}\end{array}$ & $\begin{array}{c}5.09 \\
{[5.82]}\end{array}$ & $\begin{array}{c}2.23 \\
{[<.0001]}\end{array}$ & $\begin{array}{c}-0.46 \\
{[-0.89]}\end{array}$ & $\begin{array}{c}-0.98 \\
{[0.0003]}\end{array}$ \\
\hline \multirow[t]{3}{*}{6} & Low & $\begin{array}{c}3.18 \\
{[8.04]}\end{array}$ & $\begin{array}{c}-0.21 \\
{[0.1844]}\end{array}$ & $\begin{array}{c}2.38 \\
{[2.25]}\end{array}$ & $\begin{array}{c}-0.07 \\
{[0.9088]}\end{array}$ & $\begin{array}{c}6.97 \\
{[9.73]}\end{array}$ & $\begin{array}{c}2.08 \\
{[<.0001]}\end{array}$ & $\begin{array}{c}0.09 \\
{[0.21]}\end{array}$ & $\begin{array}{c}-1.84 \\
{[<.0001]}\end{array}$ \\
\hline & High & $\begin{array}{c}1.24 \\
{[4.43]}\end{array}$ & $\begin{array}{c}-0.72 \\
{[<.0001]}\end{array}$ & $\begin{array}{c}0.69 \\
{[0.55]}\end{array}$ & $\begin{array}{c}-1.01 \\
{[0.1354]}\end{array}$ & $\begin{array}{c}1.99 \\
{[4.31]}\end{array}$ & $\begin{array}{c}-0.61 \\
{[0.0003]}\end{array}$ & $\begin{array}{c}0.67 \\
{[1.90]}\end{array}$ & $\begin{array}{c}-0.84 \\
{[<.0001]}\end{array}$ \\
\hline & Difference & $\begin{array}{c}1.94 \\
{[4.01]}\end{array}$ & $\begin{array}{c}0.51 \\
{[0.0473]}\end{array}$ & $\begin{array}{c}1.68 \\
{[1.02]}\end{array}$ & $\begin{array}{c}0.94 \\
{[0.0523]}\end{array}$ & $\begin{array}{c}4.98 \\
{[5.84]}\end{array}$ & $\begin{array}{c}2.69 \\
{[<.0001]}\end{array}$ & $\begin{array}{c}-0.58 \\
{[-1.03]}\end{array}$ & $\begin{array}{c}-1.00 \\
{[0.0005]}\end{array}$ \\
\hline \multirow[t]{3}{*}{7} & Low & $\begin{array}{c}3.45 \\
{[8.54]}\end{array}$ & $\begin{array}{c}-0.54 \\
{[0.0606]}\end{array}$ & $\begin{array}{c}1.25 \\
{[1.53]}\end{array}$ & $\begin{array}{c}-0.85 \\
{[0.2480]}\end{array}$ & $\begin{array}{c}7.00 \\
{[9.72]}\end{array}$ & $\begin{array}{c}2.18 \\
{[<.0001]}\end{array}$ & $\begin{array}{c}0.73 \\
{[1.56]}\end{array}$ & $\begin{array}{c}-1.68 \\
{[<.0001]}\end{array}$ \\
\hline & High & $\begin{array}{c}0.53 \\
{[2.18]}\end{array}$ & $\begin{array}{c}-0.97 \\
{[<.0001]}\end{array}$ & $\begin{array}{c}-1.02 \\
{[-2.01]}\end{array}$ & $\begin{array}{c}-1.62 \\
{[0.0002]}\end{array}$ & $\begin{array}{c}1.46 \\
{[3.36]}\end{array}$ & $\begin{array}{c}-0.78 \\
{[0.0001]}\end{array}$ & $\begin{array}{c}-0.07 \\
{[-0.22]}\end{array}$ & $\begin{array}{c}-1.03 \\
{[<.0001]}\end{array}$ \\
\hline & Difference & $\begin{array}{c}2.92 \\
{[6.21]}\end{array}$ & $\begin{array}{c}0.43 \\
{[0.0010]}\end{array}$ & $\begin{array}{c}2.28 \\
{[2.36]}\end{array}$ & $\begin{array}{c}0.77 \\
{[0.0342]}\end{array}$ & $\begin{array}{c}5.54 \\
{[6.59]}\end{array}$ & $\begin{array}{c}2.96 \\
{[<.0001]}\end{array}$ & $\begin{array}{c}0.80 \\
{[1.44]}\end{array}$ & $\begin{array}{c}-0.65 \\
{[0.0423]}\end{array}$ \\
\hline
\end{tabular}




\begin{tabular}{|c|c|c|c|c|c|c|c|c|c|}
\hline \multirow[t]{3}{*}{8} & Low & $\begin{array}{c}4.97 \\
{[11.28]}\end{array}$ & $\begin{array}{c}0.37 \\
{[0.0696]}\end{array}$ & $\begin{array}{c}1.58 \\
{[1.26]}\end{array}$ & $\begin{array}{c}-1.31 \\
{[0.0675]}\end{array}$ & $\begin{array}{c}9.82 \\
{[12.00]}\end{array}$ & $\begin{array}{c}3.78 \\
{[<.0001]}\end{array}$ & $\begin{array}{c}1.32 \\
{[2.96]}\end{array}$ & $\begin{array}{c}-0.97 \\
{[0.0021]}\end{array}$ \\
\hline & High & $\begin{array}{c}2.05 \\
{[6.23]}\end{array}$ & $\begin{array}{c}-0.55 \\
{[0.0007]}\end{array}$ & $\begin{array}{c}-0.14 \\
{[-0.12]}\end{array}$ & $\begin{array}{c}-1.56 \\
{[0.0002]}\end{array}$ & $\begin{array}{c}2.90 \\
{[5.16]}\end{array}$ & $\begin{array}{c}-0.20 \\
{[0.1723]}\end{array}$ & $\begin{array}{c}1.62 \\
{[3.87]}\end{array}$ & $\begin{array}{c}-0.55 \\
{[0.0356]}\end{array}$ \\
\hline & Difference & $\begin{array}{c}2.92 \\
{[5.30]}\end{array}$ & $\begin{array}{c}0.92 \\
{[0.0005]}\end{array}$ & $\begin{array}{c}1.71 \\
{[1.01]}\end{array}$ & $\begin{array}{c}0.25 \\
{[0.2485]}\end{array}$ & $\begin{array}{c}6.92 \\
{[6.97]}\end{array}$ & $\begin{array}{c}3.98 \\
{[<.0001]}\end{array}$ & $\begin{array}{c}-0.30 \\
{[-0.49]}\end{array}$ & $\begin{array}{c}-0.42 \\
{[0.0314]}\end{array}$ \\
\hline \multirow[t]{3}{*}{9} & Low & $\begin{array}{c}6.63 \\
{[12.75]}\end{array}$ & $\begin{array}{c}1.05 \\
{[0.0001]}\end{array}$ & $\begin{array}{c}3.85 \\
{[3.07]}\end{array}$ & $\begin{array}{c}-0.08 \\
{[1.0000]}\end{array}$ & $\begin{array}{c}11.85 \\
{[12.22]}\end{array}$ & $\begin{array}{c}4.61 \\
{[<.0001]}\end{array}$ & $\begin{array}{c}2.59 \\
{[4.80]}\end{array}$ & $\begin{array}{c}-0.85 \\
{[0.0097]}\end{array}$ \\
\hline & High & $\begin{array}{c}2.53 \\
{[8.60]}\end{array}$ & $\begin{array}{c}0.15 \\
{[0.3127]}\end{array}$ & $\begin{array}{c}1.57 \\
{[1.70]}\end{array}$ & $\begin{array}{c}-0.24 \\
{[0.4160]}\end{array}$ & $\begin{array}{c}3.39 \\
{[6.56]}\end{array}$ & $\begin{array}{c}0.55 \\
{[0.0939]}\end{array}$ & $\begin{array}{c}1.92 \\
{[5.32]}\end{array}$ & $\begin{array}{c}0.03 \\
{[0.8717]}\end{array}$ \\
\hline & Difference & $\begin{array}{c}4.11 \\
{[6.87]}\end{array}$ & $\begin{array}{c}0.90 \\
{[0.0003]}\end{array}$ & $\begin{array}{c}2.28 \\
{[1.46]}\end{array}$ & $\begin{array}{c}0.16 \\
{[0.1095]}\end{array}$ & $\begin{array}{c}8.47 \\
{[7.71]}\end{array}$ & $\begin{array}{c}4.06 \\
{[<.0001]}\end{array}$ & $\begin{array}{c}0.67 \\
{[1.03]}\end{array}$ & $\begin{array}{c}-0.88 \\
{[0.0127]}\end{array}$ \\
\hline \multirow[t]{3}{*}{10} & Low & $\begin{array}{c}10.34 \\
{[16.61]}\end{array}$ & $\begin{array}{c}2.73 \\
{[<.0001]}\end{array}$ & $\begin{array}{c}5.72 \\
{[3.64]}\end{array}$ & $\begin{array}{c}1.18 \\
{[0.2780]}\end{array}$ & $\begin{array}{c}17.14 \\
{[14.97]}\end{array}$ & $\begin{array}{c}8.54 \\
{[<.0001]}\end{array}$ & $\begin{array}{c}5.25 \\
{[7.96]}\end{array}$ & $\begin{array}{c}0.31 \\
{[0.4708]}\end{array}$ \\
\hline & High & $\begin{array}{c}3.93 \\
{[12.31]}\end{array}$ & $\begin{array}{c}0.75 \\
{[0.0004]}\end{array}$ & $\begin{array}{c}1.53 \\
{[1.67]}\end{array}$ & $\begin{array}{c}-0.93 \\
{[0.0503]}\end{array}$ & $\begin{array}{c}4.07 \\
{[8.53]}\end{array}$ & $\begin{array}{c}0.79 \\
{[0.0088]}\end{array}$ & $\begin{array}{c}4.15 \\
{[8.80]}\end{array}$ & $\begin{array}{c}0.98 \\
{[0.0010]}\end{array}$ \\
\hline & Difference & $\begin{array}{c}6.41 \\
{[9.16]}\end{array}$ & $\begin{array}{c}1.98 \\
{[<.0001]}\end{array}$ & $\begin{array}{c}4.19 \\
{[2.30]}\end{array}$ & $\begin{array}{c}2.11 \\
{[0.0131]}\end{array}$ & $\begin{array}{c}13.08 \\
{[10.54]}\end{array}$ & $\begin{array}{c}7.75 \\
{[<.0001]}\end{array}$ & $\begin{array}{c}1.10 \\
{[1.36]}\end{array}$ & $\begin{array}{c}-0.67 \\
{[0.0717]}\end{array}$ \\
\hline
\end{tabular}




\section{Table 10: Tax Overhang, Disposition Effect and Fund Flows}

This table compares the level of fund flows between funds exhibiting strong disposition effects and funds without such behavior controlling for tax overhang. Every quarter and within each investment category, funds are first sorted into deciles based on their tax overhangs in the previous quarter. Funds in the same overhang decile are further sorted into quintiles based on their average disposition spreads over the overhang measurement period. Funds in the top quintile have the highest disposition spread (Disp), and funds in the bottom quintile have the lowest disposition spread (Nondisp). In the quarter immediately after the portfolio formation period, portfolio flows are calculated by equally weighting flows to the funds included in the ortfolio. Fund flow is calculated as $F L_{i, t}=\frac{T N A_{i, t}-T N A_{i, t-1}\left(1+r_{i, t}\right)}{T N A_{i, t-1}}$, where $T N A_{i, t}$ is the total net assets of fund $i$ at the end of quarter $t$, and $r_{i, t}$ is the total return of fund $i$ in quarter $t$. The time-series means and medians of the portfolio flows are reported in Panel B. We also compare fund flows on an aggregate level. Funds in the bottom 2 overhang deciles are grouped into Low overhang group (Low), funds in the middle 6 deciles are grouped into Medium overhang group (Med), and funds in the top 2 deciles are grouped into High overhang group (High). Within each overhang group, funds with the highest disposition spread (Disp) and lowest disposition spread (Nondisp) are further grouped into portfolios. Portfolio flows are calculated by equally weighting fund flows. The time-series means and medians of portfolio flows by overhang groups are reported in Panel A. The portfolio analysis is performed over the whole sample period of 1980-2004, and also for three sub-sample periods divided based on the capital gains tax rate changes. T-statistics for means and p-values for medians are reported in brackets. 


\begin{tabular}{|c|c|c|c|c|c|c|c|c|c|}
\hline \multirow{2}{*}{$\begin{array}{l}\text { Tax } \\
\text { overhang }\end{array}$} & \multirow{2}{*}{$\begin{array}{l}\text { Disposition } \\
\text { Effect }\end{array}$} & \multicolumn{2}{|c|}{$1980-2004$} & \multicolumn{2}{|c|}{$1980-86$} & \multicolumn{2}{|c|}{ 1987-97 } & \multicolumn{2}{|c|}{ 1998-2004 } \\
\hline & & Mean & Median & Mean & Median & Mean & Median & Mean & Median \\
\hline \multicolumn{10}{|c|}{ Panel A: Tax Overhang Groups } \\
\hline \multirow[t]{3}{*}{ Low } & Nondisp & $\begin{array}{c}3.22 \\
{[9.89]}\end{array}$ & $\begin{array}{c}-0.83 \\
{[<.0001]}\end{array}$ & $\begin{array}{l}3.09 \\
4.11]\end{array}$ & $\begin{array}{c}-0.16 \\
{[0.7800]}\end{array}$ & $\begin{array}{c}7.55 \\
{[11.45]}\end{array}$ & $\begin{array}{c}1.54 \\
{[<.0001]}\end{array}$ & $\begin{array}{c}-0.09 \\
{[-0.29]}\end{array}$ & $\begin{array}{c}-2.33 \\
{[<.0001]}\end{array}$ \\
\hline & Disp & $\begin{array}{c}0.79 \\
{[3.03]}\end{array}$ & $\begin{array}{c}-1.74 \\
{[<.0001]}\end{array}$ & $\begin{array}{c}0.07 \\
{[0.13]}\end{array}$ & $\begin{array}{c}-1.62 \\
{[<.0001]}\end{array}$ & $\begin{array}{c}4.83 \\
{[9.86]}\end{array}$ & $\begin{array}{c}0.36 \\
{[0.2563]}\end{array}$ & $\begin{array}{c}-2.41 \\
{[-8.17]}\end{array}$ & $\begin{array}{c}-3.33 \\
{[<.0001]}\end{array}$ \\
\hline & Difference & $\begin{array}{c}2.42 \\
{[5.81]}\end{array}$ & $\begin{array}{c}0.91 \\
{[<.0001]}\end{array}$ & $\begin{array}{c}3.02 \\
{[3.30]}\end{array}$ & $\begin{array}{c}1.46 \\
{[0.0002]}\end{array}$ & $\begin{array}{c}2.73 \\
{[3.35]}\end{array}$ & $\begin{array}{c}1.18 \\
{[0.0025]}\end{array}$ & $\begin{array}{c}2.32 \\
{[5.29]}\end{array}$ & $\begin{array}{c}1.00 \\
{[<.0001]}\end{array}$ \\
\hline \multirow[t]{3}{*}{ Med } & Nondisp & $\begin{array}{c}3.06 \\
{[22.49]}\end{array}$ & $\begin{array}{c}0.24 \\
{[0.0013]}\end{array}$ & $\begin{array}{c}2.09 \\
{[4.79]}\end{array}$ & $\begin{array}{c}0.01 \\
{[0.8620]}\end{array}$ & $\begin{array}{c}4.78 \\
{[19.81]}\end{array}$ & $\begin{array}{c}1.39 \\
{[<.0001]}\end{array}$ & $\begin{array}{c}1.75 \\
{[10.72]}\end{array}$ & $\begin{array}{c}-0.39 \\
{[0.0000]}\end{array}$ \\
\hline & Disp & $\begin{array}{c}1.57 \\
{[11.30]}\end{array}$ & $\begin{array}{c}-0.47 \\
{[<.0001]}\end{array}$ & $\begin{array}{c}1.53 \\
{[3.83]}\end{array}$ & $\begin{array}{c}-0.59 \\
{[0.0066]}\end{array}$ & $\begin{array}{c}2.63 \\
{[11.07]}\end{array}$ & $\begin{array}{c}-0.06 \\
{[0.5186]}\end{array}$ & $\begin{array}{c}0.62 \\
{[3.49]}\end{array}$ & $\begin{array}{c}-0.86 \\
{[<.0001]}\end{array}$ \\
\hline & Difference & $\begin{array}{c}1.49 \\
{[7.59]}\end{array}$ & $\begin{array}{c}0.71 \\
{[<.0001]}\end{array}$ & $\begin{array}{c}0.56 \\
{[0.95]}\end{array}$ & $\begin{array}{c}0.60 \\
{[0.1497]}\end{array}$ & $\begin{array}{c}2.14 \\
{[6.42]}\end{array}$ & $\begin{array}{c}1.45 \\
{[<.0001]}\end{array}$ & $\begin{array}{c}1.13 \\
{[4.63]}\end{array}$ & $\begin{array}{c}0.47 \\
{[<.0001]}\end{array}$ \\
\hline \multirow[t]{3}{*}{ High } & Nondisp & $\begin{array}{l}1.01 \\
{[5.11]}\end{array}$ & $\begin{array}{c}-0.79 \\
{[<.0001]}\end{array}$ & $\begin{array}{c}0.40 \\
{[0.59]}\end{array}$ & $\begin{array}{c}-1.52 \\
{[0.0001]}\end{array}$ & $\begin{array}{c}1.94 \\
{[5.49]}\end{array}$ & $\begin{array}{c}-0.47 \\
{[0.0011]}\end{array}$ & $\begin{array}{c}0.35 \\
{[1.46]}\end{array}$ & $\begin{array}{c}-0.96 \\
{[<.0001]}\end{array}$ \\
\hline & Disp & $\begin{array}{c}0.80 \\
{[3.86]}\end{array}$ & $\begin{array}{c}-0.90 \\
{[<.0001]}\end{array}$ & $\begin{array}{c}0.50 \\
{[0.88]}\end{array}$ & $\begin{array}{c}-0.50 \\
{[0.1634]}\end{array}$ & $\begin{array}{c}1.25 \\
{[3.61]}\end{array}$ & $\begin{array}{c}-0.94 \\
{[<.0001]}\end{array}$ & $\begin{array}{c}0.42 \\
{[1.54]}\end{array}$ & $\begin{array}{c}-0.91 \\
{[<.0001]}\end{array}$ \\
\hline & Difference & $\begin{array}{c}0.21 \\
{[0.70]}\end{array}$ & $\begin{array}{c}0.11 \\
{[0.3141]}\end{array}$ & $\begin{array}{l}-0.10 \\
{[-0.11]}\end{array}$ & $\begin{array}{c}-1.02 \\
{[0.1239]}\end{array}$ & $\begin{array}{c}0.69 \\
{[1.36]}\end{array}$ & $\begin{array}{c}0.47 \\
{[0.0240]}\end{array}$ & $\begin{array}{c}-0.07 \\
{[-0.21]}\end{array}$ & $\begin{array}{c}-0.05 \\
{[0.3322]}\end{array}$ \\
\hline
\end{tabular}




\begin{tabular}{|c|c|c|c|c|c|c|c|c|c|}
\hline \multirow{2}{*}{$\begin{array}{l}\text { Tax } \\
\text { overhang }\end{array}$} & \multirow{2}{*}{$\begin{array}{l}\text { Disposition } \\
\text { Effect }\end{array}$} & \multicolumn{2}{|c|}{$1980-2004$} & \multicolumn{2}{|c|}{$1980-86$} & \multicolumn{2}{|c|}{$1987-97$} & \multicolumn{2}{|c|}{$1998-2004$} \\
\hline & & Mean & Median & Mean & Median & Mean & Median & Mean & Median \\
\hline \multicolumn{10}{|c|}{ Panel B: Tax Overhang Deciles } \\
\hline \multirow[t]{3}{*}{1} & Nondisp & $\begin{array}{c}1.20 \\
{[1.71]}\end{array}$ & $\begin{array}{c}-1.77 \\
{[<.0001]}\end{array}$ & $\begin{array}{c}3.98 \\
{[1.81]}\end{array}$ & $\begin{array}{c}0.16 \\
{[1.0000]}\end{array}$ & $\begin{array}{c}7.07 \\
{[3.54]}\end{array}$ & $\begin{array}{c}1.07 \\
{[0.1421]}\end{array}$ & $\begin{array}{c}-1.66 \\
{[-3.29]}\end{array}$ & $\begin{array}{c}-3.01 \\
{[<.0001]}\end{array}$ \\
\hline & Disp & $\begin{array}{c}0.04 \\
{[0.11]}\end{array}$ & $\begin{array}{c}-2.58 \\
{[<.0001]}\end{array}$ & $\begin{array}{c}-0.88 \\
{[-1.24]}\end{array}$ & $\begin{array}{c}-2.33 \\
{[<.0001]}\end{array}$ & $\begin{array}{c}4.70 \\
{[6.17]}\end{array}$ & $\begin{array}{c}-0.68 \\
{[0.2718]}\end{array}$ & $\begin{array}{c}-3.67 \\
{[-9.22]}\end{array}$ & $\begin{array}{c}-4.50 \\
{[<.0001]}\end{array}$ \\
\hline & Difference & $\begin{array}{c}1.16 \\
{[1.49]}\end{array}$ & $\begin{array}{c}0.81 \\
{[0.0093]}\end{array}$ & $\begin{array}{c}4.87 \\
{[2.67]}\end{array}$ & $\begin{array}{c}2.17 \\
{[0.0135]}\end{array}$ & $\begin{array}{l}2.37 \\
1.30]\end{array}$ & $\begin{array}{c}1.75 \\
{[0.1072]}\end{array}$ & $\begin{array}{c}2.01 \\
{[2.97]}\end{array}$ & $\begin{array}{c}1.49 \\
{[<.0001]}\end{array}$ \\
\hline \multirow[t]{3}{*}{2} & Nondisp & $\begin{array}{c}3.85 \\
{[8.71]}\end{array}$ & $\begin{array}{c}-0.52 \\
{[0.0161]}\end{array}$ & $\begin{array}{c}2.67 \\
{[2.82]}\end{array}$ & $\begin{array}{c}-0.65 \\
{[0.2786]}\end{array}$ & $\begin{array}{c}8.63 \\
{[9.82]}\end{array}$ & $\begin{array}{c}2.65 \\
{[<.0001]}\end{array}$ & $\begin{array}{c}0.23 \\
{[0.51]}\end{array}$ & $\begin{array}{c}-2.20 \\
{[<.0001]}\end{array}$ \\
\hline & Disp & $\begin{array}{l}1.58 \\
{[4.62]}\end{array}$ & $\begin{array}{c}-1.08 \\
{[<.0001]}\end{array}$ & $\begin{array}{c}1.18 \\
{[1.40]}\end{array}$ & $\begin{array}{c}-1.49 \\
{[0.0111]}\end{array}$ & $\begin{array}{c}4.69 \\
{[8.13]}\end{array}$ & $\begin{array}{c}0.74 \\
{[0.0302]}\end{array}$ & $\begin{array}{c}-1.03 \\
{[-2.31]}\end{array}$ & $\begin{array}{c}-2.53 \\
{[<.0001]}\end{array}$ \\
\hline & Difference & $\begin{array}{c}2.27 \\
{[4.06]}\end{array}$ & $\begin{array}{c}0.56 \\
{[0.0088]}\end{array}$ & $\begin{array}{c}1.49 \\
{[1.15]}\end{array}$ & $\begin{array}{c}0.84 \\
{[0.1788]}\end{array}$ & $\begin{array}{c}3.95 \\
{[3.80]}\end{array}$ & $\begin{array}{c}1.91 \\
{[0.0056]}\end{array}$ & $\begin{array}{c}1.26 \\
{[1.98]}\end{array}$ & $\begin{array}{c}0.33 \\
{[0.0364]}\end{array}$ \\
\hline \multirow[t]{3}{*}{3} & Nondisp & $\begin{array}{c}4.06 \\
{[10.18]}\end{array}$ & $\begin{array}{c}0.46 \\
{[0.0506]}\end{array}$ & $\begin{array}{c}3.16 \\
{[3.67]}\end{array}$ & $\begin{array}{c}0.13 \\
{[0.9307]}\end{array}$ & $\begin{array}{c}7.04 \\
{[9.69]}\end{array}$ & $\begin{array}{c}2.14 \\
{[<.0001]}\end{array}$ & $\begin{array}{c}1.71 \\
{[3.45]}\end{array}$ & $\begin{array}{c}-0.80 \\
{[0.0229]}\end{array}$ \\
\hline & Disp & $\begin{array}{c}1.94 \\
{[5.67]}\end{array}$ & $\begin{array}{c}-0.68 \\
{[0.0002]}\end{array}$ & $\begin{array}{c}1.14 \\
{[1.52]}\end{array}$ & $\begin{array}{c}-1.29 \\
{[0.0338]}\end{array}$ & $\begin{array}{c}4.68 \\
{[7.63]}\end{array}$ & $\begin{array}{c}0.80 \\
{[0.0205]}\end{array}$ & $\begin{array}{c}-0.28 \\
{[-0.66]}\end{array}$ & $\begin{array}{c}-1.77 \\
{[<.0001]}\end{array}$ \\
\hline & Difference & $\begin{array}{c}2.12 \\
{[4.02]}\end{array}$ & $\begin{array}{c}1.14 \\
{[<.0001]}\end{array}$ & $\begin{array}{c}2.02 \\
{[1.75]}\end{array}$ & $\begin{array}{c}1.42 \\
{[0.0483]}\end{array}$ & $\begin{array}{c}2.36 \\
{[2.48]}\end{array}$ & $\begin{array}{c}1.34 \\
{[0.0053]}\end{array}$ & $\begin{array}{c}1.99 \\
{[3.05]}\end{array}$ & $\begin{array}{c}0.97 \\
{[0.0002]}\end{array}$ \\
\hline
\end{tabular}




\begin{tabular}{|c|c|c|c|c|c|c|c|c|c|}
\hline \multirow[t]{3}{*}{4} & Nondisp & $\begin{array}{c}4.64 \\
{[11.12]}\end{array}$ & $\begin{array}{c}0.35 \\
{[0.0523]}\end{array}$ & $\begin{array}{c}2.09 \\
{[2.23]}\end{array}$ & $\begin{array}{c}-0.85 \\
{[0.4437]}\end{array}$ & $\begin{array}{c}7.65 \\
{[10.01]}\end{array}$ & $\begin{array}{c}2.33 \\
{[<.0001]}\end{array}$ & $\begin{array}{c}2.52 \\
{[5.08]}\end{array}$ & $\begin{array}{c}-0.41 \\
{[0.0556]}\end{array}$ \\
\hline & Disp & $\begin{array}{c}1.99 \\
{[5.55]}\end{array}$ & $\begin{array}{c}-0.24 \\
{[0.2923]}\end{array}$ & $\begin{array}{c}2.16 \\
{[2.12]}\end{array}$ & $\begin{array}{c}-0.19 \\
{[0.8424]}\end{array}$ & $\begin{array}{c}3.60 \\
{[6.07]}\end{array}$ & $\begin{array}{c}0.87 \\
{[0.0344]}\end{array}$ & $\begin{array}{c}0.40 \\
{[0.84]}\end{array}$ & $\begin{array}{c}-1.25 \\
{[0.0004]}\end{array}$ \\
\hline & Difference & $\begin{array}{c}2.65 \\
{[4.72]}\end{array}$ & $\begin{array}{c}0.59 \\
{[<.0001]}\end{array}$ & $\begin{array}{c}-0.07 \\
{[-0.05]}\end{array}$ & $\begin{array}{c}-0.66 \\
{[0.3500]}\end{array}$ & $\begin{array}{c}4.05 \\
{[4.11]}\end{array}$ & $\begin{array}{c}1.46 \\
{[0.0001]}\end{array}$ & $\begin{array}{c}2.12 \\
{[3.05]}\end{array}$ & $\begin{array}{c}0.84 \\
{[0.0015]}\end{array}$ \\
\hline \multirow[t]{3}{*}{5} & Nondisp & $\begin{array}{c}3.72 \\
{[10.31]}\end{array}$ & $\begin{array}{c}0.48 \\
{[0.0402]}\end{array}$ & $\begin{array}{c}3.29 \\
{[3.22]}\end{array}$ & $\begin{array}{c}0.34 \\
{[0.6398]}\end{array}$ & $\begin{array}{c}5.68 \\
{[8.74]}\end{array}$ & $\begin{array}{c}1.94 \\
{[<.0001]}\end{array}$ & $\begin{array}{c}1.97 \\
{[4.77]}\end{array}$ & $\begin{array}{c}-0.34 \\
{[0.0831]}\end{array}$ \\
\hline & Disp & $\begin{array}{c}1.74 \\
{[5.11]}\end{array}$ & $\begin{array}{c}-0.34 \\
{[0.1685]}\end{array}$ & $\begin{array}{c}2.42 \\
{[2.28]}\end{array}$ & $\begin{array}{c}0.21 \\
{[0.3426]}\end{array}$ & $\begin{array}{c}3.39 \\
{[5.42]}\end{array}$ & $\begin{array}{c}0.14 \\
{[0.7751]}\end{array}$ & $\begin{array}{c}0.02 \\
{[0.06]}\end{array}$ & $\begin{array}{c}-0.98 \\
{[0.0041]}\end{array}$ \\
\hline & Difference & $\begin{array}{c}1.98 \\
{[3.96]}\end{array}$ & $\begin{array}{c}0.82 \\
{[<.0001]}\end{array}$ & $\begin{array}{c}0.87 \\
{[0.59]}\end{array}$ & $\begin{array}{c}0.13 \\
{[0.3302]}\end{array}$ & $\begin{array}{c}2.29 \\
{[2.52]}\end{array}$ & $\begin{array}{c}1.80 \\
{[0.0007]}\end{array}$ & $\begin{array}{c}1.94 \\
{[3.50]}\end{array}$ & $\begin{array}{c}0.64 \\
0.0015]\end{array}$ \\
\hline \multirow[t]{3}{*}{6} & Nondisp & $\begin{array}{c}2.74 \\
{[8.91]}\end{array}$ & $\begin{array}{c}0.25 \\
{[0.2276]}\end{array}$ & $\begin{array}{c}4.43 \\
{[4.18]}\end{array}$ & $\begin{array}{c}1.17 \\
{[0.0126]}\end{array}$ & $\begin{array}{c}3.74 \\
{[7.15]}\end{array}$ & $\begin{array}{c}1.42 \\
{[0.0002]}\end{array}$ & $\begin{array}{c}1.55 \\
{[4.01]}\end{array}$ & $\begin{array}{c}-0.64 \\
{[0.0055]}\end{array}$ \\
\hline & Disp & $\begin{array}{c}1.73 \\
{[4.76]}\end{array}$ & $\begin{array}{c}-0.54 \\
{[0.0022]}\end{array}$ & $\begin{array}{c}1.45 \\
{[2.24]}\end{array}$ & $\begin{array}{c}-0.29 \\
{[0.3821]}\end{array}$ & $\begin{array}{c}1.74 \\
{[2.98]}\end{array}$ & $\begin{array}{c}-0.64 \\
{[0.0159]}\end{array}$ & $\begin{array}{c}1.79 \\
{[3.25]}\end{array}$ & $\begin{array}{c}-0.52 \\
{[0.0981]}\end{array}$ \\
\hline & Difference & $\begin{array}{c}1.01 \\
{[2.12]}\end{array}$ & $\begin{array}{c}0.79 \\
{[0.0004]}\end{array}$ & $\begin{array}{c}2.98 \\
{[2.33]}\end{array}$ & $\begin{array}{c}1.46 \\
{[0.0370]}\end{array}$ & $\begin{array}{c}2.00 \\
{[2.55]}\end{array}$ & $\begin{array}{c}2.06 \\
{[<.0001]}\end{array}$ & $\begin{array}{c}-0.24 \\
{[-0.37]}\end{array}$ & $\begin{array}{c}-0.12 \\
{[0.2796]}\end{array}$ \\
\hline \multirow[t]{3}{*}{7} & Nondisp & $\begin{array}{c}3.18 \\
{[10.10]}\end{array}$ & $\begin{array}{c}0.51 \\
{[0.0047]}\end{array}$ & $\begin{array}{c}3.62 \\
{[3.06]}\end{array}$ & $\begin{array}{c}0.49 \\
{[0.2869]}\end{array}$ & $\begin{array}{c}4.10 \\
{[8.09]}\end{array}$ & $\begin{array}{c}0.93 \\
{[0.0028]}\end{array}$ & $\begin{array}{c}2.17 \\
{[5.37]}\end{array}$ & $\begin{array}{c}0.14 \\
{[0.5147]}\end{array}$ \\
\hline & Disp & $\begin{array}{c}0.68 \\
{[2.66]}\end{array}$ & $\begin{array}{c}-0.61 \\
{[0.0003]}\end{array}$ & $\begin{array}{c}0.28 \\
{[0.41]}\end{array}$ & $\begin{array}{c}-1.39 \\
{[0.0046]}\end{array}$ & $\begin{array}{c}0.54 \\
{[1.43]}\end{array}$ & $\begin{array}{c}-0.47 \\
{[0.0838]}\end{array}$ & $\begin{array}{c}0.88 \\
{[2.28]}\end{array}$ & $\begin{array}{c}-0.50 \\
{[0.0249]}\end{array}$ \\
\hline & Difference & $\begin{array}{c}2.50 \\
{[5.81]}\end{array}$ & $\begin{array}{c}1.12 \\
{[<.0001]}\end{array}$ & $\begin{array}{c}3.34 \\
{[2.21]}\end{array}$ & $\begin{array}{c}1.88 \\
{[0.0038]}\end{array}$ & $\begin{array}{c}3.56 \\
{[5.16]}\end{array}$ & $\begin{array}{c}1.40 \\
{[<.0001]}\end{array}$ & $\begin{array}{c}1.29 \\
{[2.23]}\end{array}$ & $\begin{array}{c}0.64 \\
{[0.0240]}\end{array}$ \\
\hline
\end{tabular}




\begin{tabular}{|c|c|c|c|c|c|c|c|c|c|}
\hline \multirow[t]{3}{*}{8} & Nondisp & $\begin{array}{c}1.39 \\
{[5.73]}\end{array}$ & $\begin{array}{c}-0.43 \\
{[0.0112]}\end{array}$ & $\begin{array}{c}0.29 \\
{[0.59]}\end{array}$ & $\begin{array}{c}-0.60 \\
{[0.1417]}\end{array}$ & $\begin{array}{c}1.80 \\
{[4.88]}\end{array}$ & $\begin{array}{c}-0.02 \\
{[0.8406]}\end{array}$ & $\begin{array}{c}1.22 \\
{[3.24]}\end{array}$ & $\begin{array}{c}-0.56 \\
{[0.0050]}\end{array}$ \\
\hline & Disp & $\begin{array}{c}0.67 \\
{[2.40]}\end{array}$ & $\begin{array}{c}-0.53 \\
{[0.0000]}\end{array}$ & $\begin{array}{c}0.32 \\
{[0.71]}\end{array}$ & $\begin{array}{c}-0.64 \\
{[0.3742]}\end{array}$ & $\begin{array}{c}0.35 \\
{[0.80]}\end{array}$ & $\begin{array}{c}-0.98 \\
{[<.0001]}\end{array}$ & $\begin{array}{c}1.00 \\
{[2.46]}\end{array}$ & $\begin{array}{c}-0.13 \\
{[0.3715]}\end{array}$ \\
\hline & Difference & $\begin{array}{c}0.72 \\
{[1.94]}\end{array}$ & $\begin{array}{c}0.10 \\
{[0.0694]}\end{array}$ & $\begin{array}{c}-0.03 \\
{[-0.05]}\end{array}$ & $\begin{array}{c}0.04 \\
{[0.3332]}\end{array}$ & $\begin{array}{c}1.44 \\
{[2.48]}\end{array}$ & $\begin{array}{c}0.96 \\
{[0.0009]}\end{array}$ & $\begin{array}{c}0.22 \\
{[0.38]}\end{array}$ & $\begin{array}{c}-0.43 \\
{[0.2145]}\end{array}$ \\
\hline \multirow[t]{3}{*}{9} & Nondisp & $\begin{array}{c}0.75 \\
{[3.43]}\end{array}$ & $\begin{array}{c}-0.73 \\
{[<.0001]}\end{array}$ & $\begin{array}{c}0.76 \\
{[0.96]}\end{array}$ & $\begin{array}{c}-1.61 \\
{[0.0004]}\end{array}$ & $\begin{array}{c}1.25 \\
{[3.21]}\end{array}$ & $\begin{array}{c}-0.55 \\
{[0.0022]}\end{array}$ & $\begin{array}{c}0.31 \\
{[1.23]}\end{array}$ & $\begin{array}{c}-0.74 \\
{[0.0000]}\end{array}$ \\
\hline & Disp & $\begin{array}{c}0.24 \\
{[0.97]}\end{array}$ & $\begin{array}{c}-0.87 \\
{[<.0001]}\end{array}$ & $\begin{array}{c}0.69 \\
{[1.18]}\end{array}$ & $\begin{array}{c}0.05 \\
{[1.0000]}\end{array}$ & $\begin{array}{c}0.27 \\
{[0.70]}\end{array}$ & $\begin{array}{c}-0.94 \\
{[0.0000]}\end{array}$ & $\begin{array}{c}0.11 \\
{[0.32]}\end{array}$ & $\begin{array}{c}-1.13 \\
{[<.0001]}\end{array}$ \\
\hline & Difference & $\begin{array}{c}0.51 \\
{[1.52]}\end{array}$ & $\begin{array}{c}0.14 \\
{[0.1293]}\end{array}$ & $\begin{array}{c}0.07 \\
{[0.06]}\end{array}$ & $\begin{array}{c}-1.66 \\
{[0.0126]}\end{array}$ & $\begin{array}{c}0.98 \\
{[1.74]}\end{array}$ & $\begin{array}{c}0.49 \\
{[0.0736]}\end{array}$ & $\begin{array}{c}0.20 \\
{[0.46]}\end{array}$ & $\begin{array}{c}0.39 \\
{[00961]}\end{array}$ \\
\hline \multirow[t]{3}{*}{10} & Nondisp & $\begin{array}{c}1.43 \\
{[4.14]}\end{array}$ & $\begin{array}{c}-0.91 \\
{[<.0001]}\end{array}$ & $\begin{array}{c}0.11 \\
{[0.15]}\end{array}$ & $\begin{array}{c}-1.44 \\
{[0.0066]}\end{array}$ & $\begin{array}{c}2.89 \\
{[4.53]}\end{array}$ & $\begin{array}{c}-0.54 \\
{[0.0071]}\end{array}$ & $\begin{array}{c}0.37 \\
{[0.93]}\end{array}$ & $\begin{array}{c}-1.13 \\
{[<.0001]}\end{array}$ \\
\hline & Disp & $\begin{array}{c}1.23 \\
{[3.94]}\end{array}$ & $\begin{array}{c}-0.95 \\
{[<.0001]}\end{array}$ & $\begin{array}{c}-0.15 \\
{[-0.21]}\end{array}$ & $\begin{array}{c}-1.73 \\
{[0.0010]}\end{array}$ & $\begin{array}{c}1.96 \\
{[3.68]}\end{array}$ & $\begin{array}{c}-0.97 \\
{[<.0001]}\end{array}$ & $\begin{array}{c}0.80 \\
{[1.94]}\end{array}$ & $\begin{array}{c}-0.67 \\
{[0.0014]}\end{array}$ \\
\hline & Difference & $\begin{array}{c}0.20 \\
{[0.41]}\end{array}$ & $\begin{array}{c}0.04 \\
{[0.3551]}\end{array}$ & $\begin{array}{c}0.26 \\
{[0.26]}\end{array}$ & $\begin{array}{c}0.27 \\
{[0.3465]}\end{array}$ & $\begin{array}{c}0.93 \\
{[1.09]}\end{array}$ & $\begin{array}{c}0.43 \\
{[0.0621]}\end{array}$ & $\begin{array}{c}-0.43 \\
{[-0.72]}\end{array}$ & $\begin{array}{c}-0.36 \\
{[0.0373]}\end{array}$ \\
\hline
\end{tabular}




\section{Table 11: Disposition Effect and Fund Flows Controlling for Performance and Tax Overhang}

This table compares the level of fund flows between funds exhibiting strong disposition effects and funds without such behavior controlling for performance and tax overhang. Every quarter and within each investment category, funds are first sorted into deciles based on their returns in the previous quarter. Funds in the same performance decile are further sorted into quintiles based on their tax overhangs over the performance measurement period. Funds in the top 2 quintiles have the highest tax overhang (High), and funds in the bottom 2 quintiles have the lowest tax overhang (Low). Finally, funds in the same performance decile and overhang group are sorted into quintiles based on their disposition spreads over the performance measurement period. Funds in the top quintiles have the highest disposition spread (Disp), and funds in the bottom quintile have the lowest disposition spread (Nondisp). In the quarter immediately after the portfolio formation period, portfolio flows are calculated by equally weighting flows to the funds included in the ortfolio. Fund flow is calculated as $F L_{i, t}=\frac{T N A_{i, t}-T N A_{i, t-1}\left(1+r_{i, t}\right)}{T N A_{i, t-1}}$, where $T N A_{i, t}$ is the total net assets of fund $i$ at the end of quarter $t$, and $r_{i, t}$ is the total return of fund $i$ in quarter $t$. The time-series means and medians of the portfolio flows are reported in Panel B. We also compare fund flows on an aggregate level. Funds in the bottom 2 return deciles are grouped into Low performance group (Low), funds in the middle 6 deciles are grouped into Medium performance group (Med), and funds in the top 2 deciles are grouped into High performance group (High). Within each return group, funds in the top 2 overhang quintiles are grouped into high tax overhang portfolio, and bottom 2 overhang quintiles into low tax overhang portfolios. Finally, funds with the highest disposition spread (Disp) and lowest disposition spread (Nondisp) are further grouped into portfolios. Portfolio flows are calculated by equally weighting fund flows. The time-series means and medians of portfolio flows by return groups are reported in Panel A. The portfolio analysis is performed over the whole sample period of 19802004, and also for three sub-sample periods divided based on the capital gains tax rate changes. T-statistics for means and p-values for medians are reported in brackets. 


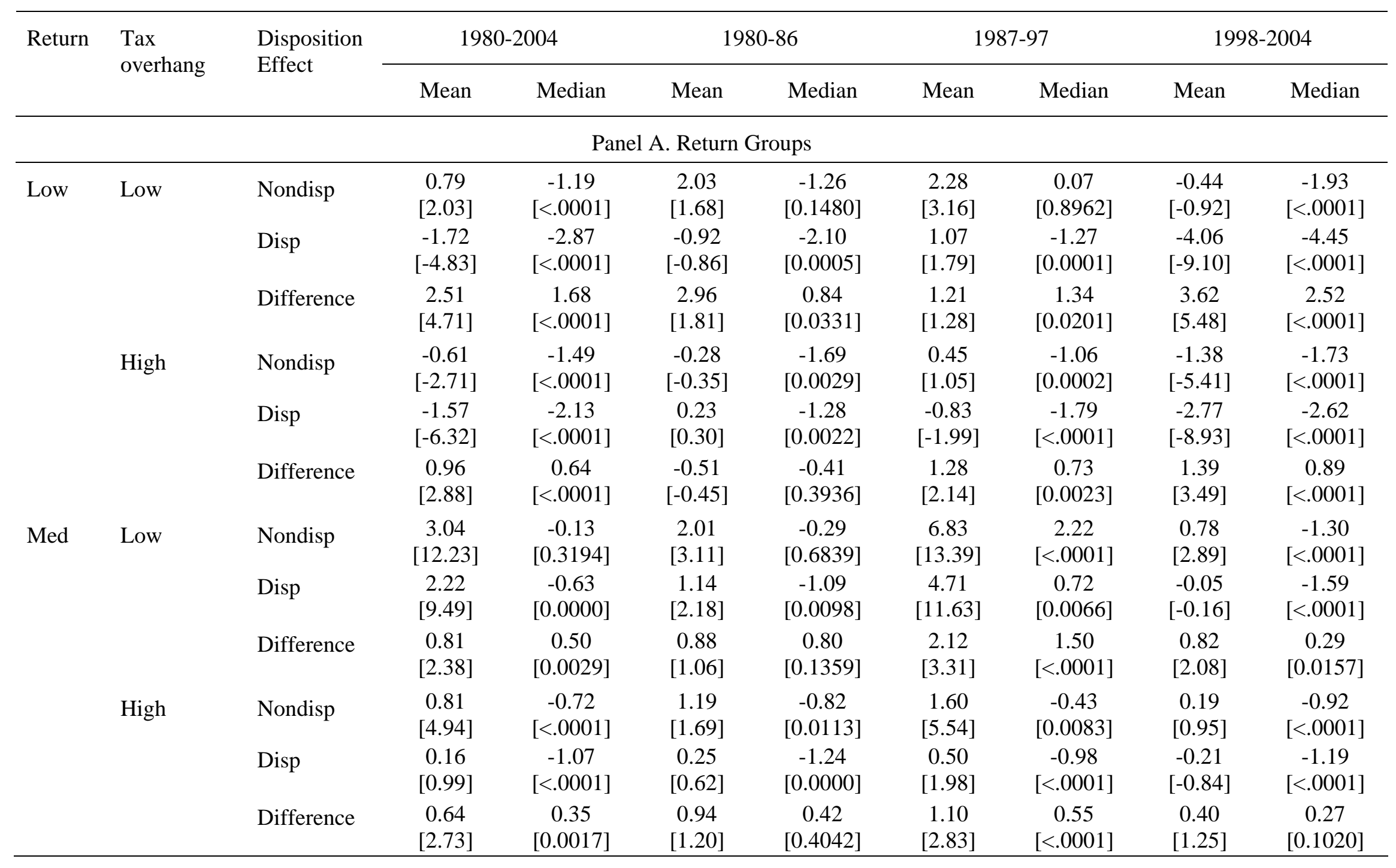




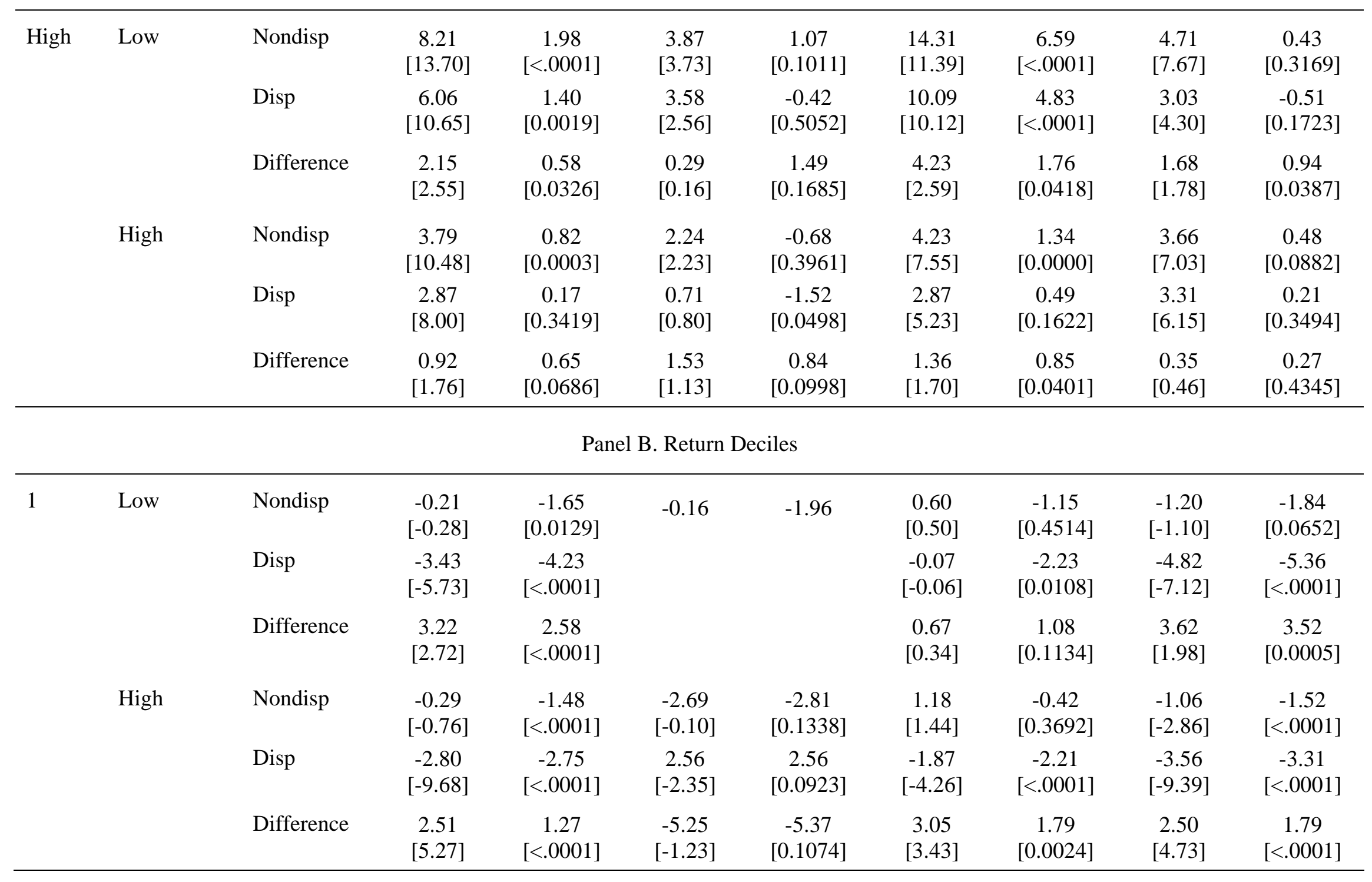




\begin{tabular}{|c|c|c|c|c|c|c|c|c|c|c|}
\hline \multirow[t]{6}{*}{2} & Low & Nondisp & $\begin{array}{c}0.82 \\
{[1.55]}\end{array}$ & $\begin{array}{c}-1.07 \\
{[0.0004]}\end{array}$ & $\begin{array}{c}-0.99 \\
{[-0.37]}\end{array}$ & $\begin{array}{c}-2.92 \\
{[0.3750]}\end{array}$ & $\begin{array}{c}2.75 \\
{[2.80]}\end{array}$ & $\begin{array}{c}0.54 \\
{[0.4880]}\end{array}$ & $\begin{array}{c}-0.19 \\
{[-0.30]}\end{array}$ & $\begin{array}{c}-1.82 \\
{[<.0001]}\end{array}$ \\
\hline & & Disp & $\begin{array}{c}-0.35 \\
{[-0.70]}\end{array}$ & $\begin{array}{c}-2.13 \\
{[<.0001]}\end{array}$ & $\begin{array}{c}-3.00 \\
{[-1.08]}\end{array}$ & $\begin{array}{c}-6.28 \\
{[0.3438]}\end{array}$ & $\begin{array}{c}2.47 \\
{[2.98]}\end{array}$ & $\begin{array}{c}-0.40 \\
{[0.1854]}\end{array}$ & $\begin{array}{c}-3.10 \\
{[-5.74]}\end{array}$ & $\begin{array}{c}-3.41 \\
{[<.0001]}\end{array}$ \\
\hline & & Difference & $\begin{array}{c}1.17 \\
{[1.60]}\end{array}$ & $\begin{array}{c}1.06 \\
{[0.0147]}\end{array}$ & $\begin{array}{c}2.01 \\
{[0.46]}\end{array}$ & $\begin{array}{c}3.36 \\
{[0.2130]}\end{array}$ & $\begin{array}{c}0.28 \\
{[0.22]}\end{array}$ & $\begin{array}{c}0.94 \\
{[0.2485]}\end{array}$ & $\begin{array}{c}2.91 \\
{[3.46]}\end{array}$ & $\begin{array}{c}1.59 \\
{[0.0002]}\end{array}$ \\
\hline & High & Nondisp & $\begin{array}{c}-0.75 \\
{[-2.43]}\end{array}$ & $\begin{array}{c}-1.49 \\
{[<.0001]}\end{array}$ & $\begin{array}{c}1.57 \\
{[0.76]}\end{array}$ & $\begin{array}{c}-1.53 \\
{[0.4545]}\end{array}$ & $\begin{array}{c}0.30 \\
{[0.58]}\end{array}$ & $\begin{array}{c}-1.24 \\
{[0.0017]}\end{array}$ & $\begin{array}{c}-1.71 \\
{[-4.65]}\end{array}$ & $\begin{array}{c}-1.94 \\
{[<.0001]}\end{array}$ \\
\hline & & Disp & $\begin{array}{c}-0.81 \\
{[-1.94]}\end{array}$ & $\begin{array}{c}-1.66 \\
{[<.0001]}\end{array}$ & $\begin{array}{c}1.09 \\
{[0.61]}\end{array}$ & $\begin{array}{c}-2.24 \\
{[0.1878]}\end{array}$ & $\begin{array}{c}-0.13 \\
{[-0.19]}\end{array}$ & $\begin{array}{c}-1.34 \\
{[<.0001]}\end{array}$ & $\begin{array}{c}-1.77 \\
{[-3.64]}\end{array}$ & $\begin{array}{c}-2.18 \\
{[<.0001]}\end{array}$ \\
\hline & & Difference & $\begin{array}{c}0.06 \\
{[0.11]}\end{array}$ & $\begin{array}{c}0.17 \\
{[0.2051]}\end{array}$ & $\begin{array}{c}0.47 \\
{[0.16]}\end{array}$ & $\begin{array}{c}0.71 \\
{[0.3038]}\end{array}$ & $\begin{array}{c}0.43 \\
{[0.51]}\end{array}$ & $\begin{array}{c}0.10 \\
{[0.1451]}\end{array}$ & $\begin{array}{c}0.06 \\
{[0.10]}\end{array}$ & $\begin{array}{c}0.24 \\
{[0.3401]}\end{array}$ \\
\hline \multirow[t]{6}{*}{3} & Low & Nondisp & $\begin{array}{c}1.16 \\
{[2.32]}\end{array}$ & $\begin{array}{c}-1.38 \\
{[0.0004]}\end{array}$ & $\begin{array}{c}1.13 \\
{[0.90]}\end{array}$ & $\begin{array}{c}-0.97 \\
{[0.5424]}\end{array}$ & $\begin{array}{c}4.08 \\
{[4.04]}\end{array}$ & $\begin{array}{c}0.26 \\
{[0.2757]}\end{array}$ & $\begin{array}{c}-0.83 \\
{[-1.50]}\end{array}$ & $\begin{array}{c}-2.48 \\
{[<.0001]}\end{array}$ \\
\hline & & Disp & $\begin{array}{c}0.66 \\
{[1.37]}\end{array}$ & $\begin{array}{c}-1.13 \\
{[0.0001]}\end{array}$ & $\begin{array}{c}-0.94 \\
{[-1.24]}\end{array}$ & $\begin{array}{c}-1.56 \\
{[0.0062]}\end{array}$ & $\begin{array}{c}4.07 \\
{[4.37]}\end{array}$ & $\begin{array}{c}0.69 \\
{[0.1903]}\end{array}$ & $\begin{array}{c}-1.87 \\
{[-3.46]}\end{array}$ & $\begin{array}{c}-2.44 \\
{[<.0001]}\end{array}$ \\
\hline & & Difference & $\begin{array}{c}0.50 \\
{[0.72]}\end{array}$ & $\begin{array}{c}-0.25 \\
{[0.3823]}\end{array}$ & $\begin{array}{c}2.07 \\
{[1.48]}\end{array}$ & $\begin{array}{c}0.59 \\
{[0.2444]}\end{array}$ & $\begin{array}{c}0.01 \\
{[0.01]}\end{array}$ & $\begin{array}{c}-0.43 \\
{[0.4532]}\end{array}$ & $\begin{array}{c}1.04 \\
{[1.35]}\end{array}$ & $\begin{array}{c}-0.04 \\
{[0.1989]}\end{array}$ \\
\hline & High & Nondisp & $\begin{array}{c}0.59 \\
{[1.21]}\end{array}$ & $\begin{array}{c}-1.15 \\
{[<.0001]}\end{array}$ & $\begin{array}{c}1.24 \\
{[0.69]}\end{array}$ & $\begin{array}{c}-2.06 \\
{[0.0019]}\end{array}$ & $\begin{array}{c}2.48 \\
{[2.33]}\end{array}$ & $\begin{array}{c}-0.77 \\
{[0.1036]}\end{array}$ & $\begin{array}{c}-0.87 \\
{[-2.16]}\end{array}$ & $\begin{array}{c}-1.17 \\
{[<.0001]}\end{array}$ \\
\hline & & Disp & $\begin{array}{c}-1.06 \\
{[-3.23]}\end{array}$ & $\begin{array}{c}-1.69 \\
{[<.0001]}\end{array}$ & $\begin{array}{c}-0.30 \\
{[-0.44]}\end{array}$ & $\begin{array}{c}-1.41 \\
{[0.0027]}\end{array}$ & $\begin{array}{c}-0.63 \\
{[-1.34]}\end{array}$ & $\begin{array}{c}-1.27 \\
{[0.0002]}\end{array}$ & $\begin{array}{c}-1.74 \\
{[-3.14]}\end{array}$ & $\begin{array}{c}-2.13 \\
{[<.0001]}\end{array}$ \\
\hline & & Difference & $\begin{array}{c}1.65 \\
{[2.70]}\end{array}$ & $\begin{array}{c}0.54 \\
{[0.0153]}\end{array}$ & $\begin{array}{c}1.54 \\
{[0.94]}\end{array}$ & $\begin{array}{c}-0.55 \\
{[0.3541]}\end{array}$ & $\begin{array}{c}3.11 \\
{[2.60]}\end{array}$ & $\begin{array}{c}0.50 \\
{[0.0422]}\end{array}$ & $\begin{array}{c}0.87 \\
{[1.29]}\end{array}$ & $\begin{array}{c}0.96 \\
{[0.0251]}\end{array}$ \\
\hline \multirow[t]{3}{*}{4} & Low & Nondisp & $\begin{array}{c}2.04 \\
{[3.82]}\end{array}$ & $\begin{array}{c}-0.79 \\
{[0.0198]}\end{array}$ & $\begin{array}{c}0.75 \\
{[0.68]}\end{array}$ & $\begin{array}{c}-0.78 \\
{[0.4408]}\end{array}$ & $\begin{array}{c}6.64 \\
{[6.33]}\end{array}$ & $\begin{array}{c}3.39 \\
{[0.0000]}\end{array}$ & $\begin{array}{c}-0.65 \\
{[-1.06]}\end{array}$ & $\begin{array}{c}-2.06 \\
{[<.0001]}\end{array}$ \\
\hline & & Disp & $\begin{array}{c}1.22 \\
{[2.39]}\end{array}$ & $\begin{array}{c}-1.29 \\
{[0.0000]}\end{array}$ & $\begin{array}{c}-0.18 \\
{[-0.21]}\end{array}$ & $\begin{array}{c}-1.53 \\
{[0.0078]}\end{array}$ & $\begin{array}{c}3.54 \\
{[3.95]}\end{array}$ & $\begin{array}{c}-0.19 \\
{[0.8844]}\end{array}$ & $\begin{array}{c}-0.78 \\
{[-1.20]}\end{array}$ & $\begin{array}{c}-2.70 \\
{[<.0001]}\end{array}$ \\
\hline & & Difference & $\begin{array}{c}0.82 \\
{[1.11]}\end{array}$ & $\begin{array}{c}0.50 \\
{[0.0771]}\end{array}$ & $\begin{array}{c}0.93 \\
{[0.67]}\end{array}$ & $\begin{array}{c}0.75 \\
{[0.1642]}\end{array}$ & $\begin{array}{c}3.10 \\
{[2.26]}\end{array}$ & $\begin{array}{c}3.58 \\
{[0.0006]}\end{array}$ & $\begin{array}{c}0.14 \\
{[0.15]}\end{array}$ & $\begin{array}{c}0.64 \\
{[0.4104]}\end{array}$ \\
\hline
\end{tabular}




\begin{tabular}{|c|c|c|c|c|c|c|c|c|c|c|}
\hline & High & Nondisp & $\begin{array}{c}-0.15 \\
{[-0.46]}\end{array}$ & $\begin{array}{c}-1.08 \\
{[<.0001]}\end{array}$ & $\begin{array}{c}-0.22 \\
{[-0.41]}\end{array}$ & $\begin{array}{c}-0.32 \\
{[0.1352]}\end{array}$ & $\begin{array}{c}0.75 \\
{[1.05]}\end{array}$ & $\begin{array}{c}-0.51 \\
{[0.0336]}\end{array}$ & $\begin{array}{c}-0.71 \\
{[-1.86]}\end{array}$ & $\begin{array}{c}-1.55 \\
{[<.0001]}\end{array}$ \\
\hline & & Disp & $\begin{array}{c}-0.14 \\
{[-0.36]}\end{array}$ & $\begin{array}{c}-1.38 \\
{[<.0001]}\end{array}$ & $\begin{array}{c}1.30 \\
{[0.92]}\end{array}$ & $\begin{array}{c}-0.93 \\
{[0.3240]}\end{array}$ & $\begin{array}{c}0.89 \\
{[1.32]}\end{array}$ & $\begin{array}{c}-0.90 \\
{[0.0101]}\end{array}$ & $\begin{array}{c}-1.64 \\
{[-3.64]}\end{array}$ & $\begin{array}{c}-2.32 \\
{[<.0001]}\end{array}$ \\
\hline \multirow[t]{4}{*}{5} & Low & Nondisp & $\begin{array}{c}2.22 \\
{[4.07]}\end{array}$ & $\begin{array}{c}-0.18 \\
{[0.4300]}\end{array}$ & $\begin{array}{c}1.98 \\
{[1.77]}\end{array}$ & $\begin{array}{c}1.10 \\
{[0.1539]}\end{array}$ & $\begin{array}{c}5.67 \\
{[4.90]}\end{array}$ & $\begin{array}{c}1.53 \\
{[0.0052]}\end{array}$ & $\begin{array}{c}-0.05 \\
{[-0.08]}\end{array}$ & $\begin{array}{c}-1.86 \\
{[0.0000]}\end{array}$ \\
\hline & & Difference & $\begin{array}{c}0.01 \\
{[0.02]}\end{array}$ & $\begin{array}{c}0.03 \\
{[0.3445]}\end{array}$ & $\begin{array}{c}0.21 \\
{[0.12]}\end{array}$ & $\begin{array}{c}1.75 \\
{[0.1464]}\end{array}$ & $\begin{array}{c}1.03 \\
{[0.71]}\end{array}$ & $\begin{array}{c}0.16 \\
{[0.2581]}\end{array}$ & $\begin{array}{c}0.44 \\
{[0.50]}\end{array}$ & $\begin{array}{c}0.11 \\
{[0.0880]}\end{array}$ \\
\hline & High & Nondisp & $\begin{array}{c}0.71 \\
{[1.65]}\end{array}$ & $\begin{array}{c}-0.66 \\
{[0.0005]}\end{array}$ & $\begin{array}{c}-1.22 \\
{[-1.85]}\end{array}$ & $\begin{array}{c}-1.52 \\
{[0.0115]}\end{array}$ & $\begin{array}{c}1.31 \\
{[1.84]}\end{array}$ & $\begin{array}{c}-0.30 \\
{[0.2839]}\end{array}$ & $\begin{array}{c}0.55 \\
{[0.91]}\end{array}$ & $\begin{array}{c}-0.74 \\
{[0.0056]}\end{array}$ \\
\hline & & Disp & $\begin{array}{c}-0.44 \\
{[-1.19]}\end{array}$ & $\begin{array}{c}-1.09 \\
{[<.0001]}\end{array}$ & $\begin{array}{c}-0.27 \\
{[-0.41]}\end{array}$ & $\begin{array}{c}-1.17 \\
{[0.1934]}\end{array}$ & $\begin{array}{c}-0.49 \\
{[-1.02]}\end{array}$ & $\begin{array}{c}-1.24 \\
{[<.0001]}\end{array}$ & $\begin{array}{c}-0.44 \\
{[-0.63]}\end{array}$ & $\begin{array}{c}-0.53 \\
{[0.0882]}\end{array}$ \\
\hline \multirow{5}{*}{6} & & Disp & $\begin{array}{c}2.42 \\
{[4.38]}\end{array}$ & $\begin{array}{c}-0.40 \\
{[0.1367]}\end{array}$ & $\begin{array}{c}0.12 \\
{[0.17]}\end{array}$ & $\begin{array}{c}-0.52 \\
{[0.4296]}\end{array}$ & $\begin{array}{c}3.79 \\
{[4.27]}\end{array}$ & $\begin{array}{c}0.10 \\
{[1.0000]}\end{array}$ & $\begin{array}{c}1.42 \\
{[1.74]}\end{array}$ & $\begin{array}{c}-1.04 \\
{[0.0669]}\end{array}$ \\
\hline & & Difference & $\begin{array}{c}1.47 \\
{[1.78]}\end{array}$ & $\begin{array}{c}0.65 \\
{[0.0760]}\end{array}$ & $\begin{array}{c}4.58 \\
{[2.05]}\end{array}$ & $\begin{array}{c}1.14 \\
{[0.1954]}\end{array}$ & $\begin{array}{c}2.84 \\
{[2.00]}\end{array}$ & $\begin{array}{c}2.90 \\
{[0.0057]}\end{array}$ & $\begin{array}{c}0.67 \\
{[0.60]}\end{array}$ & $\begin{array}{c}0.01 \\
{[0.3887]}\end{array}$ \\
\hline & High & Nondisp & $\begin{array}{c}0.26 \\
{[0.89]}\end{array}$ & $\begin{array}{c}-0.85 \\
{[<.0001]}\end{array}$ & $\begin{array}{c}0.51 \\
{[0.48]}\end{array}$ & $\begin{array}{c}-0.74 \\
{[0.6440]}\end{array}$ & $\begin{array}{c}1.08 \\
{[2.33]}\end{array}$ & $\begin{array}{c}-0.52 \\
{[0.1393]}\end{array}$ & $\begin{array}{c}-0.35 \\
{[-0.87]}\end{array}$ & $\begin{array}{c}-1.12 \\
{[<.0001]}\end{array}$ \\
\hline & & Disp & $\begin{array}{c}0.61 \\
{[1.47]}\end{array}$ & $\begin{array}{c}-0.70 \\
{[0.0002]}\end{array}$ & $\begin{array}{c}0.96 \\
{[1.10]}\end{array}$ & $\begin{array}{c}-0.68 \\
{[0.5682]}\end{array}$ & $\begin{array}{c}0.54 \\
{[0.76]}\end{array}$ & $\begin{array}{c}-1.08 \\
{[<.0001]}\end{array}$ & $\begin{array}{c}0.57 \\
{[1.00]}\end{array}$ & $\begin{array}{c}-0.16 \\
{[0.4684]}\end{array}$ \\
\hline & & Difference & $\begin{array}{c}-0.35 \\
{[-0.70]}\end{array}$ & $\begin{array}{c}-0.15 \\
{[0.3259]}\end{array}$ & $\begin{array}{c}-0.45 \\
{[-0.33]}\end{array}$ & $\begin{array}{c}-0.06 \\
{[0.3236]}\end{array}$ & $\begin{array}{c}0.54 \\
{[0.66]}\end{array}$ & $\begin{array}{c}0.56 \\
{[0.0191]}\end{array}$ & $\begin{array}{c}-0.92 \\
{[-1.33]}\end{array}$ & $\begin{array}{c}-0.96 \\
{[0.0235]}\end{array}$ \\
\hline
\end{tabular}




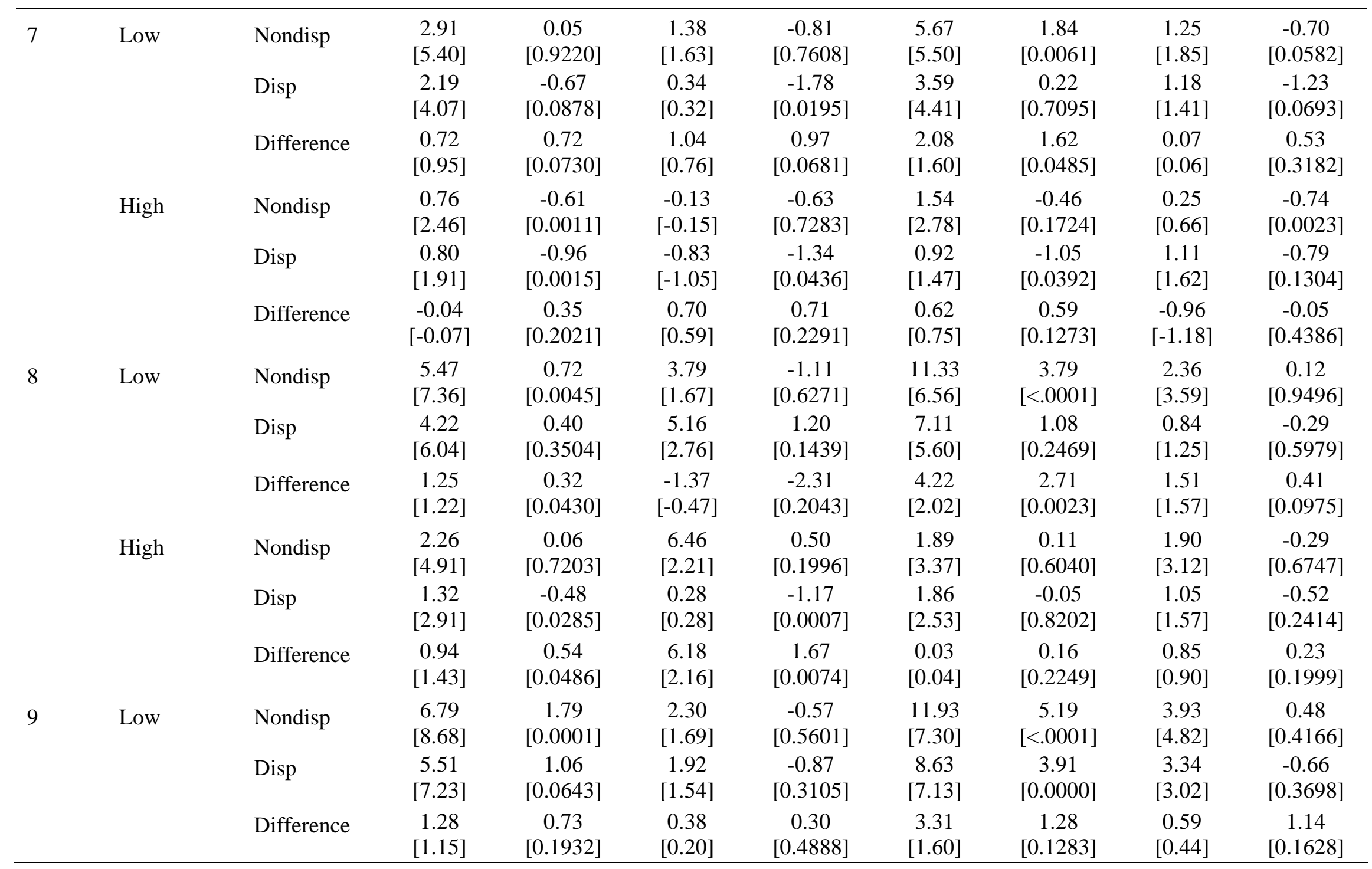




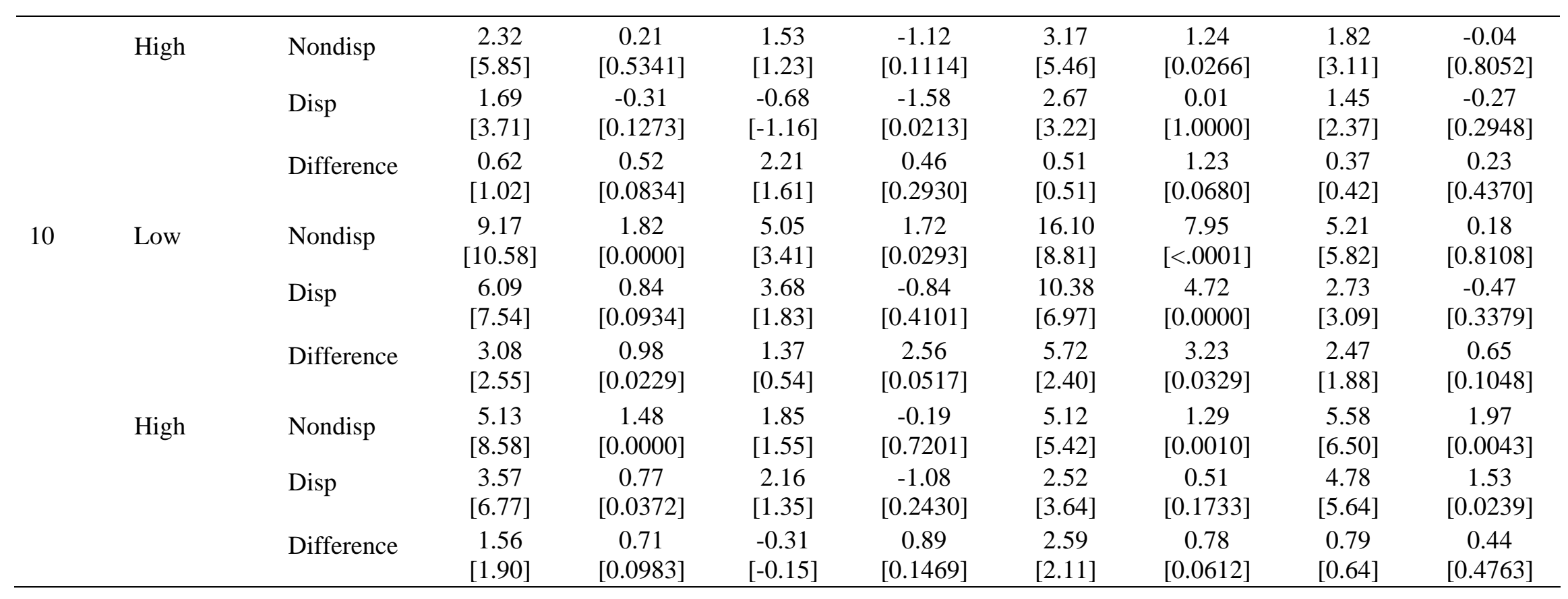




\section{Table 12: Tax Overhang, Disposition Effect and Fund Flows}

This table examines the influence of the disposition effect and tax overhang on fund flows. Each quarter and within each investment objective categories, all funds are ranked based on their previous quarter returns, and assigned a continuous rank ranging from zero (worst) to one (best), with the rankings corresponding to their performance percentiles. Funds in the bottom return deciles are aggregated into Low group (Low), the middle 6 deciles into Medium performance group (Med) and the top 2 deciles into High performance group (High). The factional rank for funds in Low group is defined as Min (Rank, 0.2). Funds in Med group receive ranks defined as Min (0.6, Rank - Low). Funds in High group are defined as Rank -Mid - Low. Each quarter a piecewise linear regression is performed by regressing quarterly flows on funds' fractional performance ranks over the low, medium and high performance ranges, the interaction terms of performance rank with funds' average disposition spread over the measurement period, and tax overhang as in equation

Flow $_{i, t}=\alpha_{i, t}+b_{1} \times$ Low $_{i, t-1}+b_{2} \times$ Med $_{i, t-1}+b_{3} \times$ High $_{i, t-1}+b_{4} \times$ Disposition $_{i, t-1}$

$+b_{5} \times$ Overhang $_{i, t-1}+$ Controls $+\varepsilon_{i, t}$

The control variables include volatility of monthly returns during the disposition effect measurement period, fund age, natural log of fund size measured by the previous year-end total net asset value, aggregate flow into the fund objective category, expense ratio, and total fee ratio. Regressions are conducted over the whole sample period and also over three sub-sample periods. Time-series average coefficients from Fama-MacBeth regressions and t-statistics (in parentheses) are reported. *, **, and $* * *$ denote significance at $10 \%, 5 \%$ and $1 \%$ level, respectively. 


\begin{tabular}{|c|c|c|c|c|}
\hline & $1980-2004$ & $1980-86$ & 1987-97 & 1998-2004 \\
\hline Intercept & $\begin{array}{l}-0.0145^{* * *} \\
{[-2.57]}\end{array}$ & $\begin{array}{l}-0.0360 * * * \\
{[-3.03]}\end{array}$ & $\begin{array}{l}0.0026 \\
{[0.33]}\end{array}$ & $\begin{array}{l}-0.0265^{* * *} \\
{[-2.58]}\end{array}$ \\
\hline Low & $\begin{array}{l}0.0942 * * * \\
{[7.34]}\end{array}$ & $\begin{array}{l}0.0744 * * * \\
{[2.32]}\end{array}$ & $\begin{array}{l}0.1185^{* * *} \\
{[6.35]}\end{array}$ & $\begin{array}{l}0.0850 * * * \\
{[5.00]}\end{array}$ \\
\hline Mid & $\begin{array}{l}0.0343^{* * *} \\
{[8.56]}\end{array}$ & $\begin{array}{l}0.0149 * * * \\
{[2.05]}\end{array}$ & $\begin{array}{l}0.0362 * * * \\
{[7.26]}\end{array}$ & $\begin{array}{l}0.0511^{* * *} \\
{[5.91]}\end{array}$ \\
\hline High & $\begin{array}{l}0.1805^{* * *} \\
{[9.76]}\end{array}$ & $\begin{array}{l}0.1163^{* * *} \\
{[3.39]}\end{array}$ & $\begin{array}{l}0.2138^{* * *} \\
{[6.62]}\end{array}$ & $\begin{array}{l}0.1831^{* * *} \\
{[7.25]}\end{array}$ \\
\hline Disposition & $\begin{array}{l}-0.0102^{* * *} \\
{[-3.85]}\end{array}$ & $\begin{array}{l}-0.0198 * * * \\
{[-5.81]}\end{array}$ & $\begin{array}{l}-0.0133 * * * \\
{[-2.73]}\end{array}$ & $\begin{array}{l}-0.0007 * * * \\
{[-0.21]}\end{array}$ \\
\hline Overhang & $\begin{array}{l}-0.0017 \\
{[-0.49]}\end{array}$ & $\begin{array}{l}-0.0009 \\
{[-0.07]}\end{array}$ & $\begin{array}{l}-0.0027 \\
{[-0.93]}\end{array}$ & $\begin{array}{l}0.0010 * * * \\
{[5.29]}\end{array}$ \\
\hline Category Flow & $\begin{array}{l}0.0051^{* * *} \\
{[3.27]}\end{array}$ & $\begin{array}{l}0.0097 * * * \\
{[3.36]}\end{array}$ & $\begin{array}{l}0.0040 \\
{[1.36]}\end{array}$ & $\begin{array}{l}0.0013^{* * *} \\
{[3.83]}\end{array}$ \\
\hline Volatility & $\begin{array}{l}0.0072 \\
{[0.08]}\end{array}$ & $\begin{array}{l}-0.1307 \\
{[-0.85]}\end{array}$ & $\begin{array}{l}0.2065 \\
{[1.39]}\end{array}$ & $\begin{array}{l}-0.1993 \\
{[-1.39]}\end{array}$ \\
\hline Age & $\begin{array}{l}-0.0007 * * * \\
{[-12.56]}\end{array}$ & $\begin{array}{l}-0.0008 * * * \\
{[-7.04]}\end{array}$ & $\begin{array}{l}-0.0009 * * * \\
{[-8.59]}\end{array}$ & $\begin{array}{l}-0.0005^{* * *} \\
{[-10.50]}\end{array}$ \\
\hline Size & $\begin{array}{l}0.0014 * * * \\
{[2.28]}\end{array}$ & $\begin{array}{l}0.0065^{* * *} \\
{[4.88]}\end{array}$ & $\begin{array}{l}-0.0010 \\
{[-1.27]}\end{array}$ & $\begin{array}{l}0.0010^{* *} \\
{[1.90]}\end{array}$ \\
\hline Expenses & $\begin{array}{l}0.3091 * * * \\
{[2.28]}\end{array}$ & $\begin{array}{l}1.6952 * * * \\
{[5.24]}\end{array}$ & $\begin{array}{l}-0.2495^{*} \\
{[-1.65]}\end{array}$ & $\begin{array}{l}0.1152 \\
{[1.37]}\end{array}$ \\
\hline Total Fee & $\begin{array}{l}-0.0002 \\
{[-0.18]}\end{array}$ & $\begin{array}{l}-0.0002 \\
{[-0.12]}\end{array}$ & $\begin{array}{l}-0.0061^{* * *} \\
{[-2.33]}\end{array}$ & $\begin{array}{l}0.0089 * * * \\
{[6.95]}\end{array}$ \\
\hline Lag Flow & $\begin{array}{l}0.2141 * * * \\
{[12.02]}\end{array}$ & $\begin{array}{l}0.2477 * * * \\
{[5.95]}\end{array}$ & $\begin{array}{l}0.2038^{* * *} \\
{[7.11]}\end{array}$ & $\begin{array}{l}0.1904^{* * *} \\
{[8.39]}\end{array}$ \\
\hline Adj. $R^{2}$ & 0.22 & 0.24 & 0.25 & 0.21 \\
\hline
\end{tabular}


Figure 1. Histogram of the Value-weighted Disposition Spread

histogram of the value-weighted disposition spread

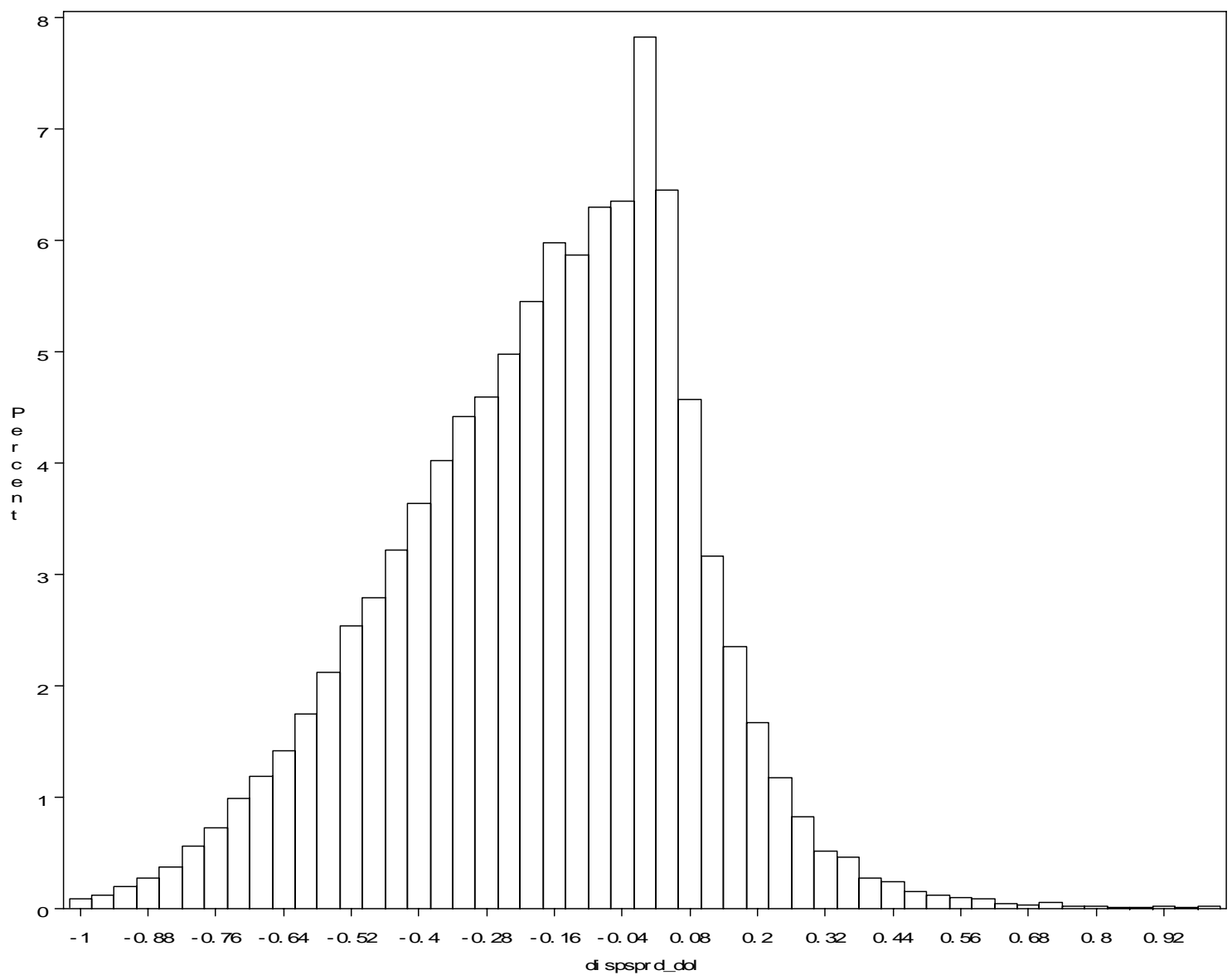


Figure 2. Histogram of the Disposition Spread Weighted by Number of Shares histogram of the disposition spread weighted by number of shares

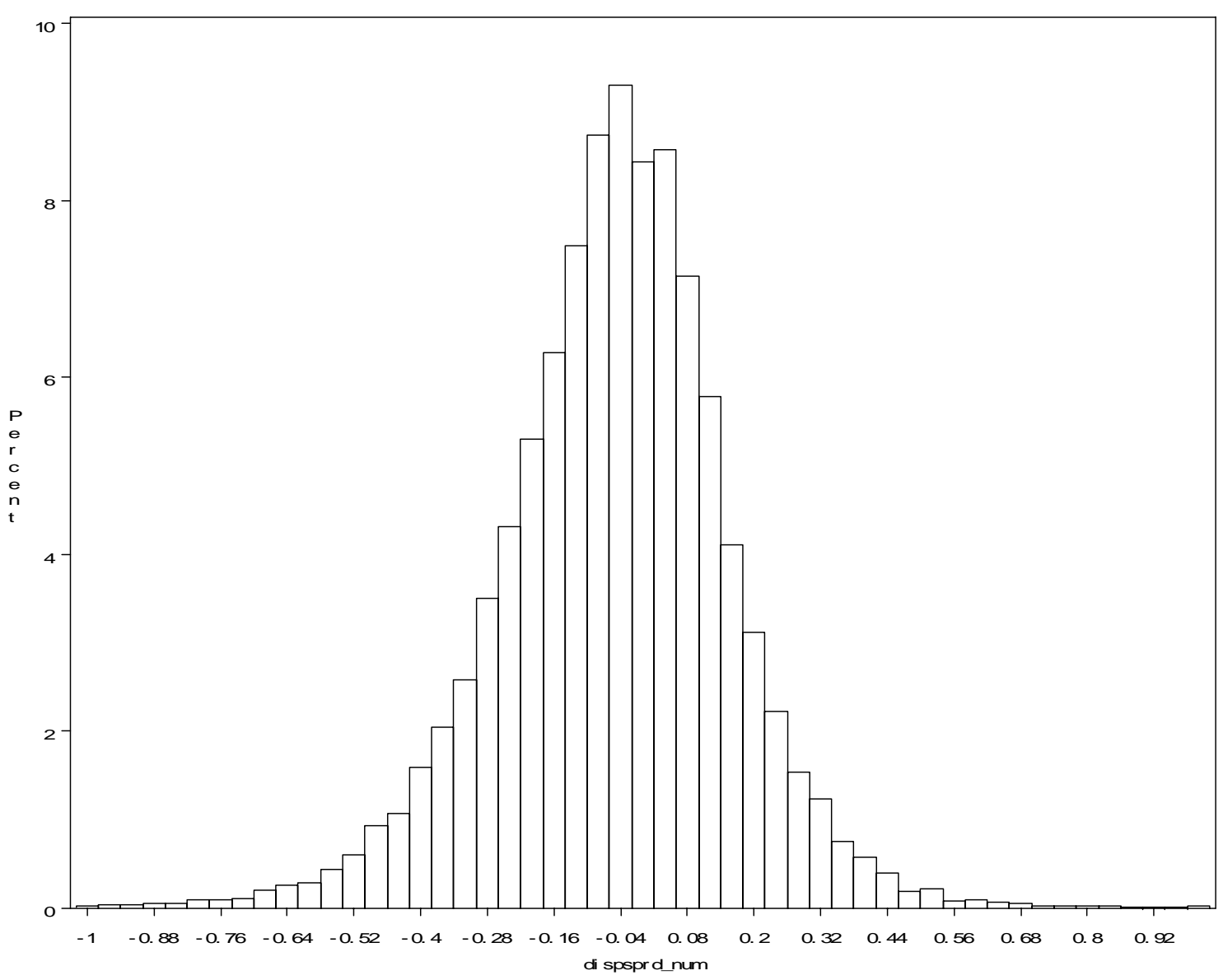




\section{VITA}

Zhaojin Xu was born in Nanjing, China. She earned her Bachelor's degree in Business (1999) from Nanjing Normal University, China, and received her MBA in Finance (2002) from State University of New York at Binghamton. During her studies in the Ph.D. program at Virginia Tech, she worked as a research assistant and taught Intermediate Financial Management, Investment Analysis \& Equity Markets, and Corporate Finance. In the academic year of 2005-2006, she worked as a full-time visiting lecturer at Radford University where she taught Introduction to Finance and Financial Markets \& Institutions at the undergraduate level. In addition, she taught one MBA section of Financial Management. She defended her dissertation on May 10, 2007. She is currently interested in research on empirical investments including mutual funds, return predictability, capital gains, and short sales. 